\title{
(On)gelijke toegang tot stage en werk van hbo'ers met een migratieachtergrond
}

Citation for published version (APA):

Klooster, E., Meng, C., Bles, P., Monker, D., \& Walz , G. (2020). (On)gelijke toegang tot stage en werk van hbo'ers met een migratieachtergrond: 'Hbo'ers, onderwijs en werkgevers over verklaringen en oplossingen'. ROA. ROA Reports No. 004 https://doi.org/10.26481/umarep.2020004

Document status and date:

Published: 06/10/2020

DOI:

10.26481/umarep.2020004

Document Version:

Publisher's PDF, also known as Version of record

\section{Please check the document version of this publication:}

- A submitted manuscript is the version of the article upon submission and before peer-review. There can be important differences between the submitted version and the official published version of record.

People interested in the research are advised to contact the author for the final version of the publication, or visit the DOI to the publisher's website.

- The final author version and the galley proof are versions of the publication after peer review.

- The final published version features the final layout of the paper including the volume, issue and page numbers.

Link to publication

\footnotetext{
General rights rights.

- You may freely distribute the URL identifying the publication in the public portal. please follow below link for the End User Agreement:

www.umlib.nl/taverne-license

Take down policy

If you believe that this document breaches copyright please contact us at:

repository@maastrichtuniversity.nl

providing details and we will investigate your claim.
}

Copyright and moral rights for the publications made accessible in the public portal are retained by the authors and/or other copyright owners and it is a condition of accessing publications that users recognise and abide by the legal requirements associated with these

- Users may download and print one copy of any publication from the public portal for the purpose of private study or research.

- You may not further distribute the material or use it for any profit-making activity or commercial gain

If the publication is distributed under the terms of Article $25 \mathrm{fa}$ of the Dutch Copyright Act, indicated by the "Taverne" license above, 
Maastricht University

\section{(On)gelijke toegang tot stage en werk van} hbo'ers met een migratieachtergrond 'Hbo'ers, onderwijs en werkgevers over verklaringen en oplossingen'

ROA / Klooster onderzoek \& advies:

Eva Klooster \& Christoph Meng

Per Bles

Dunja Monker

Gregor Walz

\section{ROA Rapport}

ROA-R-2020/4

Researchcentrum voor Onderwijs en Arbeidsmarkt | ROA Research Centre for Education and the Labour Market / ROA 


\section{Colofon}

(c) ROA 2020

Dit is een uitgave van het Researchcentrum voor Onderwijs en Arbeidsmarkt (ROA) in samenwerking met Klooster Onderzoek \& Advies. Niets uit deze uitgave mag op enige manier worden verveelvoudigd zonder voorafgaande schriftelijke toestemming van de directeur van het ROA.

\section{Researchcentrum voor Onderwijs en Arbeidsmarkt}

Postbus 616

6200 MD Maastricht

$\mathrm{T}+31433883647$

$\mathrm{F}+31433884914$

secretary-roa-sbe@maastrichtuniversity.nl

www.roa.nl

School of Business and Economics

Maastricht University

\section{Vormgeving}

ROA secretariaat, Maastricht

ISBN: 978-90-5321-600-2

ISSN: 2666-8858

Amsterdam, Maastricht oktober 2020 
'We hebben een missie nodig die uitgaat van verantwoordelijkheid voor het motiveren en het studie en stagesucces van hun studenten, geloof in hun kwaliteiten uitstralen richting bedrijven en voor ze op de bres springen als ze zich in een moeilijke situatie bevinden of ongelijk behandeld worden'. (docente rechten) 


\section{Inhoud}

$1 \quad$ Inleiding

1.1 Opbouw van rapport 4

2 (On)gelijke kansen: Kwantitatieve analyses 7

2.1 Kans op werkloosheid: HBO-Monitor 2014-2019 7

2.2 Kans op een kwalitatief goed baan 10

2.3 Een nadere analyse 13

2.4 Een nadere analyse: Kans op werk 14

2.5 Een nadere analyse: Kans op een kwalitatief goede baan 18

2.6 Een nadere analyse: Moeite bij vinden van stage 19

2.7 Een nadere analyse: Aanbod om na stage te blijven 20

2.8 Conclusies Kwantitatieve analyses 22

3 Ongelijke kansen: Kwalitatieve analyses 25

$4 \quad$ De context van de hbo-opleidingen en het werkveld 27

$\begin{array}{lll}4.1 & \text { De hbo-opleidingen } & 27\end{array}$

$\begin{array}{lll}4.2 & \text { Werkgevers } & 30\end{array}$

5 Oorzaken van (on)gelijke arbeidsmarktkansen 33

5.1 De hbo'ers aan het woord 33

5.1.1 Financiële situatie en werkervaring 34

5.1.2 De manier van netwerken 36

5.1.3 Ongelijke kansen bij (stage) bedrijven 38

5.1.4 (Zelf)vertrouwen en coping $\quad 41$

5.1.5 Ondersteuning opleiding 45

5.2 De onderwijsprofessionals aan het woord 46

5.2.1 Onderwijsprofessionals over (on)gelijke kansen 46

5.2.2 Toegang tot de arbeidsmarkt; kwetsbare groepen 48

5.2.3 Verschillen in stage- en netwerkervaring $\quad 49$

5.2.4 Verschillen in hulp vragen $\quad 50$

5.3 De werkgevers aan het woord 51

5.3.1 De werkgevers over (on)gelijke kansen 51

5.3.2 Discriminatie bij werving en selectie $\quad 52$

5.3.3 Wijze van sollicitatie $\quad 52$

5.4 Samenvatting 55 
6 Factoren die (gelijke) kansen op stage en werk versterken 57

6.1 De hbo'ers aan het woord 57

6.1.1 Docent-student contact 57

6.1.2 Ontmoeting met werkgevers tijdens studie 60

6.1.3 Presenteren en voor jezelf opkomen 61

6.2 De onderwijsprofessionals aan het woord 63

6.2.1 Meer persoonlijk contact met studenten 63

6.2.2 Maatwerk en extra ondersteuning bij studievertraging 64

6.2.3 Verbeteren aansluiting afstudeerstage bij werkveld 64

6.3 De werkgevers aan het woord 65

6.3.1 Arbeidsmarktrelevantie van hbo-opleidingen 65

6.3.2 Actievere matching vanuit de hogeschool 66

6.3.3 Intensievere sollicitatiebegeleiding en -oefening 67

6.3.4 Meer arbeidsmarktkennis bij hogescholen 68

$\begin{array}{ll}6.4 \text { Samenvatting } & 69\end{array}$

7 Conclusies en Aanbevelingen $\quad 73$

$\begin{array}{lll}7.1 & \text { Conclusies } & 74\end{array}$

7.2 Aanbevelingen gericht op bevorderen (gelijke) kansen 77

$\begin{array}{llr}8 & \text { Bibliografie } & 81\end{array}$

9 Bijlages 83

Bijlage 1: Kans op deelname aan vervolgonderzoek 83

Bijlage 2: Kans op werkloosheid: HBO-monitor en subsample 84

Bijlage 3: Empirische modellen $\quad 85$

Bijlage 4: Kans op werkloosheid: vervolgonderzoek $\quad 87$

Bijlage 5: Hoe vonden respondenten stage en werk? 90 


\section{Inleiding}

In Nederland studeren jaarlijks zo'n 74.000 studenten af bij een instelling voor het hoger beroepsonderwijs (hbo). Ondanks het feit dat het percentage hbo-gediplomeerden met een migratieachtergrond al jaren toeneemt, vertaalt dit zich nog niet in een gelijke arbeidsmarktpositie. In het najaar van 2019 is 6,6\% van de hbo-afgestudeerden met een niet-westerse migratieachtergrond en $5,2 \%$ met een westerse migratieachtergrond werkloos, terwijl 3,4\% van de hbo-afgestudeerden zonder migratieachtergrond werkloos is (HBO-Monitor 2019). Onderzoeken van het Research Centrum voor Onderwijs en Arbeidsmarkt (ROA) tonen bovendien aan dat de gemiddelde hbo'er met een migratieachtergrond er langer over doet om een stage of baan te bemachtigen, dan de hbo'er zonder migratieachtergrond (zie bijvoorbeeld ROA, 2016).

Er bestaat nog geen volledig beeld van de factoren die tijdens en kort na een hbo-studie bijdragen aan ongelijke arbeidsmarktkansen. In een eerder onderzoek van het ROA is geprobeerd het verschil tussen de werkloosheidspercentages van hbo-afgestudeerden met en zonder migratieachtergrond in de periode 2009-2014 te verklaren door individuele afgestudeerden te vergelijken (ROA, 2016, v.a. p.105). Een van de conclusies van dit onderzoek was dat de hogere werkloosheid onder jongeren met een migratieachtergrond slechts ten dele wordt verklaard door harde kenmerken als studierichting, niveau, opleiding ouders of afstudeercijfers. Uit publicaties van het Sociaal Cultureel Planbureau (SCP) bleek ongeveer hetzelfde (SCP, 2016; SCP, 2014; SCP, 2007). De onderzoeken van het SCP toonden aan dat de rol van discriminatie en minder efficiënt zoekgedrag moet worden meegenomen bij de verklaring van verschillen. Dat de voorkeuren van werkgevers bij sollicitaties mede verklarend zijn voor het werkloosheidsverschil werd opnieuw bevestigd in een onderzoek van Thijssen, Coenders \& Lancee (2019).

De hbo-instellingen trachten studenten te begeleiden naar goede en gelijke kansen op de arbeidsmarkt. De ministeries van Sociale Zaken en Werkgelegenheid (SZW) en Onderwijs, Cultuur en Wetenschap (OCW) beogen de hbo-instellingen hierbij te ondersteunen. Om die reden hebben de ministeries aan het Research Centrum voor Onderwijs en Arbeidsmarkt (ROA) en Klooster Onderzoek en Advies gevraagd op zoek te gaan naar het antwoord op de volgende onderzoeksvraag: :

\section{Welke factoren tijdens en kort na de studietijd in het hoger beroepsonderwijs zijn van invloed op het verschil in kans op werk na afronding van de studie tussen jongeren met een migratieachtergrond en autochtone jongeren?}


De onderzoekers hebben kwantitatieve en kwalitatieve onderzoeksmethoden ingezet om hbo-studenten, hbo-afgestudeerden, onderwijsprofessionals en professionals uit het werkveld te betrekken bij het onderzoek.

In het kader van het kwantitatieve deel van dit onderzoek is een vragenlijst uitgezet onder bijna 8.000 afgestudeerden van het hbo. Via een analyse van de antwoorden is getracht de verschillen tussen de groepen met en zonder migratieachtergrond wat hun arbeidsmarktsucces betreft nader te verklaren. De focus lag daarbij op de arbeidsmarktintrede en de arbeidsmarktsituatie anderhalf jaar na afstuderen.

De vragenlijst is ingevuld door hbo-afgestudeerden die eerder meewerkten aan de HBO-Monitor' 2014, 2015, 2016 en 2017. Zij hadden uitdrukkelijk toestemming gegeven om nog een keer benaderd te worden voor onderzoek door het ROA. Voordeel was dat over deze groep afgestudeerden al een breed palet aan informatie eerder was verzameld die in de aanvullende vragenlijst niet meer gevraagd hoefde te worden. Dit bood de mogelijkheid om in de aanvullende vragenlijst uitgebreid op een aantal thema's nader in te gaan. Alle informatie die op basis van de aanvullende vragenlijst verzameld werd, kon daarbij op respondentenniveau aan de informatie uit de eerder afgenomen HBO-Monitor-vragenlijst gekoppeld worden. Om de koppeling zo zuiver mogelijk te houden, gingen de aanvullende vragen over de situatie op de arbeidsmarkt anderhalf jaar na het afstuderen. Ze vielen dus samen met de afname van vragen over de situatie op de arbeidsmarkt in de initiële HBO-Monitor.

Het kwantitatieve deel van dit onderzoek biedt een landelijk beeld van de situatie kort na het afstuderen en een eerste set van aspecten welke a) in het algemeen de kans op werk na afstuderen beïnvloeden en b) het verschil in kans op werk tussen afgestudeerden met en zonder migratieachtergrond kunnen verklaren. Hiermee vormen de kwantitatieve analyses het vertrekpunt voor het kwalitatieve onderzoek.

Het kwalitatieve deel van het onderzoek is uitgevoerd bij de opleidingen HBO-Rechten, Bedrijfskunde en Commerciële Economie. De keuze voor deze opleidingsrichtingen houdt verband met de constatering dat het verschil in toegang groter is bij representatieve functies met veel klantcontact en een relatief krappe arbeidsmarkt (zie bijvoorbeeld ROA, 2016). De begeleidingscommissie waarin vijf hbo-instellingen waren vertegenwoordigd heeft de opleidingen benaderd met een verzoek om deelname.

Aan dit onderzoek hebben de Hogeschool van Amsterdam (HvA), De Haagse Hogeschool (HHS), Fontys Hogescholen en de Hogeschool Rotterdam (HR) hun medewerking verleend. De inbreng van deze opleidingen was van cruciaal belang. Wij bedanken deze hogescholen en de leden van de begeleidingscommissie voor hun bereidheid om mee te werken.

1 Voor verdere informatie betreffende de HBO-Monitor, zie www.hbomonitor.nl. 


\section{Enkele kanttekeningen vooraf:}

De constatering dat hbo-afgestudeerden met en zonder migratieachtergrond ongelijke toegang hebben tot de arbeidsmarkt vormde aanleiding voor dit onderzoek. Daaruit vloeit voort dat factoren zijn gezocht die de verschillen in arbeidsmarktkansen tussen hbo'ers met en zonder migratieachtergrond beïnvloeden. Dit type onderzoek maakt dat individuele verschillen en verschillen binnen groepen onbesproken blijven. Daarmee doen we geen recht aan de enorme veelzijdigheid en uiteenlopende identiteit van de individuele hbo'ers.

In het gehele onderzoek lag de focus op het verklaren van het verschil tussen afgestudeerden met een niet-westerse achtergrond en afgestudeerden zonder migratieachtergrond.

In het kwantitatieve deel van het rapport treft de lezer (in de figuren) ook vergelijkingen tussen de groep studenten met een niet-westerse achtergrond, studenten met een westerse migratieachtergrond en studenten zonder migratieachtergrond. In het kwalitatieve deel van het rapport staat achter de citaten of welke achtergrond de respondent heeft. In het belang van de leesbaarheid van dit tweede deel gebruiken we de term 'migratieachtergrond' voor studenten met een niet-westerse en westerse migratieachtergrond. .

Ten slotte. Wij hebben de hbo'ers die deelnamen aan dit onderzoek bevraagd voordat de hbo-opleidingen moesten stoppen met onderwijs op locatie vanwege de uitbraak van het coronavirus. Dit is van grote betekenis. De context waarbinnen de hbo'ers sinds voorjaar 2020 zoeken naar stage en werk is moeilijker geworden door afname van 'live' contact met docenten en vanwege de situatie op de arbeidsmarkt. Bekend is dat stages en flexibele banen overal onder druk staan. Het is aannemelijk dat verschillen in de arbeidspositie van hbo'ers met en zonder migratieachtergrond groter zijn geworden, zeker in de sectoren die het meest geraakt zijn.

Natuurlijk hebben ook de medewerkers op de hoge scholen en bedrijven te maken met de effecten van het coronavirus. Er zijn signalen dat een deel van de docenten de huidige werksituatie als (te) belastend ervaart. De aanbevelingen waarmee dit rapport eindigt houden geen rekening met de enorme uitdagingen waar de hbo'ers, de opleidingen en de bedrijven nu voor staan. Onze aanbevelingen zijn gebaseerd op de situatie voor corona en het is te verwachten dat het creëren van gelijke kansen op de stage- en arbeidsmarkt nu nog meer dan voor de corona-uitbraak om inzet vraagt van alle betrokkenen (studenten, onderwijs en werkveld) en op meerdere niveaus in de hbo-opleidingen.

De interviews zijn gehouden aan de hand van een itemlijst, zodat ruimte bestond voor eigen inbreng. Items die in ieder interview aan de orde kwamen waren: herkenning van en ervaringen met het vraagstuk ongelijke kansen, verklarende factoren (op basis 
van het kwantitatieve onderzoek en eigen verklaringen), factoren die bijdragen aan gelijke(re) kansen en knelpunten bij toetreding tot stage en werk. Om het vraagstuk van (on)gelijke toegang van meerdere kanten te bekijken is gesproken met hbo-studenten, afgestudeerden, onderwijsprofessionals en werkgevers.

\subsection{Opbouw van rapport}

Dit rapport is als volgt opgebouwd.

Hoofdstuk 2 vormt het kwantitatieve onderzoeksdeel. In dit hoofdstuk wordt getracht op basis van een vragenlijst onder afgestudeerden van het hbo de verschillen tussen de groepen met en zonder migratieachtergrond wat hun arbeidsmarktsucces betreft nader te verklaren. De focus ligt daarbij op de arbeidsmarktintrede en de arbeidsmarktsituatie anderhalf jaar na afstuderen.

De uitkomsten van het kwalitatieve onderzoek worden in Hoofdstuk 3 tot en met Hoofdstuk 6 gepresenteerd. Hoofdstuk 3 bevat een korte verantwoording van de data waarop de resultaten in dit deel van het onderzoek zijn gebaseerd.

Om de uitkomsten van de interviews te kunnen duiden, geven we in Hoofdstuk 4 allereerst een toelichting op de context van de geselecteerde hbo-opleidingen en hun werkveld. We beschrijven hoe de opleidingen hun studenten voorbereiden op de toegang tot de arbeidsmarkt en laten de werkgevers aan het woord komen over wervings- en selectieprocessen.

In Hoofdstuk 5 komen de geïnterviewde hbo'ers (hbo-studenten en afgestudeerden), onderwijsprofessionals en werkgevers aan het woord over ongelijke kansen op de arbeidsmarkt van hbo'ers met en zonder migratieachtergrond. ledere geïnterviewde is allereerst gevraagd naar de herkenning van het vraagstuk van ongelijke arbeidsmarktkansen. Daarna beschrijven we welke factoren volgens de geïnterviewden (mede) verklarend zijn voor de verschillen. In het tweede deel van Hoofdstuk 5 komen de onderwijsprofessionals en de werkgevers aan het woord aan de hand van dezelfde vragen.

De factoren die volgens de geïnterviewden (gelijke) kansen op stage en werk kunnen versterken staan centraal in Hoofdstuk 6. We starten dit hoofdstuk wederom met de ervaringen van hbo'ers (hbo-studenten en afgestudeerden) en hun suggesties voor gelijke arbeidsmarktkansen. Daarna beschrijven we wat de onderwijsprofessionals hierover hebben verteld en we sluiten wederom af met de voorstellen die zijn gedaan door professionals uit het werkveld van de opleidingen.

Hoofdstuk 7 sluit het rapport af. We vatten eerst de belangrijkste bevindingen uit het kwantitatieve en kwalitatieve deel samen en formuleren daarna op basis van de bevindingen aanbevelingen die kansrijk zijn bij het bevorderen van gelijke toegang tot de arbeidsmarkt van hbo'ers met en zonder migratieachtergrond. 
Deel A: Kwantitatieve Analyses 



\section{2 (On)gelijke kansen: Kwantitatieve analyses}

In het kader van het kwantitatieve deel van dit onderzoek hebben we een vragenlijst uitgezet onder afgestudeerden van het hbo. Met de antwoorden die we op deze vragen ontvingen, hebben we geprobeerd de verschillen tussen de groepen met en zonder migratieachtergrond nader te verklaren wat betreft hun arbeidsmarktsucces. De focus lag daarbij op de arbeidsmarktintrede en de arbeidsmarktsituatie anderhalf jaar na het afstuderen.

De groep hbo-afgestudeerden die benaderd werden, zijn respondenten van de HBO-Monitor (2014, 2015, 2016 en 2017) die nadrukkelijk toestemming hadden gegeven om nog een keer benaderd te worden voor onderzoek door het ROA. Het voordeel van het benaderen van deze groep afgestudeerden is dat over hen in het kader van de HBO-Monitor al een breed palet aan informatie was verzameld, die in de aanvullende vragenlijst niet meer gevraagd hoefde te worden.

Dit bood de mogelijkheid om in de aanvullende vragenlijst uitgebreid op een aantal thema's nader in te gaan. Alle informatie die op basis van de aanvullende vragenlijst verzameld werd, kon daarbij op respondentniveau gekoppeld worden aan de informatie uit de eerder afgenomen HBO-Monitor.

Dit hoofdstuk is als volgt opgebouwd: in de eerste paragraaf presenteren we een aantal beschrijvende figuren op basis van verschillende HBO-Monitor metingen over de kansen om werk te vinden. In de tweede paragraaf kijken we naar een aantal aspecten die betrekking hebben op de kwaliteit van het gevonden werk. In paragraaf 2.3 maken we dan de overstap van de algemene resultaten op basis van de HBO-Monitor naar het subsample van de respondenten die aan de vervolgstudie hebben deelgenomen. De paragrafen daarna presenteren we de analyses die uitgevoerd zijn op grond van de antwoorden op de aanvullende vragenlijst.

\subsection{Kans op werkloosheid: HBO-Monitor 2014-2019}

De HBO-Monitor metingen van de jaren 2014-2019 laten zien dat in al deze jaren de werkloosheid onder de afgestudeerden met een niet-westerse achtergrond anderhalf 
jaar na behalen van het diploma duidelijk hoger is dan de werkloosheid ${ }^{2}$ onder de afgestudeerden zonder migratieachtergrond. In het meetjaar 2008 (afgestudeerden van het studiejaar 2006-2007) was 5.2\% van de afgestudeerden met een niet-westerse migratieachtergrond werkloos tegenover $2.8 \%$ van de afgestudeerden zonder migratieachtergrond. In de economische crisisjaren 2010 tot en met 2014 is het werkloosheidspercentage onder de afgestudeerden met een niet-westerse migratieachtergrond rond de 14\%-15\%, terwijl onder de afgestudeerden zonder migratieachtergrond maximaal zo'n 7\% (2013) werkloos is. In de periode na 2014 daalt voor beide groepen afgestudeerden dankzij de aantrekkende economie de werkloosheid, om vanaf meetjaar 2018 te stabiliseren rond de $6.5 \%$ onder de afgestudeerden met een niet-westerse migratieachtergrond en 3.5\% onder de afgestudeerden zonder migratieachtergrond.

\section{Figuur 2.1}

Werkloosheid per meetjaar en etnische achtergrond

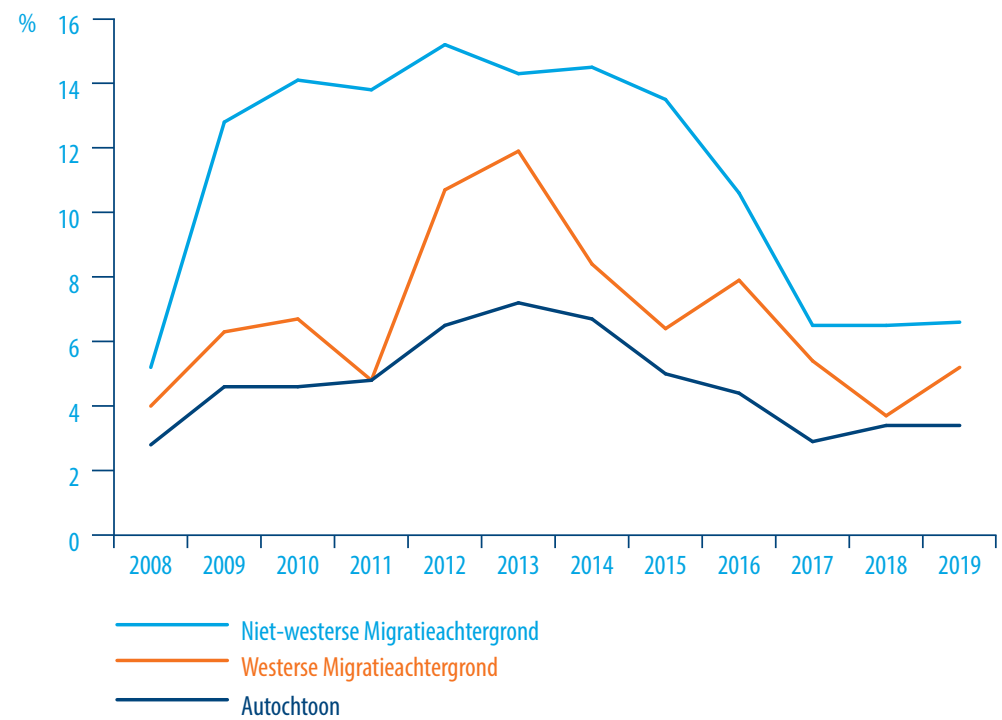

Bron: HBO-Monitor 2008-2019

Leggen we de focus op de recente meetjaren (2014-2019), dan zien we ook binnen de te onderscheiden opleidingssectoren in het hbo in de regel duidelijke verschillen tussen de groepen (zie figuur 2.2). Met uitzondering van de sector onderwijs, is het werkloosheidspercentage onder afgestudeerden met een niet-westerse migratieachtergrond in alle

2 Werkloosheid wordt in dit rapport gedefinieerd als 'niet werkzaam,',op zoek naar werk' en als hoofdactiviteit 'niet studerend'. Met andere woorden, jongeren die 1 uur per week werkzaam zijn behoren tot de werkzame beroepsbevolking en jongeren die op moment van enquête zichzelf als 'student' zien worden buiten de berekening gehouden. 
te onderscheiden opleidingssectoren aanzienlijk hoger dan onder de afgestudeerden zonder migratieachtergrond. Met andere woorden: het verschil in arbeidsmarktkansen doet zich niet alleen voor bij sectoren met in het algemeen relatief hoge werkloosheid (bijvoorbeeld economie), maar ook bij de afgestudeerden in sectoren die in de regel minder moeite hebben om aan het werk te komen (bijvoorbeeld techniek en gezondheidszorg).

\section{Figuur 2.2}

Werkloosheid per sector en etnische achtergrond (2014 - 2019)

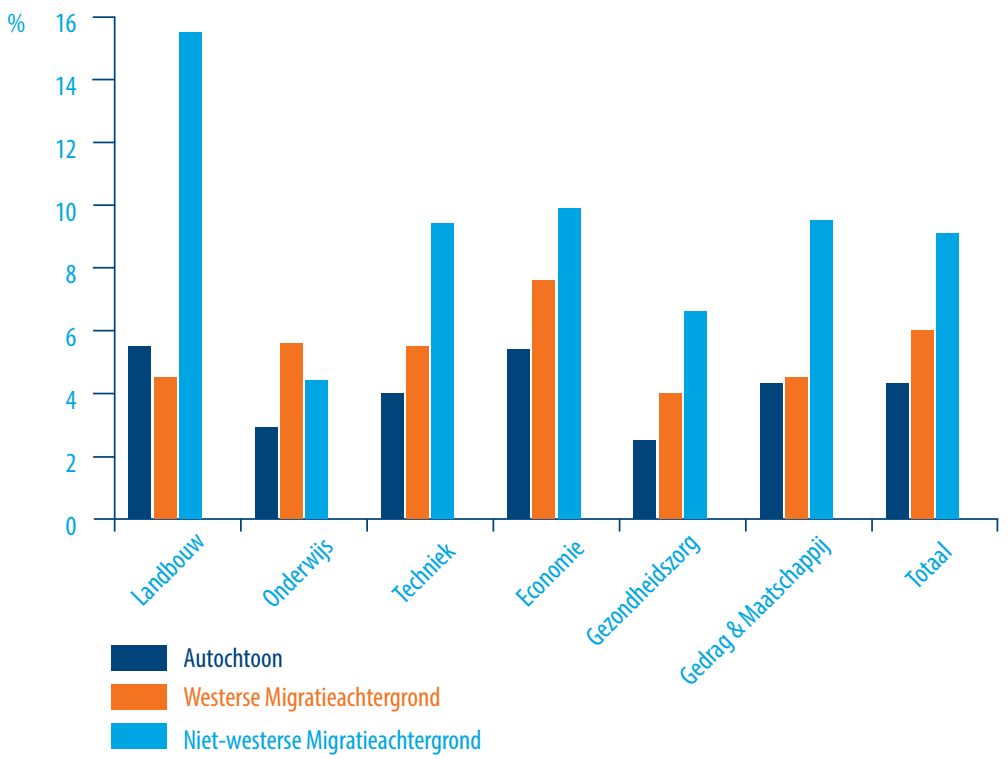

Bron: HBO-Monitor 2014-2019

Ook als we de cijfers analyseren en daarbij een onderscheid maken tussen mannelijke afgestudeerden en vrouwelijke afgestudeerden, zien we vergelijkbare beelden. Weliswaar is het verschil tussen de werkloosheid in de periode 2014-2019 onder de afgestudeerden met een niet-westerse migratieachtergrond en de afgestudeerden zonder migratieachtergrond onder de mannen iets groter (9,2\% versus 4,2\%) dan onder de vrouwen $(8,9 \%$ versus $4,3 \%)$, maar in beide gevallen is de werkloosheid onder de afgestudeerden met een niet-westerse migratieachtergrond minimaal twee keer zo hoog. 


\section{Box 2.1 Jongeren met een niet-westerse migratieachtergrond: een homogene groep?}

De hoofdanalyses in dit hoofdstuk maken geen verder onderscheid naar etnische herkomst binnen de groep van niet-westerse herkomst. Reden hiervoor is dat het aantal respondenten op basis van het aanvullende onderzoek te klein is om de groep met een niet-westerse migratieachtergrond nader onder te verdelen. Op basis van de HBO-Monitor is het echter wel mogelijk om werkloosheidspercentages te presenteren voor vier grotere groepen, namelijk de groep Turkse Nederlanders, Marokkaanse Nederlanders, Antilliaanse Nederlanders en Surinaamse Nederlanders. Figuur B2.1 laat zien dat de groep Antilliaanse Nederlanders met 5\% werkloosheid in de periode 2014-2019 het dichtst bij het werkloosheidspercentage van de groep zonder migratieachtergrond komt. Voor de andere drie groepen liggen de werkloosheidspercentages rond de $10 \%$ en daarmee meer dan twee keer zo hoog als onder de afgestudeerden zonder migratieachtergrond.

Figuur B2.1 Werkloosheidspercentage naar etnische herkomst (20142019)

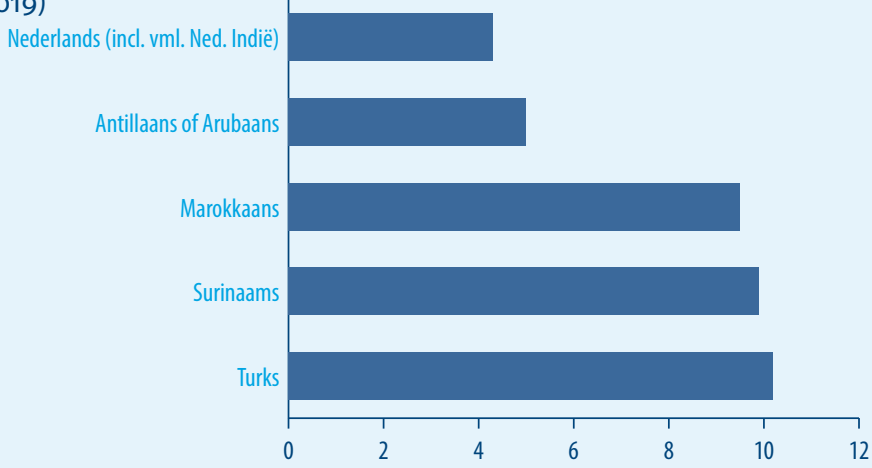

Bron: HBO-Monitor 2014-2019

\subsection{Kans op een kwalitatief goed baan}

Heeft de grotere kans op werkloosheid onder de afgestudeerden met een niet-westerse migratieachtergrond ook tot gevolg dat ze uiteindelijk in banen met een lagere kwaliteit terechtkomen? Hiervoor presenteren we vier indicatoren.

Ten eerste het percentage van de afgestudeerden dat in kleine deeltijdbanen (minder dan 12 uur per week werkzaam) terechtkomt. De 12-uurs grens is interessant omdat 
werkenden met een baan van minder dan 12 uur die actief op zoek waren naar ander werk (of meer uren werk in dezelfde functie) in Nederland tot 2015 als werkloos gedefinieerd werden. De cijfers van de HBO-Monitor in de periode 2014-2019 laten zien dat de kans om in een kleine deeltijdbaan werkzaam te zijn niet duidelijk verschilt tussen de drie groepen afgestudeerden. Over de zes jaren is $3 \%$ van de werkende afgestudeerden met een niet-westerse migratieachtergrond minder dan 12 uur werkzaam; dit is onder de groep met een westerse migratieachtergrond 3,3\% en onder de afgestudeerden zonder migratieachtergrond $2,5 \%$.

\section{Figuur 2.3}

Aansluiting functie - opleiding

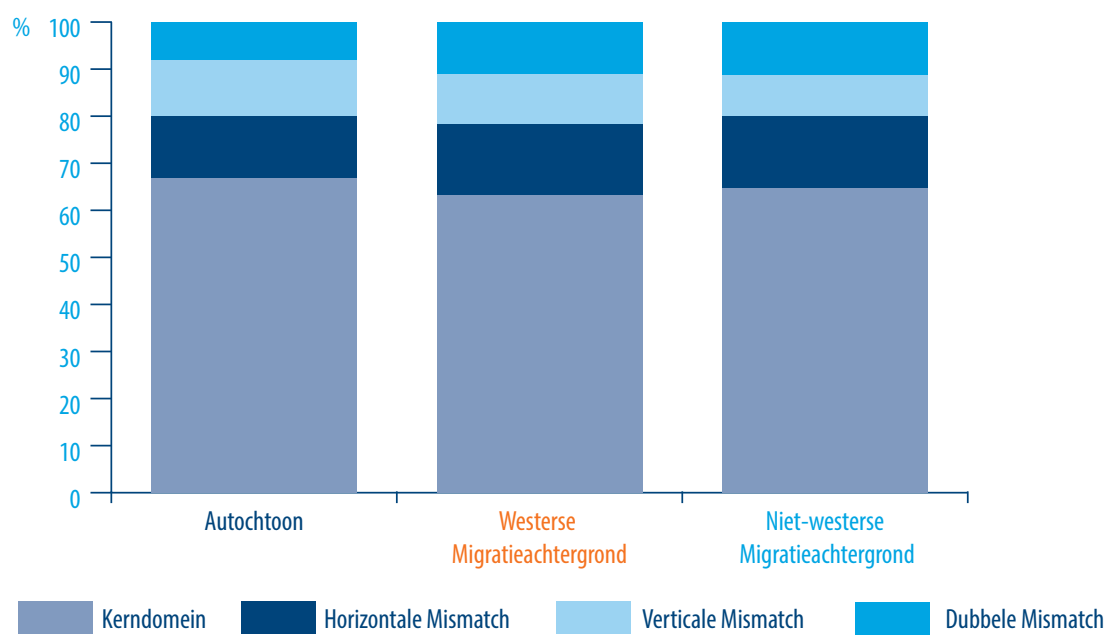

Bron: HBO-Monitor 2014-2019

Een tweede interessante indicator wat betreft de kwaliteit van de functie, is de aansluiting tussen de gevolgde hbo-opleiding en het gevonden werk. We kunnen daarbij zowel een verticale aansluiting als een horizontale aansluiting onderscheiden. Verticaal onderscheiden we functies die qua vereisten minimaal met het gevolgde opleidingsniveau overeenkomen en functies die een diploma lager dan een hbo-bachelor vereisen. Horizontaal onderscheiden we functies die rechtstreeks in het verlengde van de gevolgde opleidingsrichting liggen en functies die niet direct matchen met de gevolgde opleidingsrichting. Als we de verticale en de horizontale aansluiting combineren, kunnen we een viertal situaties beschrijven:

- Kerndomein: Zowel verticaal als horizontaal sluit de functie goed aan bij de gevolgde opleiding. 
- Horizontale mismatch: De functie sluit verticaal weliswaar goed aan bij de gevolgde opleiding maar niet wat betreft de richting.

- Verticale mismatch: De functie sluit weliswaar wat de richting betreft goed aan bij de gevolgde opleiding, maar zou ook met een lager dan hbo-bachelordiploma uitgevoerd kunnen worden.

- Dubbele mismatch: De functie sluit zowel wat het niveau als wat de richting betreft niet goed aan bij de gevolgde opleiding.

$65 \%$ van de werkende afgestudeerden met een niet-westerse migratieachtergrond heeft een functie die zowel qua richting als niveau goed aansluit bij de gevolgde opleiding (kerndomein). Dit is sterk vergelijkbaar met de cijfers onder de gediplomeerden van de andere twee groepen afgestudeerden. Van hen is namelijk $64 \%$ (westerse migratieachtergrond) en $68 \%$ (zonder migratieachtergrond) werkzaam in het kerndomein. ${ }^{3}$ Het aandeel waarbij sprake is van een horizontale mismatch, is $15 \%$ onder de werkende afgestudeerden met een niet-westerse migratieachtergrond en $13 \%$ onder de jongeren zonder migratieachtergrond. Samengenomen is daarmee zowel onder de jongeren met een niet-westerse migratieachtergrond als onder de jongeren zonder migratieachtergrond zo'n $80 \%$ in een functie werkzaam die qua niveau goed past bij de afgeronde hbo-opleiding.

Kijken we naar de werkenden die onder het eigen niveau werkzaam zijn, dan zien we dat er onder de afgestudeerden met een niet-westerse migratieachtergrond iets vaker (11\%) sprake is van een dubbele mismatch dan onder de jongeren zonder migratieachtergrond (8\%). Samenvattend lijkt het, op basis van deze cijfers, dat de hogere kans op werkloosheid zich niet slechts beperkt tot een slechtere aansluiting tussen gevolgde opleiding en gevonden werk.

Tot slot staan we nog stil bij de algemene tevredenheid van de werkende afgestudeerden met de functie en de subjectieve inschatting van de carrièreperspectieven in de huidige functie. In de periode 2014-2019 is van de werkende jongeren met een nietwesterse migratieachtergrond $61 \%$ (zeer) tevreden met de functie in het algemeen, wat lager is dan onder de werkende jongeren zonder migratieachtergrond (70\%).

Kijken we naar het andere einde van het spectrum, dan zien we dat $15 \%$ van de werkenden met een niet-westerse migratieachtergrond (zeer) ontevreden is en dat dit aandeel bij de werkenden zonder migratieachtergrond $11 \%$ is. Wat de subjectieve inschatting van de carrièreperspectieven betreft, zijn de cijfers relatief goed vergelijkbaar tussen de groepen. Van de werkenden met een niet-westerse migratieachtergrond is $57 \%$ van mening dat de huidige functie (heel) veel carrierperspectieven biedt (versus $61 \%$ onder de werkende afgestudeerden zonder migratieachtergrond) en $18 \%$ is wat dit

3 De cijfers per meetjaar laten wel zien dat in 2014, kort na de economische crisis, het aandeel werkende afgestudeerden met een niet-westerse migratieachtergrond dat in het kerndomein werkzaam is zo'n 8\%-punt lager lag dan onder de groep werkende afgestudeerden zonder migratieachtergrond (54\% versus 62\%). 
onderdeel betreft (zeer) ontevreden (versus 17\% onder de werkende afgestudeerden zonder migratieachtergrond).

\subsection{Een nadere analyse}

In het voorjaar van 2018 is een aanvullend onderzoek onder de eerdere respondenten van de HBO-Monitor uitgevoerd. Doelstelling was daarbij om gedetailleerde informatie te verzamelen over de ervaringen tijdens de studie (bijvoorbeeld gelopen stages, aan studie gerelateerde werkervaring, vrijwilligerswerk, bestuurlijke ervaring, zoekkanalen en persoonskenmerken). Hiermee wilden we, naast de eerder beschreven verschillen, vooral de verschillen tussen afgestudeerden met een niet-westerse migratieachtergrond en afgestudeerden zonder migratieachtergrond nader verklaren. Hiervoor zijn de respondenten van de HBO-Monitor 2014-2017, die destijds expliciet aangegeven hebben bereid te zijn om mee te doen aan vervolgonderzoek, uitgenodigd om aan een enquête deel te nemen. In totaal zijn 25.671 HBO-Monitor respondenten uitgenodigd en hebben 7.795 de enquête ingevuld (response van 30\%). Voordat we in paragraaf 2.4 de resultaten van de uitgevoerde analyses presenteren, is het belangrijk om eerst stil te staan bij mogelijke selectiviteit van de groep die aan de vervolgstudie heeft meegedaan. Immers, niet alle HBO-Monitorrespondenten hebben toestemming gegeven om nog een keer benaderd te worden en van degenen die nog een keer benaderd zijn, heeft 'slechts' $30 \%$ ook daadwerkelijk deelgenomen.

De analyse ${ }^{4}$ laat het volgende zien:

- De kans op deelname aan het vervolgonderzoek is kleiner onder de groep met een niet-westerse migratieachtergrond. Aangezien we in de navolgende analyses niet per definitie in de totale groep respondenten, maar in de verschillen tussen respondenten met en zonder migratieachtergrond geïnteresseerd zijn, hoeft dit niet direct een probleem te zijn.

- De kans op deelname aan het vervolgonderzoek neemt toe des te recenter de eerste deelname aan de HBO-Monitor was. Dat kan ermee samenhangen dat e-mailadressen van respondenten van de HBO-Monitor 2017 actueler zijn dan e-mailadressen van respondenten van bijvoorbeeld de HBO-Monitor2014.

- Er zijn geen grote regionale selectiviteitsproblemen geobserveerd.

- Vrouwen hebben vaker deelgenomen aan de aanvullende vragenlijst en met de toenemende leeftijd van de respondent neemt de kans toe om aan het vervolgonderzoek deelgenomen te hebben.

- Afgestudeerden van de opleidingssector economie zijn ondervertegenwoordigd in het sample dat aan het vervolgonderzoek heeft deelgenomen.

- Het gemiddelde afstudeercijfer van degenen die aan het vervolgonderzoek hebben deelgenomen ligt iets hoger dan onder degenen die niet deelgenomen hebben.

$4 \quad$ Zie tabel B.1 in Bijlage 1 voor de volledige resultaten. 
Naast de vraag of bepaalde groepen qua achtergrondkenmerken over- dan wel ondervertegenwoordigd zijn in de vervolgstudie, is het interessant nader stil te staan bij de vraag in hoeverre de werkloosheid onder bepaalde groepen van het subsample overeenkomt met de werkloosheid onder dezelfde type afgestudeerden van de HBO-Monitor. Tabel 2.1 presenteert voor de drie in dit rapport centraal staande groepen de werkloosheid onder de groep HBO-Monitor respondenten van 2014 tot 2017 en onder de groep die aan het vervolgonderzoek heeft deelgenomen.

Tabel 2.1

Werkloosheidspercentage in de HBO-Monitor en subsample

\begin{tabular}{|l|r|r|}
\hline & HBO-Monitor & Sub-sample \\
\hline Zonder migratieachtergrond & 4,8 & 4,5 \\
\hline Westerse migratieachtergrond & 7,1 & 5,8 \\
\hline Niet-westerse migratieachtergrond & 11,1 & 9,6 \\
\hline
\end{tabular}

Bron: HBO-Monitor 2014-2017

Tabel 2.1 laat zien dat de werkloosheid onder de respondenten van de vervolgstudie (subsample) iets lager ligt dan onder de respondenten van de HBO-Monitor in de jaren 2014-2017. Het verschil is daarbij in procentpunten het kleinst onder de respondenten zonder migratieachtergrond (0,3\%-punt) en het hoogst onder de respondenten met een niet-westerse migratieachtergrond (1,5\%-punt). Dat de groep respondenten met niet-westerse migratieachtergrond relatief gezien een licht succesvollere groep (wat het vinden van werk betreft) in het subsample is dan de groep zonder migratieachtergrond, is ook zichtbaar als we de kans op werkloosheid schatten op basis van de in de HBO-Monitor beschikbare informatie voor de gehele groep van HBO-Monitor respondenten en de groep die in het subsample valt (zie Tabel B.2 in Bijlage 2 voor de volledige resultaten). We dienen hiermee rekening te houden bij onze verdere discussie: deze schattingen zijn qua grootte een ondergrens. Wat de andere indicatoren betreft, zien we dat kwalitatief de resultaten in beide analyses sterk vergelijkbaar zijn, maar de indicatoren in de analyse van het subsample (deels door het kleinere aantal cases) enkele keren significantie verliezen.

\subsection{Een nadere analyse: Kans op werk}

De eerder gepresenteerde beschrijvende cijfers alsmede de eerste analyses laten duidelijk zien dat de kans op werkloosheid onder de groep afgestudeerden met niet-westerse migratieachtergrond groter is dan onder de groep afgestudeerden zonder migratieachtergrond. Op basis van de informatie verzameld in het vervolgonderzoek proberen we dit verschil nader te verklaren. We bouwen daarbij het model stapsgewijs op om de verklaringen voor het bestaande verschil in de analyse te kunnen onderscheiden. 
Figuur 2.4 presenteert voor elk van de onderscheiden modellen (zie Bijlage 3) de odds ratio (zie Box 2.2) voor de indicator 'niet-westerse migratieachtergrond'. De volledige resultaten van Model 20 worden in Bijlage 4 gepresenteerd.

\section{Figuur 2.4}

Odds ratio: Niet-westerse migratieachtergrond kans op werkloosheid

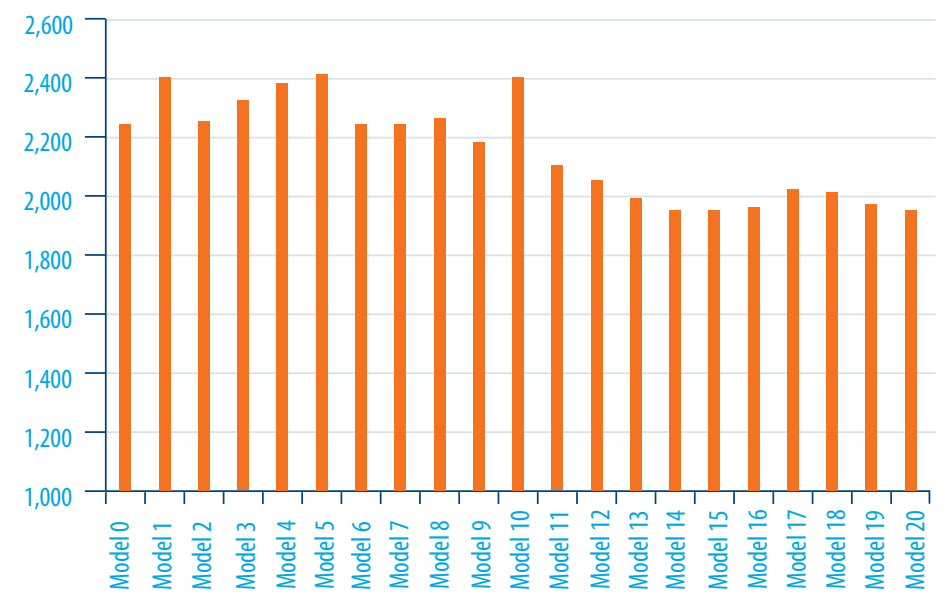

Bron: HBO Monitor, vervolgonderzoek (ROA)

Figuur 2.4 laat zien dat in ons basismodel de odds ratio 2.236 is en, net zoals in de beschrijvende analyses, de kans op werkloosheid in de groep met een niet-westerse migratieachtergrond 2.2 keer zo hoog is als in de groep zonder migratieachtergrond. Het toevoegen van de verschillende aanvullende indicatoren laat in het algemeen zien dat de odds ratio in eerste instantie fluctueert rond de $2.2 \mathrm{om}$ daarna te dalen tot net iets minder dan $2 \mathrm{om}$ in het laatste model uit te komen op 1.95 . 


\section{Box 2.2 Empirische analyses: Odds ratio}

Odds ratio:

In het hoofdstuk worden veelvoudig resultaten afkomstig van multivariate logistische regressies gepresenteerd. We presenteren daarbij in de regel de zogenaamde odds ratio. De odds ratio geeft de verhouding tussen een tweetal verhoudingen weer. Aan de hand van een fictief voorbeeld is het eenvoudig om te laten zien hoe de uitkomsten het beste geïnterpreteerd dienen te worden.

\begin{tabular}{lcc} 
& & \\
Groep 1 & Aantal werkzame & Aantal werkloze \\
Groep 2 & 90 & 10 \\
\hline
\end{tabular}

De odds ratio tussen groep 2 en groep 1 kan berekend worden als: $(20 / 80) /(10 / 90)=0.25 / 0.11=2.27$. Een odds ratio van boven $1 \mathrm{geeft}$ aan dat voor de gekozen groep (in dit geval groep 2) de kans om werkloos te zijn tegenover de kans om werkzaam te zijn hoger is dan deze verhouding in groep 1. De odds ratio tussen groep 1 en 2 kan berekend worden als: $(10 / 90) /(20 / 80)=0.11 / 0.25=0.44$.

Het toevoegen van persoonskenmerken in de modellen 1 tot en met 4 verhoogt de odds ratio en laat zien dat deze indicatoren geen verklaring kunnen bieden voor het oorspronkelijke verschil. Ook Model 5 verlaagt de odds ratio niet. Controlerend voor achtergrondkenmerken, het jaar van meting en de gevolgde opleiding voorafgaand aan de hbo-bachelor, is de relatieve kans op werkloosheid onder de groep met niet-westerse migratieachtergrond in onze steekproef dan ook 2,4 keer zo hoog dan onder de groep zonder migratieachtergrond.

In model 6 is een duidelijke daling zichtbaar van zo'n $23 \% .^{5}$ Deze daling wordt veroorzaakt door de studiekeuze in het hbo. Dit lijkt erop te duiden dat zo'n kwart van het verschil in de kans op werkloosheid verklaard kan worden door het feit dat jongeren met een niet-westerse migratieachtergrond andere opleidingskeuzes maken dan jongeren zonder migratieachtergrond en dat de gekozen opleidingen bij de groep jongeren met een niet-westerse migratieachtergrond minder arbeidsmarktkansen bieden.

Het toevoegen van de verschillende stage-indicatoren biedt geen verdere verklaring voor het verschil tussen de groep met een niet-westerse migratieachtergrond en de groep zonder migratieachtergrond. De enige indicator die een toevoeging aan de verklaring biedt, is de vraag of de respondent van het stagebedrijf een aanbod heeft gehad

5 De daling van 0.23 is berekend ten opzichte van de gewenste daling van 2.4 naar een odds ratio van 1. Bij een odds ratio van 1 is er immers net zoveel kans voor de beide groepen die vergeleken worden. 
om na het afronden van de bachelor bij het bedrijf te komen werken. Het toevoegen van deze indicator laat de odds ratio dalen van 2.24 naar 2.10 wat zo'n 8\% van het oorspronkelijke verschil verklaart.

Ook het toevoegen van (studie-gerelateerde) werkervaring en vrijwilligerswerk kan het verschil verder verklaren (zie model 12 tot en met 14). In model 14 ligt de odds ratio dan ook voor het eerst onder $2(1,945)$. De resterende modellen voegen qua verklaring verder niet direct iets toe en de odds ratio blijft dan ook tot en met model 20 tussen de 1,945 en 2,016 schommelen.

Samenvattend kunnen we stellen:

1. Dat er hoofdzakelijk drie indicatoren zijn die aan de verklaring van het verschil een bijdrage kunnen leveren, namelijk studiekeuze, werkervaring opgedaan tijdens de studie en de kans om na het volgen van een stage een aanbod van het bedrijf te hebben ontvangen.

2. Dat er ondanks het toevoegen van een groot aantal indicatoren die een breed scala van mogelijke verklaringen kunnen bieden, de kans op werkloosheid binnen de groep afgestudeerden met een niet-westerse migratieachtergrond nog steeds ongeveer twee keer zo hoog is als binnen de groep zonder migratieachtergrond.

\section{Box 2.3 Kans op werk: algemene factoren}

Naast het feit dat de indicatoren gekozen zijn om het verschil in de kans op werkloosheid tussen de groep afgestudeerden met een nietwesterse migratieachtergrond en de groep zonder migratieachtergrond nader te verklaren, is het natuurlijk interessant om te zien in hoeverre de indicatoren zelf een voorspellende waarde voor de kans op werkloosheid kennen. In deze tekst box presenteren we op basis van het meest uitgebreide model een aantal opvallende resultaten:

- Niet verrassend vinden we dat de werkloosheid tussen 2014 en 2017 daalt en dat zeker in het meetjaar 2017 de arbeidsmarkt in het algemeen beter is dan in de jaren ervoor.

- Afgestudeerden woonachtig in de regio Oost kennen een minder goede arbeidsmarktpostitie dan degenen die in de regio West wonen.

- Het type stage dat men heeft gelopen (oriëntatie stage, werkervaringsstage of onderzoeksstage) maakt voor het uiteindelijk vinden van een baan na het afstuderen geen verschil.

- Zowel studiegerelateerde werkervaring (buiten de stage om) als nietstudiegerelateerde werkervaring verlaagt de kans op werkloosheid.

- Een hoge score of de psychologische constructen self-efficacy en drive verlaagd de kans op werkloosheid. 


\subsection{Een nadere analyse: Kans op een kwalitatief goede baan}

Zoals eerder opgemerkt is het vinden van een baan na het afstuderen een eerste stap. Een tweede, en voor het verdere verloop van een carrière zeker zo belangrijke stap is dat het gevonden werk van goede kwaliteit is. Kwaliteit van de gevonden functie kan natuurlijk op verschillende manieren vastgesteld worden. In het voorliggende rapport doen we dit aan de hand van een vijftal indicatoren. In eerste instantie kijken we naar het aantal uren dat de respondent werkzaam is en dan specifiek naar de vraag of hij of zij een functie voor minimaal 12 uur vervult. In tweede instantie kijken we naar de aansluiting tussen de gevolgde opleiding en het gevonden werk. We doen dit door te analyseren of er bij de gevonden functie sprake is van een verticale mismatch (werkzaam onder hbo-bachelor niveau) of een dubbele mismatch (functie sluit zowel qua niveau als qua richting niet bij de gevolgde opleiding aan). Tot slot analyseren we nog de tevredenheid over de gevonden functie in het algemeen en over de carrièreperspectieven. Voor alle vijf indicatoren hebben we eerder vastgesteld dat deze in de regel iets minder gunstig uitpakken voor de groep afgestudeerden met een niet-westerse migratieachtergrond dan voor de groep afgestudeerden zonder migratieachtergrond. De vraag is nu of dit verschil ook significant van nul verschilt en of de eerder besproken indicatoren, zoals stage(s) etc. een mogelijk verschil nader kunnen verklaren.

Tabel 2.2 presenteert voor de vijf analyses het basismodel met daarin slechts opgenomen een dummy voor de groep afgestudeerden met een niet-westerse migratieachtergrond.

Tabel 2.2

odds ratio's niet-westerse migratieachtergrond

\begin{tabular}{|c|c|c|c|c|c|}
\hline & $\begin{array}{r}\text { Maximaal } 11 \\
\text { uur werkzaam }\end{array}$ & $\begin{array}{r}\text { Onder niveau } \\
\text { werkzaam }\end{array}$ & $\begin{array}{l}\text { Dubbele } \\
\text { mismatch }\end{array}$ & $\begin{array}{r}\text { Niet tevreden } \\
\text { met functie }\end{array}$ & $\begin{array}{l}\text { Niet tevreden } \\
\text { met carrière- } \\
\text { perspectieven }\end{array}$ \\
\hline $\begin{array}{l}\text { Niet-westerse } \\
\text { migratieachtergrond }\end{array}$ & 1.43 & 1.12 & 1.09 & $1.68^{* * *}$ & $1.38^{* *}$ \\
\hline
\end{tabular}

Tabel 2.2 laat zien dat in het basismodel een tweetal indicatoren ook daadwerkelijk een nadelige situatie van de groep met een niet-westerse migratieachtergrond laat zien, namelijk de kans dat men niet (heel) erg tevreden is met de gevonden functie in het algemeen en de kans dat men niet (heel) erg tevreden is met de geboden carrièreperspectieven. In tegenstelling tot deze twee meer subjectieve indicatoren, zien we wat de meer objectieve indicatoren betreft geen significant verschil. Analyseren we de twee subjectieve indicatoren verder, dan vinden we de volgende uitkomsten:

- Carrièreperspectieven: het in eerste instantie gevonden nadeel verliest na toevoeging van verdere achtergrondkenmerken van de respondent (en dan vooral het toevoegen van het geslacht en de leeftijd) zijn significantie. 
- Algemene tevredenheid: het in eerste instantie gevonden nadeel slinkt aanzienlijk door het toevoegen van de gevolgde opleidingsrichting in het hbo en verliest zijn significantie na het toevoegen van de vraag of men van het bedrijf waar men een stage gelopen heeft een aanbod heeft ontvangen om na het behalen van het diploma te komen werken.

Samenvattend kunnen we vaststellen dat, als de afgestudeerden werk hebben gevonden, we geen duidelijke verschillen in het gevonden werk tussen de groep met een niet-westerse migratieachtergrond en de groep zonder migratieachtergrond kunnen vinden.

\subsection{Een nadere analyse: Moeite bij vinden van stage}

Solliciteren na het behalen van het bachelordiploma is natuurlijk niet het eerste contact dat studenten van het hbo opdoen met bedrijven. Immers, zoals in de vorige paragraaf al besproken, is het lopen van stage(s) tijdens de opleiding dan wel het opdoen van andere werkervaring een belangrijk onderdeel van een bacheloropleiding. In deze paragraaf staan we dan ook stil bij de vraag of de respondenten met een niet-westerse migratieachtergrond tijdens de studie bij het vinden van een stageplek vergelijkbare problemen ondervonden. In tegenstelling tot de analyses op de kans op vinden van werk, gaat het bij deze analyses echter niet om het wel of niet vinden van een stageplek (de groep ondervraagden heeft immers de hbo-opleiding succesvol afgerond en heeft daarmee, zover dit verplicht was, ook minimaal één stagegelopen), maar om de vraag hoe vaak men diende te solliciteren voordat men een stageplek vond. De navolgende analyses laten, vergelijkbaar met de kans op werkloosheid, de odds ratio zien van de kans dat respondenten met een niet-westerse migratieachtergrond meer dan vijf keer diende te solliciteren.

Model o is wederom het basismodel waarin we slechts een tweetal variabelen opnemen, namelijk een dummy voor de groep respondenten met een westerse migratieachtergrond en een dummy voor de groep respondenten met een niet-westerse migratieachtergrond.

In model 1 tot en met model 4 voegen we stapsgewijs achtergrondkenmerken van de respondent toe aan het basismodel. In model 1 is dit het jaar waarin de HBO-Monitor meting heeft plaatsgevonden alsmede de regio waarin de respondent op moment van afname van de HBO-Monitor woonachtig is. In model 2 zijn dit het geslacht en de leeftijd, in model 3 het opleidingsniveau van de ouders en in model 4 indicatoren over de mate van het gebruik van de Nederlandse taal of andere talen in de communicatie in familieverband en met vrienden. 
In model 5 (gevolgde vooropleiding voorafgaand aan hbo-bachelor) en in model 6 (gevolgde opleidingssector en afstudeercijfer in hbo) analyseren we in hoeverre verschillende studiekeuzes en onderwijsloopbanen een verklaring kunnen bieden.

\section{Figuur 2.5}

Odds ratio: Niet-westerse migratieachtergrond kans op minimaal 6 keer solliciteren voor stage

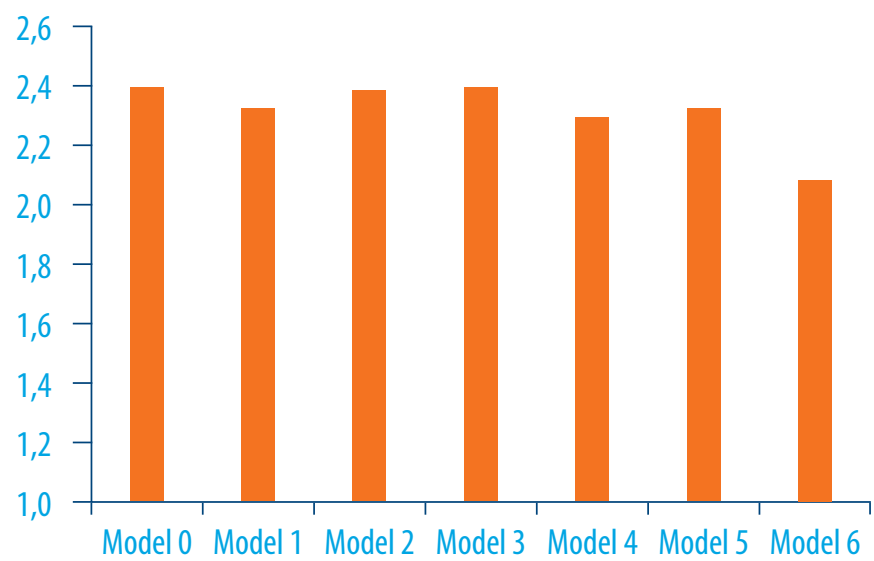

Bron: HBO Monitor, vervolgonderzoek (ROA)

De resultaten in Figuur 2.5 laten een interessant beeld zien. Tussen model o en model 5 is er relatief weinig verschil te vinden. De kans dat een student minimaal zes keer diende te solliciteren is in de groep studenten met een niet-westerse migratieachtergrond zo'n 2,4 keer zo hoog als in de groep studenten zonder migratieachtergrond. Het toevoegen van de gevolgde studierichting laat deze relatieve kans dalen naar 2,08. De resultaten zijn hier dan ook sterk vergelijkbaar met de resultaten die we in onze analyses op de kans op het vinden van werk na afronden van de bacheloropleiding hebben gevonden. De studierichting kan weliswaar een deel van het verschil verklaren, maar er blijft ook dit keer ongeveer een factor 2 over.

\subsection{Een nadere analyse: Aanbod om na stage te blijven}

Vergelijkbaar met de vraag of het nadeel dat de afgestudeerden bij het vinden van werk hebben zich ook vertaalt in een post-entry nadeel (een kwalitatief mindere baan), kunnen we de vraag stellen of de moeite die de studenten met een niet-westerse migratieachtergrond ervaren bij het vinden van stage zich vertaalt in mindere kansen om van het stagebedrijf een aanbod te krijgen om na het afstuderen te komen werken. Deze indicator zegt natuurlijk niet direct iets over de kwaliteit van de stage, maar gezien het feit dat deze indicator een belangrijke voorspeller is of men anderhalf jaar na het behalen van het diploma werk heeft of niet, is het wel interessant om na te gaan of jongeren met 
een niet-westerse migratieachtergrond in dezelfde mate een aanbod hebben gekregen als jongeren zonder een migratieachtergrond.

Vergelijkbaar met de eerdere analyses bouwen we het model stapsgewijs op. Model o is wederom het basismodel waarin we slechts een tweetal variabelen opnemen, namelijk een dummy voor de groep respondenten met een westerse migratieachtergrond en een dummy voor de groep respondenten met een niet-westerse migratieachtergrond. Model 1 tot en met model 6 zijn op dezelfde manier opgebouwd als de modellen voor het aantal sollicitaties dat nodig was om de stageplek te vinden.

Tot slot voegen model 7 tot en met model 10 indicatoren met betrekking tot de gevolgde stages tijdens de hbo-bachelor toe zoals het aantal stages en de totale stageduur (model 7), het type stage in model 8 (oriëntatie stage, werkervaringsstage, onderzoeksstage), of men zich lid voelde van het stagebedrijf en of men de stage-ervaring goed kon delen tijdens en na de lessen (model 9) en tot slot de etnische samenstelling van het stagebedrijf (model 10).

\section{Figuur 2.6}

Odds ratio: : Niet-westerse migratieachtergrond kans op geen aanbod om bij stagebedrijf te komen werken

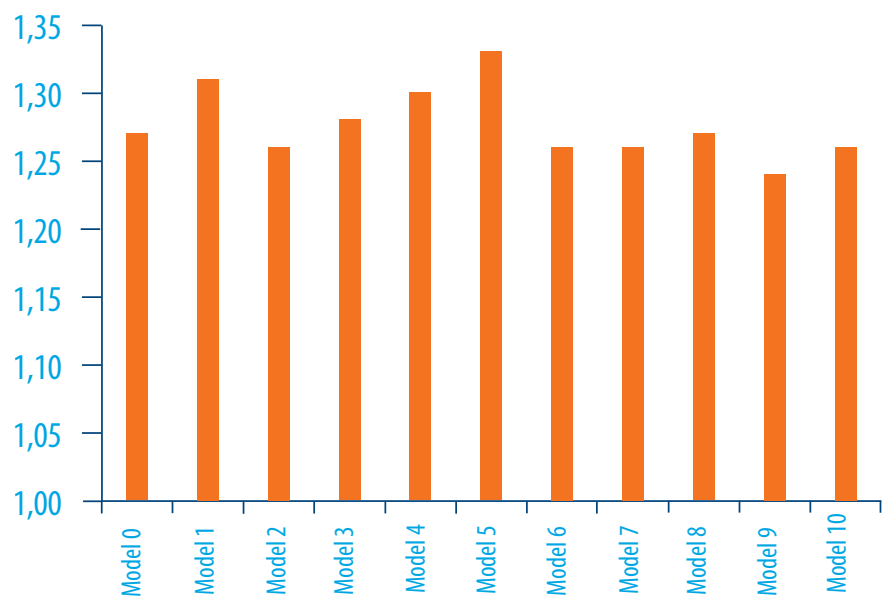

Bron: HBO Monitor, vervolgonderzoek (ROA)

Figuur 2.6 laat zien dat de odds ratio in alle modellen rond de 1,25 ligt, wat indiceert dat studenten met een niet-westerse migratieachtergrond een iets hogere kans hebben dat ze geen aanbod ontvangen. Echter, alleen in de modellen o, 2 en 3 kan een significant nadeel voor de groep met een niet-westerse migratieachtergrond vastgesteld worden. We dienen dan ook te concluderen dat, vergelijkbaar met de arbeidsmarktanalyses na behalen van het diploma, het nadeel zich vooral voordoet bij het vinden van een stage- 
plek en niet bij de kans om, als men een stageplek heeft gevonden, bij het stagebedrijf te mogen blijven werken.

\subsection{Conclusies Kwantitatieve analyses}

De in dit hoofdstuk gepresenteerde kwantitatieve analyses op basis van een uitgebreid databestand met de antwoorden van bijna 8.000 hbo-alumni laten een aantal belangrijke bevindingen zien.

\section{Pre-entry en/of post-entry nadeel}

De analyses van zowel de stages tijdens de opleiding alsmede de eerste baan na het afstuderen laten zien dat het nadeel dat jongeren met een niet-westerse migratieachtergrond ervaren vooral zichtbaar is tijdens de pre-entry fase. Met andere woorden:

- Jongeren met een niet-westerse migratieachtergrond hebben meer moeite om een stageplek te vinden en meer moeite om na het afstuderen werk te vinden.

- Dit nadeel vertaalt zich niet per se in een kwalitatief matigere eerste baan na het afstuderen.

\section{Algemene succesfactoren voor werk na afstuderen}

De kans op werk na het afstuderen wordt voor hbo-ers door een aantal algemene factoren bepaald:

- De kans is afhankelijk van de algemene economische situatie.

- De kans is afhankelijk van de gekozen studie.

- Werkervaring tijdens de studie, en met name studie gerelateerde werkervaring tijdens de studie, verhoogt de kans op het vinden van werk na het afstuderen.

- Een hoge score of de psychologische constructen self-efficacy en drive verhogen de kans op het vinden van werk na het afstuderen.

Verklarende factoren voor nadeel van jongeren met een niet-westerse migratieachtergrond

De analyses laten zien dat er een tweetal aspecten zijn die een (klein) deel van het nadeel kunnen verklaren:

- Studiekeuze: jongeren met een niet-westerse migratieachtergrond volgen relatief vaker een studie met matigere algemene arbeidsmarktperspectieven.

- Relevante werkervaring tijdens studie: jongeren met een niet-westerse migratieachtergrond hebben minder vaak relevante, dat wil zeggen aan de studie gerelateerde, werkervaring opgedaan. 
De hier gepresenteerde conclusies op basis van de kwantitatieve analyses vormen het startpunt van de kwalitatieve analyses die we in de volgende hoofdstukken presenteren. 
Deel B: Kwalitatieve Analyses 


\section{Ongelijke kansen: Kwalitatieve analyses}

Het kwalitatieve deel van het onderzoek is uitgevoerd bij de opleidingen $\mathrm{HBO}$-Rechten, Bedrijfskunde en Commerciële Economie ${ }^{6}$. De keuze voor specifiek deze opleidingsrichtingen is gemaakt in overleg met de begeleidingscommissie. Er is bij de keuze rekening gehouden met het feit dat het verschil in toegang groter is bij afgestudeerden van opleidingsrichtingen die te maken hebben met een krappe(re) arbeidsmarkt, waar ook deze opleidingsrichtingen mee te maken hebben (zie bijvoorbeeld ROA, 2016)

De interviews zijn gehouden aan de hand van itemlijsten, waarbij veel ruimte bestond voor eigen inbreng en oplossingen van de geïnterviewden. Items die in ieder interview aan de orde kwamen waren: herkenning van en ervaringen met het vraagstuk ongelijke kansen, knelpunten bij de toetreding tot stage en werk, verklarende factoren voor knelpunten en factoren die bijdragen aan gelijke(re) kansen. Om het vraagstuk van (on) gelijke toegang van meerdere kanten te kunnen bekijken, is gesproken met verschillende groepen direct betrokkenen, namelijk: studenten, alumni, onderwijsprofessionals en professionals uit beroepenveld.

In totaal hebben 75 respondenten aan het kwalitatieve deel van het onderzoek deelgenomen. De respondentengroep is als volgt opgebouwd:

- 42 hbo-studenten en alumni: waarvan 31 met een migratieachtergrond (Marokkaans, Turks, Turks-Koerdisch, Portugees-Koerdisch, Antilliaans, Surinaams, Congolees, Pools)

- 22 medewerkers van hbo-opleidingen; docenten, stagecoördinatoren, coördinatoren langstudeerders, opleidingsmanagers

- 11 vertegenwoordigers van (stage)bedrijven; HR-medewerkers, eigenaren en directieleden

Met de meerderheid van de respondenten (65) hielden de onderzoekers individuele face-to-face gesprekken. Met zes onderwijsprofessionals spraken de onderzoekers in groepsgesprekken. Vier respondenten vulden een vragenlijst in.

6 Het onderzoek heeft plaatsgevonden op vijf hbo-locaties, waarvan twee economische opleidingen en drie juridische opleidingen. Voor de leesbaarheid gebruiken we in de tekst 'opleidingen', daar waar eigenlijk 'opleidingslocaties' moet staan. 
Er is voor gekozen om alleen studenten te werven die met de laatste twee jaar van hun studie bezig zijn, zodat alle respondenten ervaring hadden met de toegang naar stage en/of werk. Er zijn verschillende methoden ingezet om studenten en alumni te werven. De onderzoekers vroegen in eerste instantie aan opleidingsmanagers en (bij stage) betrokken onderwijsprofessionals om studenten en alumni te benaderen. Hiervoor werden (persoonlijke) mails en Linkedln-groepen gebruikt. De onderzoekers hebben zelf ook oproepen gedaan via Linkedln. Daarnaast werden de alumni aangeschreven die eerder aan het ROA-onderzoek hadden deelgenomen.

De onderwijsprofessionals zijn geworven via leden van de begeleidingscommissie ${ }^{7}$ en via opleidings- en teammanagers van de deelnemende opleidingen. Er is gezocht naar professionals met veel contact met studenten en/of de voorbereiding op stage en werk. Bij de werving van werkgevers was ervaring met hbo-studenten en afgestudeerden van de deelnemende opleidingen een voorwaarde. Met circa de helft van de werkgevers zijn de onderzoekers in contact gekomen via de hogescholen, de overige werkgevers zijn via eigen netwerkcontacten geworven. Er is gelet op een gelijke verdeling van werkgevers uit de publieke en de private sector.

7 In de begeleidingscommissie zaten vertegenwoordigers van in totaal zes hbo-opleidingen, de raad van hogescholen en het ministerie van SZW en OCW. 


\section{De context van de hbo-opleidingen en het werkveld}

Om de uitkomsten van de enquête en interviews te kunnen duiden, geven we de lezer in dit hoofdstuk allereerst een toelichting op de context van de hbo-opleidingen en het werkveld. In paragraaf 4.1 beschrijven we hoe de opleidingen hun studenten voorbereiden op de toegang tot de arbeidsmarkt. In paragraaf 4.2 komen de werkgevers aan het woord over hun wervings- en selectieprocessen.

\subsection{De hbo-opleidingen}

\section{Voorbereiding op kiezen en solliciteren}

In de praktijk van de opleidingen bestaat de voorbereiding op de arbeidsmarkt voor een belangrijk deel uit (de voorbereiding op) de stage. Alle opleidingen kennen een studieonderdeel waarin de studenten worden voorbereid op de toegang tot de arbeidsmarkt, maar dan in het kader van stagevoorbereiding. Los van kleine verschillen tussen de opleidingen, bestaat dit onderdeel meestal uit minimaal een training solliciteren, met aandacht voor het schrijven van een brief met $C V$ en het oefenen van een sollicitatiegesprek, vaak met gebruik van een rollenspel. Dit studieonderdeel omvat meestal enkele lessen/studiepunten.

De oriëntatie op het werkveld en de begeleiding van het keuzeproces van de student, is bij de meeste opleidingen belegd bij de studiebegeleiders of studieloopbaancoaches. Zij besteden onder andere aandacht aan 'personal branding' in een Persoonlijke Leerlijn (PLO) of Studieloopbaanbegeleiding (SLB). Om studenten te laten reflecteren op de eigen talenten en keuzen komen de vragen 'Wie ben ik, wat kan ik, wat wil ik?' met regelmaat terug. In de praktijk van studiebegeleiding wordt ook wel gesproken over'de drie grote vragen'. Deze lessen maken onderdeel uit van het curriculum en worden door alle studenten in de regel op hetzelfde moment gevolgd gedurende hun studie. Een aantal opleidingen biedt daarnaast ook extra, facultatieve, workshops gericht op beroepsorientatie en de arbeidsmarkt.

\section{Voorbereiding op zoeken}

Wat betreft de opleidingen zijn 'zelfstandigheid, eigen verantwoordelijkheid en eigen initiatief' kenmerken van studeren op hbo-niveau en daaruit volgt dat hbo-studenten in principe zelfstandig stages moeten vinden. Ter ondersteuning van het zoekproces bieden de opleidingen hulp via een intern stagebureau, een stagecoördinator en/ of stagebord. Ook het organiseren van dagen voor werkgevers op de opleiding (zoals 
speeddates) behoort tot de ondersteuning die opleidingen bieden. Na de volgende paragraaf gaan we hier verder op in.

\section{Verschillende stages}

De opleidingen kennen meerdere stageperiodes die ieder een ander doel hebben. De meeste opleidingen hebben een stageperiode in het derde jaar en één helemaal aan het einde van de opleiding. ${ }^{8}$ De stage in het derde jaar is gericht op het meewerken in de dagelijks praktijk en het uitvoeren van de voorkomende werkzaamheden op de stageplek. Hier gaat het dus om het opdoen van werkervaring en het beroep uitoefenen waar ze voor worden opgeleid. Deze stage wordt meeloopstage, meewerkstage of leerarbeidsplaats (LAP) genoemd. De duur van deze periode varieert van één semester tot een heel jaar. In dit rapport gebruiken we voor de derdejaars stage verder de term 'meewerkstage'. Bij de meeste opleidingen sluiten studenten hun studie af met een onderzoeksopdracht in de praktijk: de afstudeerstage. ${ }^{9}$

\section{Eisen aan stage}

De opleidingen stellen inhoudelijke en formele kwaliteitseisen aan de stages en de bedrijven waar de stages plaatsvinden. Bijvoorbeeld: het stagebedrijf heeft geen relatie met een familielid van de student, er is een minimum aantal mensen werkzaam en er worden voldoende werkzaamheden geboden die passen binnen de doelen van de opleiding en het beroep waarvoor wordt opgeleid, zowel qua inhoud als niveau.

Daarnaast zijn er eisen die gelden voor de begeleiding door het stagebedrijf. De praktijkbegeleider moet bijvoorbeeld minimaal een hbo-diploma en een aantal jaar werkervaring hebben, de inhoud van de opdracht moet duidelijk zijn en door de praktijkbegeleider of opdrachtgever gefaciliteerd worden. Tot slot kan de afstand tot de opleiding een criterium zijn voor het goed- of afkeuren van de stageplek of stage-opdracht. Er gelden ook andere voorwaarden waar de student aan moet voldoen om op stage te mogen, zoals een minimum aantal studiepunten dat is behaald.

In eerste instantie melden studenten de stage zelf aan bij het stagebureau (ook wel externe betrekkingen genoemd) of de stagecoördinator, waarbij ze een formulier invullen op basis waarvan wordt bepaald of de stage en de student aan bovengenoemde eisen voldoen. Bij de meeste opleidingen geldt het streven dat de docent een bezoek brengt aan de stageplek gedurende de eerste twee weken van de stageperiode, onder andere om vast te stellen of daadwerkelijk aan deze eisen wordt voldaan.

8 Eén opleiding die deelnam aan het onderzoek, heeft al in het eerste jaar een korte stage. Deze is bedoeld ter oriëntatie. Het gaat om 4 of 8 weken en heet ook wel snuffelstage.

9 Bij één van de opleidingen uit het onderzoek is dit jaar nog sprake van afstuderen met de 'klassieke scriptie' door het doen van desktop research. Vanaf volgend jaar geldt op deze opleiding ook de zogenoemde afstudeer - of onderzoeksopdracht, of -stage. 


\section{Ondersteuning bij het vinden van stage}

Zoals genoemd stimuleren de opleidingen hun studenten om zelf op zoek te gaan naar een stageplek. Studenten krijgen nadrukkelijk de boodschap mee dat zij in eerste instantie zelf verantwoordelijk zijn voor het vinden van een passende stage.

Veel genoemde adviezen zijn: begin op tijd met zoeken ('neem een half jaar'), zoek naar een stage die 'je leuk vindt', gebruik je eigen netwerk want 'de meeste stages worden via-via gevonden', stuur veel (open) sollicitaties en altijd persoonlijk (na)bellen. Een docente beschreef het als 'niet wachten op antwoordadvies'.

Ter ondersteuning van het zoekproces bieden de opleidingen meestal ook een vacaturebank. Sommige locaties hebben een 'sobere' vacaturebank; bijvoorbeeld een online platform, met beperkte controle op de actualiteit en kwaliteit van de vacatures en stagebedrijven. Op andere locaties kunnen studenten gebruik maken van goed bijgehouden en uitgebreide lijsten met bedrijven (bijvoorbeeld via Linkedln of eigen systeem) en wordt erop gelet of bedrijven goed bekend staan bij de opleiding.

De meeste opleidingen uit dit onderzoek hebben een stagecoördinator en/of organiseren speciale spreekuren voor studenten die nog geen stage hebben. De stagecoördinatoren zijn de intermediairs tussen de opleiding en het werkveld. Op twee opleidingen loopt het contact met een vaste groep bedrijven via een adviescommissie, waarin ook een opleidingsmanager en een lector zitten.

Om studenten in contact te brengen met stagebedrijven organiseren bijna alle opleidingen (twee)jaarlijks een zogenaamde 'bedrijvendag' (opleidingen gebruiken ook wel de term speeddate, werkgeversdag en stagemarkt). Voor deze dagen worden werkgevers uitgenodigd om naar de opleiding te komen, zodat studenten en professionals uit het beroepenveld elkaar kunnen ontmoeten. Deze dagen zijn op sommige opleidingen facultatief, op andere opleidingen is aanwezigheid verplicht. Ook de vorm loopt uiteen per opleiding en varieert van een beurs, waarbij studenten met meerdere bedrijven een kort gesprek hebben, een aantal korte sollicitatiegesprekken met bedrijven tot een aantal andere netwerkactiviteiten, zoals workshops en presentaties.

\section{Toegang tot stage}

De geïnterviewde onderwijsprofessionals hebben het beeld dat vrijwel alle studenten relatief eenvoudig een meewerkstage vinden. Studievertraging door het niet kunnen vinden van meewerkstage komt zelden tot nooit voor. Over de hele linie geven professionals van de economische opleidingen minder vaak aan dat hun studenten problemen hebben bij het vinden van stages, dan de professionals die werken bij de rechtenopleidingen. 
Bij beide opleidingsrichtingen (economie en rechten) is sprake van een kleine groep studenten die kort voor de deadline nog geen meewerkstage heeft. Volgens de onderwijsprofessionals kunnen zij over het algemeen terecht bij de studieadviseur, een stagespreekuur of de stagecoördinator voor extra ondersteuning.

\section{Studievertraging door stage}

Professionals geven aan dat het bemachtigen van een afstudeerstage lastiger is dan de meewerkstage en dat het voorkomt dat studenten vertraging oplopen doordat zij niet tijdig een afstudeerstage vinden. ${ }^{10}$ Welk percentage van de vierdejaars studenten studievertraging oploopt door het niet vinden van een stage, kan op basis van dit onderzoek niet worden vastgesteld. Wel kunnen we vaststellen dat de opleidingen een beperkt aantal afstudeermogelijkheden in beeld hebben. Studenten zijn in de laatste fase van hun studie sterk op zichzelf aangewezen, terwijl het aantal mogelijkheden op de arbeidsmarkt voor een afstudeerstage (vijf maanden) kleiner is dan voor een meewerkstage. Ook tijdens de bedrijvendagen en speed-date's bieden de werkgevers vooral meewerkstages aan en nauwelijks afstudeerstages. Omdat het vinden van een afstudeerstage in de praktijk niet eenvoudig is gebleken, stellen opleidingen de eisen aan afstudeerstages nog wel eens naar beneden bij.

\section{Controle op de kwaliteit stages}

Onderwijsprofessionals geven aan beperkt tijd te hebben voor het bezoeken van stagebedrijven. Desalniettemin bestaat de indruk dat de kwaliteit van de begeleiding van studenten door de aanbieders van stages enorm uiteenloopt. Het komt voor dat stagebedrijven niet blijken te voldoen aan de eisen of dat zij studenten niet correct behandelen. Met dit type signalen gaan individuele onderwijsprofessionals verschillend om. Sommige medewerkers vertellen dat ze een 'zwarte lijst' hebben voor bedrijven die'echt niet voldoen'. Voor hen zijn gebrekkige begeleiding, discriminatie, pesten en seksuele intimidatie redenen om een bedrijf op die lijst te zetten. Weer andere onderwijsprofessionals benadrukken dat het belangrijk is om een bedrijf niet vals te beschuldigen. Zij waarschuwen er voor om een bedrijf niet 'te snel' op een zwarte lijst te zetten, willen voorzichtig zijn met de contacten van de opleiding en/of noemen het ingewikkeld om het gesprek met bedrijven aan te gaan. Geen van de geïnterviewden geeft aan bij dit soort situaties te handelen op basis van een protocol of van breder gedeelde afspraken binnen de opleiding.

\subsection{Werkgevers}

Voor dit onderzoek zijn interviews afgenomen met HR-professionals, managers of directeuren van bedrijven en organisaties in zowel de private als de publieke sector.

10 Op vier van de vijf locaties die deelnamen aan het onderzoek, doen studenten een afstudeeropdracht in de praktijk via een stage. Op één locatie was er tot dit jaar een theoretische afstudeeropdracht. 
Hieronder schetsen we de werkwijzen bij werving en selectie die we in deze interviews tegen zijn gekomen.

\section{Werving en selectie van stagiaires en starters}

In de meeste gevallen zetten de geïnterviewde werkgevers voor de werving en selectie voor zowel stages als banen een sollicitatieprocedure op. Informele werving via het persoonlijke netwerk van werkgevers vindt slechts incidenteel plaats. De organisaties verschillen in de hoeveelheid sollicitanten die voor een gespreksronde wordt uitgenodigd en het gebruik van aanvullende selectie-instrumenten zoals een assessment of videosollicitaties.

Het perspectief van werkgevers op het bieden van stages verschilt sterk. Bij de private bedrijven is het werk van stagiaires sterk verweven met de werkprocessen van de organisatie en dienen de stages bij te dragen aan de productiviteit van het bedrijf. Andere organisaties beschouwen het bieden van een stageplaats vooral als middel om maatschappelijke betrokkenheid te tonen, waarbij het bieden van kansen voor jonge mensen centraal staat. Het gaat hierbij zowel om publieke organisaties (gemeenten) als om kleinere private organisaties.

De geïnterviewde werkgevers kunnen bijna allemaal voorbeelden noemen van stagiaires die bij hun bedrijf of organisatie uiteindelijk in dienst zijn getreden. Soms was dit direct aansluitend op een stage het geval, na het afstuderen, en soms is een voormalige stagiair op een later moment naar het bedrijf teruggekeerd. Omdat stagiaires al bekend zijn met de organisatie en vice versa, kunnen zij in het geval van een vacature gemakkelijk instromen. Dit is volgens de werkgevers vooral een bijkomend effect van stages, het is dus geen standaard wervingsmodel zoals dat bijvoorbeeld van toepassing is bij traineeships met baangarantie.

In de context van reguliere banen zien we een verschil tussen grotere private ondernemingen en publieke organisaties. De grotere private werkgevers zetten trainee- of startersprogramma's op om talentvolle jonge medewerkers aan zich te binden. Het uitgangspunt bij deze programma's is het identificeren van de uitblinkers, de 'high potentials', en de insteek is dan ook competitief. Ook in publieke instellingen bestaan dit soort startersprogramma's, maar worden daarnaast programma's opgezet specifiek voor jongeren die een steuntje in de rug kunnen gebruiken. De ruimte die studenten krijgen om fouten te maken tijdens een selectieprocedure is groter bij publieke organisaties dan in de private sector.

\section{Wat vinden werkgevers en/of selecteurs belangrijk?}

Er bestaat grote consensus over de factoren die van belang zijn bij de selectie van zowel stagiaires als beginnende medewerkers. In de context van een stage zijn verschillende aspecten genoemd door de werkgevers. Allereerst motivatie en enthousiasme, blijkend 
uit zowel een schriftelijke sollicitatie als uit persoonlijk contact. Bij het aannemen van een stagiaire vormt een helder plan voor de stageperiode een belangrijke voorwaarde. Het helpt werkgevers als studenten een duidelijk idee hebben over de invulling van hun stageperiode, uiteraard afgestemd op het bedrijf in kwestie. Volgens de geïnterviewde werkgevers komen studenten vaak 'blanco' binnen, waardoor het uitwerken van een stageplan (te) veel aandacht vraagt.

Bij sollicitaties voor reguliere banen wordt er ook gekeken naar begrip van de functie en de organisatie. Selecteurs hechten belang aan gerichte sollicitaties waaruit blijkt dat de kandidaat zich kan inleven in de situatie van het bedrijf. Kennis van de betreffende sector en soortgelijke functies kunnen daarbij helpen. En tenslotte kijken selecteurs naar duidelijkheid over het eigen profiel. Werkgevers vinden het belangrijk dat sollicitanten, juist bij gebrek aan werkervaring, kunnen aangeven welke competenties zij hebben en hoe die aansluiten bij de functie.

Selecteurs zijn geneigd om negatief te oordelen over sollicitatiebrieven die niet expliciet zijn toegeschreven op de functie en die ogenschijnlijk voor veel verschillende sollicitaties worden gebruikt. Ook het schetsen van een indrukwekkend persoonlijk profiel zonder concrete onderbouwing van vaardigheden of ervaringen valt niet in de smaak. Taalfouten leiden bij sommige werkgevers direct tot afwijzing.

\section{Samenwerking met hbo-opleidingen}

De meeste geïnterviewde werkgevers hebben regelmatig, maar beperkt contact met hogescholen in hun regio. Er zijn de volgende voorbeelden van samenwerking genoemd: organisaties werken bijvoorbeeld mee aan een bedrijvendag op de hogeschool, zij weten dat zij op een lijst met stagebedrijven van de hogeschool staan, of zij worden soms gebeld door een stagebegeleider die een stagekandidaat onder de aandacht wil brengen. Als het gaat om het invullen van vacatures voor reguliere banen kijken werkgevers niet direct naar een opleiding als wervingskanaal. Een brede werving heeft dan hun voorkeur, ook bij trainee- of startersprogramma's. Verschillende respondenten willen wel een nauwere samenwerking, ook in het kader van de strategische personeelsplanning van hun organisatie. 


\section{Oorzaken van (on)gelijke arbeidsmarktkansen}

In dit hoofdstuk komen de geïnterviewde hbo'ers (studenten en afgestudeerden), onderwijsprofessionals en werkgevers aan het woord over ongelijke kansen op de arbeidsmarkt van hbo'ers met en zonder migratieachtergrond. ledere geïnterviewde is allereerst gevraagd of deze het vraagstuk van ongelijke toegang herkent en/of er ervaring mee heeft. Vervolgens is met de geïnterviewden gesproken over wat zij zien als de mogelijke oorzaken van het vraagstuk van ongelijke arbeidsmarktkansen. Dit hoofdstuk start met de hbo'ers in paragraaf 5.2, vanaf paragraaf 5.3 komen de onderwijsprofessionals aan het woord en de werkgevers sluiten af in paragraaf 5.4.

\subsection{De hbo'ers aan het woord}

Veel studenten komen via de stage voor de eerste keer in aanraking met het beroepenveld van de opleiding. De meeste hbo'ers van opleidingsrichtingen die deelnemen aan dit onderzoek ${ }^{11}$ (verder: hbo'ers) vinden het niet eenvoudig om uitgenodigd te worden voor een sollicitatiegesprek voor een stage. Veel hbo'ers - met en zonder migratieachtergrond - hebben de ervaring dat er niet of niet positief wordt gereageerd op sollicitatiebrieven.

De meerderheid van de geïnterviewde studenten en afgestudeerden - met en zonder migratieachtergrond - denkt dat er (wel eens) sprake is van ongelijke kansen op stages en werk. Zij signaleren dat kandidaten met een migratieachtergrond meer sollicitatiebrieven versturen, voordat zij een uitnodiging voor een gesprek ontvangen. De meeste geïnterviewden voegen daaraan toe dat vermoedens van discriminatie bij schriftelijk solliciteren moeilijk te bewijzen zijn, omdat bij afwijzingen nooit direct wordt verwezen naar de achtergrond van de persoon. Vermoedens van discriminatie worden gevoed door de ervaring dat de studenten zonder migratieachtergrond wel worden uitgenodigd voor een gesprek, terwijl hun medestudenten met een migratieachtergrond van de werkgever te horen krijgt dat de vacature reeds is vervuld. In paragraaf 5.2.3 gaan we verder in op de ervaring van hbo'ers met ongelijke kansen en discriminatie.

11 Aan dit onderzoek werkten studenten en afgestudeerden van hbo-rechten en economie mee. Studenten en afgestudeerden rechten hebben over de hele linie meer problemen benoemd om aan stage en werk te komen, dan hbo'ers economie. 


\subsubsection{Financiële situatie en werkervaring}

Voor studenten die geen financiële ondersteuning krijgen van hun ouders, vormen bijbanen, betaalde stages en/of lenen een voorwaarde om te kunnen studeren. De bijbaan vormt niet alleen een belangrijke voorwaarde om te kunnen studeren voor een grote groep hbo'ers, maar is ook van invloed op hun arbeidsmarktkansen. Veel geïnterviewde hbo'ers met een migratieachtergrond hebben een bijbaan buiten het beroepenveld waartoe zij worden opgeleid. Geïnterviewde afgestudeerden merken op dat een bijbaan buiten de sector uiteindelijk niet heeft bijgedragen aan hun netwerk en arbeidsmarktpositie (zie ook Box 5.1).12

Ik heb twee bijbanen, Kruidvat en bijles geven, maar dat is toch is iets anders dan een juridische baan. Sommige mensen eindigen op het bedrijf waar ze stagelopen, dat zou ik liever willen, maar is niet gelukt... De opleiding volg ik met gemak. Ik wil niet mijn lessen missen voor mijn werk, maar dat doen veel studenten die werken wel. Studenten met de Marokkaanse en Turkse cultuur betalen hun studie meestal zelf, net als bij veel Surinaamse mensen. Vanuit het geloof is lenen ook niet toegestaan... Ik betaal mijn studie ook zelf en ik wil ook niet lenen. (studente Recht, Marokkaanse achtergrond)

En dan is er nog een groep studenten met (financiële) zorgtaken die door omstandigheden moeten zorgen voor (alleenstaande) ouders of andere gezinsleden. Dit vraagstuk treft studenten van alle achtergronden en leidde bij studenten uit de onderzoeksgroep zonder uitzondering tot studievertraging. Hoewel dit probleem bij alle groepen studenten voorkomt, geven studenten met een migratieachtergrond vaker aan zich verantwoordelijk te voelen voor de thuissituatie.

Ja heel herkenbaar, alle telefoontjes, brieven van de gemeente, zorgverzekering oversluiten enzovoort. En altijd met dat idee in je hoofd: wat als dit fout gaat? Je hoofd zit zo vol met alles wat nodig is om te overleven. Die dingen staan op nummer 1 en de studie komt daarbovenop (student rechten, Poolse achtergrond)

Vaak hoor ik van autochtonen van: je hoeft toch geen zorg te dragen voor je ouders. Maar ik voel wel dat dit moet. Als er thuis wat speelt met een ouder, dat heeft dit voor mij prioriteit. Dit heeft mij ook vertraging bezorgd. Mijn moeder was op staande voet ontslagen, daardoor kregen we geen uitkering. Naast school werkte ik fulltime omdat ik een tijdje kostwinner was. Er is op de opleiding weinig begrip, omdat er niet gekeken wordt naar je privéomstandigheden. Studenten gaan pas naar een decaan met problemen als het echt moet. (studente rechten, Turkse achtergrond)

12 Het SCP toonde al eerder aan dat wanneer een sollicitant niet kan aantonen in bezit te zijn van 'herkenbare' werkervaring dit leidt tot een ongunstige positie op de arbeidsmarkt (SCP, 2010, p. 77). 


\section{Box 5.1 Verschil in herkenbare werkervaring}

Afgestudeerden merken op dat de toegang tot de arbeidsmarkt mede wordt bepaald door de werkervaring die zij hebben opgedaan voor en tijdens hun studie. Degenen met een bijbaan onder hbo-niveau of in een andere sector dan waarvoor zij worden opgeleid, hadden daar na hun afstuderen last van. Aan potentiële werkgevers en recruiters kunnen zij minder goed aantonen dat zij over passende competenties beschikken.

I ben niet echt tevreden met het werk dat ik tot nu toe heb gedaan. Ik ben voornamelijk werkzaam geweest in callcenters en ik werd op een bepaald moment een soort cassettebandje. Ik wilde meer uitdaging en toch meer op een persoonlijk niveau met mensen bezig zijn. (..) Maar het is me opgevallen dat wanneer men naar een CV kijkt dat bepaalde groepen door hun werkervaring gelijk in een bepaald hokje worden gezet. Omdat ik na het afronden van mijn studie voornamelijk in de klantenservice in de financiële dienstverlening heb gewerkt, word ik gelijk afgewezen of ontvang ik alsnog alleen maar callcenter vacatures (afgestudeerde economie, Antilliaanse achtergrond)

Een rechtenstudente koos voor een administratieve bijbaan bij een advocatenkantoor. Ze kwam daardoor aan haar stage en kon vervolgens doorstromen binnen het bedrijf.

Ik ben via een recruiter binnengekomen bij een advocatenkantoor voor een bijbaan, ik had op internet mijn cv geplaatst. Ze zochten iemand om het systeem te digitaliseren. Dat deed ik als bijbaan, en daarna kon ik er stagelopen. Ik zat in de OC en in de domeinraad, dus dat heeft misschien geholpen en dat ik houd van reizen stond op mijn cv. Daardoor straalde mijn cv misschien uit dat ik een bredere blik had (afgestudeerde rechten, Chinese achtergrond)

Een afgestudeerde, die sinds enkele jaren werkzaam is bij een HR-afdeling van een grote gemeente, signaleert dat studenten en afgestudeerden vaak onvoldoende het verschil maken tussen een startersbaan en een bijbaan. Hij constateert dat op de cv's van sollicitanten met een migratieachtergrond vaak bijbanen staan vermeld die niets te maken hebben met het niveau of de studie van de sollicitant.

Het gaat vaak mis als mensen onder hun niveau werken. Studenten zien het verschil niet tussen startersfunctie en onder je niveau werken. Onder aan de ladder beginnen betekent niet onder je niveau werken. Zit je in een kleine organisatie en blijf je dan drie jaar zitten, dan is je marktwaarde gedaald... Heel veel jongeren met een migratieachtergrond hebben het gevoel: ik sta sowieso achter en die werken onder hun niveau. Kunst is het als opleiding om de onderliggende redenen aan te pakken, de onzekerheid, als je het gevoel hebt 'ik sta sowieso achter', dan ga je solliciteren op een baantje bij de pizzakoerier.' (afgestudeerde economie, Marokkaanse 
achtergrond)

De hbo'ers met migratieachtergrond die in deze situatie terechtkwamen, gaven tijdens de interviews aan 'al blij te zijn iets' gevonden te hebben, maar merkten op dat de stagebedrijven (in dit geval kleine deurwaarderbedrijven en bewindvoeringskantoren) weinig tot geen begeleiding boden. Verschillende studenten met een Nederlandse achtergrond kwamen ook terecht bij 'slechte' stages en bijbanen buiten het beroepenveld. Zij stapten op of vroegen om ander werk, in tegenstelling tot de geïnterviewde studenten met migratieachtergrond die de situatie accepteerden.

Studenten voelen vaak dat ze in een zwakke positie staan ten opzichte van een bedrijf. Maar hoe sterker jijzelf in je schoenen staat, hoe minder last je daarvan hebt. Als je denkt dat je een stap achter staat, dan ben je eerder bereid om een stage te accepteren die niet goed is. Ik ben na een week weggegaan bij mijn eerste stage. Ik zei: 'Ik leer hier niets'. De eigenaar zei: 'Je leert hier bellen'. (student economie, Nederlandse achtergrond)

\subsubsection{De manier van netwerken}

Volgens de geïnterviewde hbo'ers heeft 'het netwerk' van een werkzoekende grote invloed op diens arbeidsmarktkansen. Een breed gedeelde overtuiging is dat studenten en afgestudeerden met werkende ouders en studenten met een Nederlandse achtergrond vanwege hun 'relevante' netwerk een voorsprong hebben op de arbeidsmarkt ten opzichte van degenen die opgroeien met ouders zonder werk en/of ouders met een migratieachtergrond. Een netwerk bestaat, volgens de beschrijving van studenten en afgestudeerden, in de eerste plaats uit familie, vrienden, medestudenten en soms buren of kennissen van ouders.

Mijn vader werkt niet en mijn moeder is 20 jaar geleden overleden. Dus heb ik ook geen relevant netwerk. Mensen met twee werkende ouders hebben een veel groter netwerk. Bij dit netwerk speelt de migratieachtergrond wel een rol, want als eerste generatie migrant val je net buiten de boot. (studente rechten, Marokkaanse achtergrond, 20)

Zoeken naar een stage gaat moeizaam. Via google kijk ik op: hbo-rechten, stage. Ik snap niet waar al die stagiaires hun plek vinden. Ik zie bijna niks open staan. Ik hoor dan vaak: het gaat via via. Ik heb niet zo'n netwerk. Ik reageer dus liever op vacatures. Ik durf gelukkig wel makkelijk te vragen. (studente rechten, Turkse achtergrond)

Toen ben ik op gesprek geweest bij de gemeente. Dit had niet mijn voorkeur van het rechtsgebied, maar ik was wanhopig. De school gaat er namelijk van uit dat iedereen een heel goed netwerk heeft met nuttige mensen en niet iedereen heeft dit. Een netwerk is wel heel belangrijk voor een afstudeerstage, daar zouden ze meer bij kunnen helpen. Daarnaast kan 
de opleiding meer doen om de positieve mindset bij studenten met een migratieachtergrond te stimuleren, hen te motiveren. (studente rechten, Marokkaanse achtergrond)

Voor mijn afstudeerstage heb ik 26 brieven gestuurd, ik heb er nog een heel bestand van, de helft ongeveer open sollicitaties, de andere helft vacatures via de opleiding, van sommigen heb ik niks gehoord, verder heb ik veel afwijzingen ontvangen, 12 afwijzingen.' (afgestudeerde economie, Surinaamse achtergrond).

De geïnterviewde hbo'ers met een autochtone achtergrond herkennen zich, desgevraagd, minder in het beeld dat zij betere netwerken hebben dan hbo'ers met een migratieachtergrond. Een aantal van de geïnterviewden zonder migratieachtergrond vertelt uit een gezin te komen met een lage sociaaleconomische achtergrond en geeft aan meer ondersteuning nodig te hebben van de opleiding.

Netwerk? Geen idee, kijk mijn vader is bouwvakker en mijn moeder werkt in een slagerij. Dus, aan wie moet je vragen of ze misschien een stageplek weten of werk hebben? De boodschap op de opleiding was: 'Als je het wil, dan kan je het'. In principe is dat niet fout maar ik denk wel dat het belangrijk is om te weten hoe het echt werkt. Als jij 40 brieven schrijft word je 40 keer afgewezen. Je hebt werkervaring nodig, contacten en een echt specifieke brief. Of we begeleiding kregen? Nee totaal niet, zelf brieven schrijven daar komt het op neer.... (afgestudeerde rechten, Nederlandse achtergrond)

Wat er echt nodig is voor een gelijke start weet ik niet. Maar in ons jaar is meer dan de helft niet op tijd afgestudeerd. Van de 30 studenten vonden er maar twaalf een afstudeerstage. Het was een gemengde groep, studenten met en zonder migratieachtergrond. Ik had het geluk dat mijn moeder, met veel moeite, bij haar werk in een verzorgingstehuis een stage voor mij kon vinden. Van de 20 sollicitaties had ik maar van 1 bedrijf een reactie terug gehad. Zo ging dat echt met iedereen. Maar twee studenten zijn op tijd afgestudeerd, ik en een ander klasgenootje. (afgestudeerde economie, Nederlandse achtergrond)

Naast het sociale netwerk zien de hbo'ers het gebruik van een online netwerk als bepalend voor het vinden van een stage en werk. Waarbij degenen die hun online netwerk open en actief benaderen in het voordeel zijn. Mede op aanraden van de opleidingen wordt Linkedln vaak gebruikt voor het zoeken van een stage en werk.

Verschillende geïnterviewden signaleren dat studenten met een migratieachtergrond, vooral vrouwelijke studenten met een islamitische achtergrond, zich bescheidener presenteren op LinkedIn. Een geïnterviewde studente met een Marokkaanse achtergrond vertelde vanwege haar cultuur moeite te hebben zich 'zo openlijk' op social media te presenteren. Daardoor zouden zij en haar vriendinnen met een islamitische achtergrond minder zichtbaar zijn voor recruiters en werkgevers dan studenten met een Nederlandse achtergrond. 
Verschillende afgestudeerden met een migratieachtergrond vertellen dat zij in de praktijk ontdekt hebben wat de voordelen zijn van een directere manier van netwerken. Zij benaderden bijvoorbeeld managers met vragen over hun bedrijfsvoering en wekten daardoor de interesse van recruiters van de organisatie waar zij wilden werken.

Ik wilde bij een gemeente werken, maar ik kwam nergens binnen omdat ik op dezelfde manier solliciteerde als de rest. Ik ben toen slim gaan netwerken, met meer durf ook. Ik heb bijvoorbeeld via LinkedIn een persoonlijk bericht gestuurd naar een directielid. Toen ik haar had toegevoegd heb ik gevraagd wat zijn de opdrachten die jullie hebben? Wat zijn de uitdagingen? Daar wilde ze wel over in gesprek met mij. Mensen vinden het leuk om over zichzelf te spreken, is ook een stukje psychologie. (afgestudeerde economie, Nederlandse achtergrond)

\subsubsection{Ongelijke kansen bij (stage) bedrijven}

De overgrote meerderheid van de geïnterviewde hbo'ers heeft veel sollicitatiebrieven geschreven, voordat zij daadwerkelijk een uitnodiging ontvingen voor een sollicitatiegesprek voor een stageplek. De ervaring dat brieven vaak niet worden beantwoord werkt bij een deel van de studenten negatief op het vertrouwen in de kansen op een succesvolle sollicitatie. ${ }^{13}$ Studenten met alle achtergronden hebben hier last van, maar studenten met een migratieachtergrond vaker. Een deel van de geïnterviewden met een migratieachtergrond vertelt dat de afwijzingen invloed hadden op het vertrouwen in de eigen competenties tijdens de procedure. Zij geven aan hierdoor ook te twijfelen over kansen(gelijkheid).

Ik liep stage bij een groot rechtsbijstandskantoor. Ik heb bij 41 bedrijven gesolliciteerd. Dit kantoor was het enige dat mij wilde, dus 40 niet. Van 37 bedrijven kreeg ik zelfs geen enkele reactie. Ik heb het echt op de ouderwetse manier gedaan, zoals ze je dat leren hier op school, met nabellen en alles. Dan komt er geen reactie en dan is de vraag waar dat aan ligt. Ik weet dat ik echt wel een goed CV heb, ik ben voorzitter van de MR, ik ben politiek actief, ik werk naast mijn studie .... Deze organisatie had helemaal niet mijn voorkeur, maar ja, je moet toch doorgaan met solliciteren. Ik ging aan mezelf twijfelen: heb ik wel echt wat te bieden of niet? (student rechten, Poolse achtergrond)

Verschillende hbo'ers ervaren dat sollicitanten die lijken op de werknemers van het bedrijf een 'hogere gunfactor' hebben bij de werkgevers. Deze mechanismen herkennen de geïnterviewden vooral in de commerciële wereld.

Ik merkte tijdens mijn zoektocht naar een stageplek dat de studenten die het steeds niet lukte om een stageplek te bemachtigen altijd de buitenlandse studenten waren. In sommige gevallen waren de motivatiebrief en het CV bijna hetzelfde maar toch lukte het de ene wel

13 Afgestudeerden met een migratieachtergrond die deelnamen aan het eerste deel van dit onderzoek hadden een lagere 'self-efficacy' dan de afgestudeerden zonder migratieachtergrond. Self-efficacy is de term voor 'vertrouwen en geloof in persoonlijke capaciteiten om het leren te organiseren en die taken uit te voeren, waarmee leerdoelen bereikt worden' (Bandura, 1997). De uitkomsten lijken te duiden op een verband tussen lage self-efficacy en een moeizame toegang tot stages. Zie ook paragraaf 5.2.4. 
en de ander met een niet westerse achtergrond niet om een stageplek te bemachtigen... Verder denk ik ook dat westerse mensen onbewust een gunfactor hebben, dat ze net die klik hebben bij een sollicitatie, en dat het in hun voordeel werkt. Natuurlijk zullen er mensen zijn die echt racistisch zijn, maar dat zullen ze nooit zeggen in je gezicht ik heb ook nooit concrete ervaring gehad. (student economie, Marokkaanse achtergrond)

Ik en mijn klasgenoten solliciteerden via dezelfde manier, via Linkedln, eigen netwerk, en vacturesites. Bijna allemaal hebben ze via de vacaturebank wat gevonden. Maar ik ben wel aangenomen bij het eerste gesprek en ik weet van klasgenoten dat ze meerdere gesprekken bij verschillende bedrijven hebben gehad. Ik denk dat het ook ligt aan de presentatie van een persoon, en of je je snel kunt aanpassen aan de omgeving en aan de mensen. (afgestudeerde rechten, Nederlandse achtergrond)

De geïnterviewde hbo'ers menen dat grotere (internationale) bedrijven en de overheid aan kandidaten met en zonder migratieachtergrond vaker gelijke kansen bieden dan de kleinere commerciële bedrijven en kantoren.

Ik solliciteerde echt op alles, ik heb achteraf mijn brieven gelezen en die waren heel breed, dat was achteraf niet goed genoeg. Ik weet inmiddels dat je moet opvallen met je brief. Mijn stage heb ik via mijn vader, die werkt voor een verzekeringskantoor en die heeft mijn stage geregeld. Ik heb geluk dat ik zo'n vader heb... Ik heb ook veel bijbaantjes gehad. Bij de grote bedrijven zoals $A B N$ en XS4All heb ik nooit problemen gehad, je moet zelfverzekerd zijn, dan straal je dat uit. Tot ik bij een stijf advocatenkantoor solliciteerde, toen merkte dat ik niet doordrong, hoe hartelijk ik ook was (afgestudeerde rechten, Marokkaanse achtergrond)

\section{Discriminatie}

Over de mate waarin discriminatie van invloed is op arbeidsmarktkansen doen weinig studenten en afgestudeerden harde uitspraken. Opvallend veel studenten met en zonder migratieachtergrond maken opmerkingen waaruit twijfel spreekt, zoals 'je kan discriminatie niet bewijzen', 'het zal er wel zijn, want je hoort erover in de media', 'ik zie geen diversiteit bij het bedrijf, dus ik neem aan dat het speelt' en 'ik heb zelf heb geen discriminatie meegemaakt, maar vrienden wel'.

Ik heb zelf geen discriminatie ervaren, maar in mijn stagebedrijf zit iets niet goed. Want in het contract las ik dat je geen hoofddoek op mag. Dat liet mij al denken, waarom mag dat niet? Dan kom je erachter dat mensen met hoofddoek en religieuze overtuigingen niet welkom zijn. Dat trek ik mij persoonlijk wel aan. Gevoel alsof je wel een geloof mag hebben, maar je er niet tussen hoort' (student economie, Turkse achtergrond)

Ook wordt vaak genoemd dat discriminatie 'een van de redenen' is van ongelijke toegang en dat ook je financiële (thuis)situatie en netwerk een rol speelt. Een minderheid van de studenten en afgestudeerden met een migratieachtergrond (3 van 31) wijst discriminatie aan als de belangrijkste of enige oorzaak van ongelijke kansen op de arbeidsmarkt. Twee 
van hen hebben een vluchtelingenachtergrond. Ongelijke kansen ervaren deze respondenten in meerdere contexten en van jongs af aan. 'Het systeem in Nederland is niet ingericht om ons mee te laten doen', vatte een van hen het samen.

Wanneer de hbo'ers met een niet-westerse achtergrond wordt gevraagd naar de eigen ervaring met discriminatie, geeft de meerderheid aan wel vermoedens, maar weinig bewijzen te hebben. Vrijwel allemaal zien zij het grote aantal afwijzingen en niet beantwoorde sollicitatiebrieven als teken dat er 'mogelijk' sprake is van ongelijke kansen of discriminatie op basis van achternaam.

Ook vertellen verschillende hbo'ers met een migratieachtergrond over vragen die hen tijdens een sollicitatiegesprek werden gesteld, waarmee zij impliciet werden uitgesloten. Zij noemden voorbeelden als:'hebben je ouders gestudeerd?', 'heb je in het corps gezeten?', 'we maken hier harde grappen, als het over jouw cultuur gaat moet je daar wel tegen kunnen'.

Een oud klasgenoot is nu klant van een bekend advocatenkantoor. Hij regelde voor mij een gesprek over een stage. De advocaat vroeg naar mijn familie en hun opleiding. Die advocaat zei: 'Jouw achtergrond past niet bij ons bedrijf, je hebt niemand in de familie die 'meester' is. Dat is schade voor de reputatie van ons bedrijf. Dit is een vader op zoon bedrijf, wij werken voor topbedrijven.' (studente rechten, Marokkaanse achtergrond)

Zes van de dertig geïnterviewde studenten met een migratieachtergrond geven expliciet aan gediscrimineerd te zijn door stagebedrijven, tijdens een sollicitatiegesprek. Vier van deze zes studenten droegen een hoofddoek. ${ }^{14}$

Ik voel mij weleens gediscrimineerd bij het zoeken van een stage, omdat ik het gevoel krijg dat bepaalde bedrijven eerst naar het uiterlijk van een persoon kijken, bij het dragen van een hoofddoek, in plaats van naar de kwaliteiten die een persoon heeft. Dit is iets wat ik zo jammer vind en tegelijkertijd geeft dit mij een heel onzeker gevoel. Ik heb al meerdere keren gesolliciteerd voor een meewerkstage, aangezien ik bijna moet afstuderen. Dit is moeilijker dan ik had gedacht. Tijdens mijn mbo-studie ging dit veel makkelijker, maar toen droeg ik nog geen hoofddoek. De opleiding zou bijvoorbeeld contact kunnen leggen met dit soort bedrijven. (studente economie, Marokkaanse achtergrond)

De helft van de geïnterviewde studenten met discriminatie-ervaringen heeft dit niet gemeld op de opleiding. Zij willen hun stage er niet mee in gevaar brengen.

14 Het is Nederland niet toegestaan om een sollicitant af te wijzen vanwege het dragen van een hoofddoek of om te vragen de hoofddoek niet te dragen. Dit mag alleen wanneer in de statuten van het bedrijf staat opgenomen dat werknemers geen enkele religieuze of politieke uiting mogen dragen of wanneer de veiligheid in geding is. Studenten en onderwijsprofessionals waren hier niet van op de hoogte. 
De opleiding zegt: 'Escaleer het naar ons, zodat wij met het bedrijf in gesprek kunnen.' Dat ga je niet doen, want dan snij je jezelf in de vingers. Dan liever doorbijten. (student economie, Marokkaanse achtergrond)

Anderen geven aan lage verwachtingen te hebben van de reactie van de opleidingen, omdat de opleidingen uitdragen dat ze iedereen gelijk behandelen en geen invloed hebben op de bedrijven. Een van de studenten heeft van haar docent het advies gekregen haar hoofddoek af te doen, nadat de studente had aangegeven dat ze vanwege haar hoofddoek geen toegang kreeg tot stages. De studente die het advies van de docente opvolgde, werd kort daarna aangenomen. Ze ervaart het als onprettig, maar noodzakelijk om haar studie af te kunnen maken.

Ik heb het tegen de stagecoördinator gezegd. Ik kom maar niet aan de bak. Haar collega heeft mij toen geadviseerd om mijn hoofddoek af te doen. Ik merk dat het verschil uitmaakt, dat je naam en achtergrond meespelen. Met hoofddoek krijg ik geen enkele reactie op sollicitaties. In mijn geval heb ik mij aangepast, in de zin van cv zonder hoofddoek, en daarna kwamen er toch reacties binnen. ...lk heb er geen problemen mee. Ik ben vrij opgevoed en voel me niet minder moslim doordat ik mijn hoofddoek afdoe. Ik wil gewoon werken. (studente rechten, Marokkaanse achtergrond)

Dat onderwijsprofessionals een student - en niet de werkgever - adviseren om zich aan te passen is vaker verteld door geïnterviewde hbo'ers. Unaniem geven zij aan dat de opleiding een actievere houding zou kunnen innemen richting de bedrijven, om daarmee gelijke kansen te creëren. Een studente legt uit dat door het 'gelijkheidsbeginsel'van de opleiding er niets verandert aan de ongelijke kansen op stages.

$J a$, de inzet van de opleiding is: iedereen is gelijk. Dus iedereen krijgt hetzelfde. Maar bewust en onbewust weten we dat we niet gelijk zijn. Mensen die geen migratieachtergrond hebben, zijn er alleen minder mee bezig. Als de docenten zich wel zouden uitspreken over ongelijke kansen op de opleiding en tegen bedrijven, dan wordt er meer geluisterd. Als we samen schreeuwen heeft het meer impact (afgestudeerde economie, Kaapverdische achtergrond)

Andere studenten geven aan niets te melden bij de opleiding, omdat ze niet verwachten dat de opleiding daadwerkelijk verschil kan maken richting de werkgevers. Zij zijn bovendien bang dat ze zij door het melden van discriminatie hun stageplaats kwijtraken.

\subsection{4 (Zelf)vertrouwen en coping}

Studenten en afgestudeerden signaleren dat introverte of onzekere studenten - met en zonder migratieachtergrond - meer moeite hebben om een stage te bemachtigen.

Ik ben sociaal en enthousiast, maar mijn klasgenoot is meer op zichzelf gekeerd. Zij is ook Nederlandse, en had heel erg veel moeite met een stage zoeken, omdat de gesprekken niet lekker liepen. Voor deze studenten wordt niets aangeboden. Zij missen persoonlijke begelei- 
ding vanuit de opleiding, nu zegt de opleiding alleen: 'Het is je eigen verantwoordelijkheid' (studente economie, Nederlandse achtergrond)

Van sollicitanten met een meer bescheiden of meer gesloten houding - wat volgens de respondenten naar verhouding vaker het geval is bij sollicitanten met een niet-westerse achtergrond - zouden werkgevers minder snel overtuigd zijn (Box 5.2). Een studente met een migratieachtergrond die werkt bij een groot advocatenkantoor ervaart dat 'jezelf kunnen verkopen' en cijfers de belangrijkste criteria zijn bij de selectie. Hoewel het thuisland van de ouders nog steeds een obstakel kan zijn.

Ik denk dat op de Zuidas wel de cijfers die je haalt belangrijker zijn en niet je etnische achtergrond. Ik werk daar nu zelf en zie zoveel diversiteit. Maar je moet jezelf wel goed kunnen verkopen, overtuigingskracht en motivatie hebben. Als je dat niet hebt, dan is het moeilijker. Ik heb zelf nooit problemen gehad met het vinden van werk. Maar in mijn omgeving heb ik wel gezien dat een Afghaanse studente met een mooi cv, en twee masters en mooie werkervaring, bij veel Zuidas kantoren is afgewezen. Ze zeiden omdat ze niet cum laude was afgestudeerd, maar ik vermoed dat het lag aan haar Afghaanse achtergrond (studente rechten, Portugees Koerdische achtergrond)

Jezelf kunnen verkopen en zelfvertrouwen uitstralen is dus belangrijk bij sollicitaties, maar volgens verschillende geïnterviewden is dat niet eenvoudig als je vaak is verteld of meemaakt dat je geen gelijke kansen krijgt. Meerdere hbo'ers met een migratieachtergrond vertellen dat zij als kind van hun ouders of van mensen in hun omgeving de boodschap kregen 'je staat als migrant met 1-o achter, je moet altijd harder werken'.

Tot nu toe ben ik wel vaak gelijkwaardig behandeld, maar ik heb het vaak anders gezien bij anderen. Het geeft mij meer een drive om niet alleen te vertrouwen op de eerlijkheid van mensen. Ik heb meegekregen vanuit mijn jeugd: je staat eigenlijk 1-o achter en je moet altijd meer doen om te komen waar je wilt zijn. (student economie, Turkse achtergrond

Ook van enkele onderwijsprofessionals met een migratieachtergrond hoorden we dat zij studenten adviseren extra hun best te doen vanwege ongelijke arbeidsmarktkansen. Zij vertelden dat zij studenten op deze manier willen behoeden voor een teleurstelling wanneer zij de arbeidsmarkt opgaan en 'dan pas' ontdekken dat er sprake is van ongelijke kansen. Zie verder: paragraaf onderwijsprofessionals. 


\section{Box 5.2 Vertrouwen in kansen}

We tekenden verschillende ervaringen op van studenten met een migratieachtergrond die positief zijn gestart aan hun hbo-opleiding, maar die gaandeweg de studie steeds minder vertrouwen kregen in hun eigen capaciteiten en kansen. Overeenkomst was dat zij zich tijdens het zoeken naar stages weinig ondersteund voelden door de opleiding en dat hun zoektocht naar stages moeizaam verliep. Uiteindelijk ging dat ten koste van hun vertrouwen in een succesvolle sollicitatie en hun presentatie tijdens de sollicitatieprocedure. Zo vertelden een aantal van hen.

Ik denk wel dat ik minder kans had, maar niet omdat ik niet-westers ben maar omdat ik weinig vertrouwen heb gekregen tijdens de opleiding. In het begin was ik optimistisch, maar ik werd zo vaak afgewezen, dat daardoor mijn vertrouwen wegging. Een laag zelfvertrouwen herken ik wel, ook bij andere studenten met een migratieachtergrond. Daardoor zijn sommige studenten bang zichzelf teveel te profileren. Ik zie dat bij mezelf voorbeeld: $i k$ schreef in een brief "al kan ik maar twee minuten het proces verbeteren". Dat was achteraf gezien te bescheiden, want wat is nou twee minuten (student economie, Marokkaanse achtergrond) Sommige opmerkingen van docenten werken demotiverend. Ik zag wel voornamelijk bij mensen met een migratieachtergrond een ongelijke behandeling door docenten. Zelf ben ik gemotiveerd van jongs af aan. Maar iemand die dat niet is, of thuis ook hoort dat hij een mislukkeling is, is gevoelig voor demotiverende opmerkingen van een begeleider, wat de prestaties wel kan beïnvloeden ... Vooral allochtone vaders willen dat hun kind per se advocaat wordt. Van kleins af aan worden ze heel hard aangepakt. Op school, is een positieve turn nodig om niet moedeloos te worden (studente rechten, Turkse achtergrond)

Het omgaan met (de mogelijkheid van) ongelijke kansen doet iedere student anders. Een aantal studenten vertelt dat zij een uitmuntende student willen zijn en extra veel doen voor de studie. Zij kiezen er bovendien voor om positief te blijven, want 'als het anderen lukt, waarom mij dan niet?'

Het eerste waar ik aan denk is een goed cv. Hier ben ik zelf bewust mee bezig. Zo ben ik bijvoorbeeld voorzitter van de opleidingscommissie. Ik moet uitblinken om een goede kans te hebben op een baan. Je hoort veel mensen zeggen: 'Mensen met migratieachtergrond hebben een streepje achter. Zo wil ik niet denken, maar het zit achterliggend ergens wel in mijn gedachte. Anders had ik mij misschien niet zo extra ingezet...lk heb zelf geen negatieve ervaringen, maar ik denk ook: als je negatief gaat denken, dan werkt het tegen je. Voor mijn afstudeerstage moest ik bijna 30 brieven sturen. Je kan dit zelf invullen van:'Oh, dit zou wel discriminatie kunnen zijn.' Ik denk daarentegen:'Ze zoeken waarschijnlijk geen stagiairs op 
dit moment.' Dus ik maak een keuze: het is een mind-set. (studente rechten, Marokkaanse achtergrond)

Ik krijg vanuit mijn omgeving wel heel vaak de vraag of ik het moeilijk heb met het vinden van werk of op het werk. Ook omdat ik een hoofddoek draag. Die vraag krijg ik van alle groepen, dus van familie en vrienden, maar ook van Nederlanders. Al op de havo kreeg ik daar vragen over. Mijn antwoord op die vraag is altijd geweest:' Waarom zouden ze daar moeilijk over doen? Ik denk niet dat het voor mij een probleem zal zijn. Ik denk dat ik wel beoordeeld zal worden op mijn kwaliteiten en ik koppel een afwijzing niet aan mijn achtergrond, ik neem een afwijzing niet persoonlijk' (afgestudeerde rechten Afghaanse achtergrond).

Anderen geven aan nadrukkelijk niet bezig te willen zijn met kansenongelijkheid en concurrentie. Zij zoeken naar een werkplek waar zij een minder harde selectie verwachten. De overheid en non-profit organisaties zijn in dit kader vaak genoemd. Door vooral de HBO-rechten studenten zijn gemeenten vaak genoemd als aantrekkelijke werkgevers, ook vanwege de informelere werksfeer.

Ik zou liever als juridisch medewerker of adviseur aan de slag gaan. Het liefst bij de gemeente. Dit heeft vooral te maken met de werksfeer en hoe er met je wordt omgegaan: een informele werksfeer en liever minder zakelijk. Ik heb er veel vertrouwen in om een baan te krijgen. Veel medestudenten hebben allemaal plekje gevonden, waarom ik dan niet? (student rechten, Marokkaanse achtergrond)

En dan zijn er enkele studenten die anticiperen op ongelijke kansen door werk te zoeken in de 'eigen' groep. (KIS, 2016c) Een recruiter met een Turkse achtergrond vertelde over zijn een bezoek aan een bedrijvendag van zijn eigen opleiding het volgende: "Turkse studenten kwamen op mij af met de vraag: 'Krijg ik gelijke kansen?' Ze zochten mij op vanwege de herkenning en omdat ze weten dat ze minder kansen maken bij andere bedrijven."

Je stelt je ambities bij als je geen voorbeelden ziet die op jou lijken. Je ziet alleen maar witte mensen op posities in het onderwijs. Je moet geloven dat je een andere toekomst kan hebben. Wij leven in communities, dat is ook wel cultureel bepaald... Ik zie geen harde discriminatie als verklaring voor de moeizame toegang tot de arbeidsmarkt. Ik zie ook puur gemak om veilig en dichtbij te blijven. (student economie, Marokkaanse achtergrond)

Ik constateer dat overal waar ik binnenkom het via via is geweest. Ik was lange tijd bezig met een stage zoeken en werd afgewezen of kreeg helemaal geen antwoord. Ik ben een jongen met een kleurtje, ik wil het niet gooien op discriminatie, maar het zou wel kunnen. Mijn cv is goed, mijn taal is goed, ik laat alles checken. Ik zie dat Marokkaanse en Turkse Nederlanders vaker gaan werken bij iemand van dezelfde achtergrond, dit speelde op het mbo nog sterker (afgestudeerde economie, Kaapverdische achtergrond) 


\subsubsection{Ondersteuning opleiding}

Studenten beschouwen de opleiding als mogelijke schakel ${ }^{15}$ tussen hun eigen wereld en de arbeidsmarkt. Er is veel waardering voor de opleidingen die eerste studiejaren starten met het geven van voorlichting over stages en die ter voorbereiding op de stageperiodes activiteiten organiseren gericht op het vergroten van het netwerk van studenten. De studenten en afgestudeerden die aangeven dat zij goed en persoonlijk contact hebben (gehad) met een docent of de coördinatoren (van stages, langstudeerders), beschrijven dat contact als 'redding' in tijden dat ze stress ervaarden vanwege het zoeken naar stages. Het ontbreken van persoonlijk contact, hulp of bemiddeling, lijkt zich te vertalen in verminderd vertrouwen in arbeidsmarktkansen.

We werden goed voorbereid. Het was heel lang van tevoren al bekend per wanneer je op stage moest en wat er verwacht werd. Ook waren er informatiedagen. Verder werden weer een aantal samenwerkingspartners van de hogeschool benoemd waar je ook terecht kon voor hulp met het vinden van een stageplek. (afgestudeerde economie, Antilliaanse achtergrond)

Ik vind dat er weinig ondersteuning was bij het zoeken naar een afstudeerstage. Zo van: 'Ga maar zoeken, veel plezier.' Op een gegeven moment ben ik wanhopig naar een docent gegaan; met deze docent had ik een goede klik en die heeft zijn netwerk gebruikt. Hij zei:'Wat zoek je?' Ik zei: 'Alles, als ik maar een stage krijg.' Nou binnen 5 minuten had hij al iets. (afgestudeerde rechten, Marokkaanse achtergrond)

Wat ik zelf erg miste was dat professionals uit het werkveld naar school komen om hun ervaringen te delen. I $k$ vind dat de opleiding zelf ook een netwerk met bedrijven en overheden moet onderhouden. Wat ik nog zou willen benadrukken is dat met het bieden van een lijst met stagebedrijven de studievertragingen voorkomen kunnen worden. Nu is de student erg op zichzelf en zijn netwerk aangewezen. (afgestudeerde rechten, Turkse achtergrond)

Van alle geïnterviewden zijn degenen met een vluchtelingenachtergrond wellicht het meest uitgesproken over hun behoefte aan individueel contact en ondersteuning vanuit de opleiding. Zij wijzen erop dat de nieuwkomers vaak een complexere thuissituatie hebben en dat zij er behoefte aan hebben dat hun verhaal beter wordt begrepen door docenten. Dat kan alleen door oprecht contact te maken, concludeert een van hen.

Voor een buitenlandse student is het leven heel anders, naast de studie. Ik ben ook zus, moeder voor mijn broer, ik onderhoud mijn ouders, ik ben de brug over de kloof tussen mijn familie en Nederland. Dus als de studie niet goed gaat, komt dat niet omdat je niet kan of niet wil, maar je hebt zoveel andere rollen. Wat ik nodig had gehad was iemand die naar mij had gekeken, achter dat studentennummer. Studenten komen naar school voor het gesprek. (afgestudeerde rechten, Congolese achtergrond).

15 Omdat de invloed van de opleidingen op (het versterken van) gelijke kansen onderwerp vormt van de volgende hoofdstukken, gaan we hier in dit hoofdstuk slechts beperkt op in. 
Ten slotte is door de hbo'ers vaak genoemd dat de beheersing van de Nederlandse taal een rol speelt bij de arbeidsmarktkansen. Het valt daarom des te meer op dat veel geïnterviewde hbo'ers aangeven te twijfelen over het eigen taalniveau. Deze twijfel is vaker geuit door studenten die van het mbo komen en door studenten met laagopgeleide ouders. Rechtenstudenten merken unaniem op dat docenten weliswaar regelmatig kritiek leveren op hun taalgebruik, maar dat de ondersteuning op het gebied van taal beperkt is. Het valt verschillende studenten met een migratieachtergrond op dat docenten hen strenger beoordelen op taal dan de studenten zonder migratieachtergrond (zie ook paragrafen over onderwijsprofessionals). Studenten en afgestudeerden van de economische opleidingen zijn over de gehele linie meer tevreden met het taalaanbod van hun opleiding dan studenten en afgestudeerden van de juridische hboopleidingen.

\subsection{De onderwijsprofessionals aan het woord}

\subsubsection{Onderwijsprofessionals over (on)gelijke kansen}

Wanneer met de onderwijsprofessionals wordt gesproken over de ongelijke arbeidsmarktpositie van hbo'ers met en zonder migratieachtergrond, levert dat een zeer diffuus beeld op. Een deel van de geïnterviewde medewerkers twijfelt of er bij stages sprake is van ongelijke behandeling of discriminatie door werkgevers. Deze medewerkers brengen ongelijke kansen, vergeleken met hun collega's, vaker in verband met het taalniveau (meer fouten) en de houding (onvoldoende initiatief) van de sollicitant met een niet-westerse achtergrond. Andere medewerkers zeggen wel te herkennen dat er sprake is ongelijke toegang tot stages en zien onder meer een relatie met bewuste of onbewuste discriminatie. Opvallend is dat de meeste onderwijsprofessionals aangeven dat de opleiding beperkt contact heeft met alumni. Men vermoedt dat de groepen die kwetsbaar zijn tijdens hun studie, dat ook daarna zijn, maar vrijwel geen van de medewerkers heeft daar 'bewijzen' voor.

Over de uitlopende beelden van de arbeidsmarktkansen en de rol van discriminatie wordt in de dagelijkse praktijk weinig gesproken binnen teams. Daar zijn meerdere redenen voor genoemd. Een deel van de professionals geeft aan dat de opleiding 'al streeft naar inclusie' en vindt een gesprek hierover met elkaar of met studenten niet zinvol. Het zou de ongelijkheid slechts in de hand werken.

We zeggen hier heel bewust tegen elkaar: 'We zijn inclusief.' We willen voorkomen dat er een self fullfilling prophecy ontstaat. Het is hier nooit een gespreksitem dat studenten met een migratieachtergrond minder kansen hebben. Het is voor het eerst dat ik ervan hoor dat dat zo is. (professional rechten) 
Onze overkoepelende visie is 'van hbo'ers mag zelfstandigheid en problem ownership worden verwacht.' Studenten worden gelijk behandeld, alleen voor langstudeerders is er extra aandacht. (professional, economie)

Over discriminatie spreken we niet in ons team, wel over een inclusief curriculum. (professional, economie)

Hiertegenover staat een groep onderwijsprofessionals die aangeeft zich zorgen te maken over ongelijke kansen van studenten met en zonder migratieachtergrond. Ook zij geven aan hun zorgen nauwelijks te bespreken met het team en alleen met individuele collega's het gesprek aan te gaan. Enkele geïnterviewden noemen het 'onveilig' om het over ongelijkheid en discriminatie te hebben, vanwege (enkele) collega's die er weinig voor open staan of ontkennen dat er sprake kan zijn van discriminatie.

Ik krijg soms plaatsvervangende schaamte als ik het erover heb met collega's. Hoe kun je inclusief zijn als je niet naar iemands achtergrond kijkt, niet weet wie je voor je hebt? (professional, economie)

Het is een blinde vlek: 'We behandelen hier iedereen gelijk'. Punt. Docenten zijn er meer op gericht zichzelf te beschermen tegen de student, dan kritisch naar zichzelf te kijken. (professional, rechten)

Ten slotte heeft een aantal onderwijsprofessionals aangegeven dat over het feit dat de studentenpopulatie steeds diverser wordt, negatief wordt gedacht door enkele collega's. Dit zou meestal impliciet en onbewust worden geuit. Dit signaal is afgegeven door medewerkers van twee van de vijf teams, die deelnamen aan het onderzoek.

Van alle geïnterviewde onderwijsprofessionals geeft slechts een klein deel aan'wel eens klachten van studenten' over discriminatie door stagebedrijven te hebben gehad. Of dat een reële indicatie is van de mate van discriminatie die de studenten ondervinden, valt te betwijfelen. Een docente schetst dat, mede door de omvang van haar opleiding, het contact met studenten te beperkt is om een vertrouwensbasis op te bouwen. Haar analyse dat de professionals onvoldoende weten of er sprake is van discriminatie wordt gedeeld door circa een derde van de geïnterviewden professionals.

We kennen de studenten niet goed genoeg. We zijn een te grote opleiding daarvoor. Maar het is niet alleen een haalbaarheidsprobleem, het is ook de visie 'de noodzaak van het zelfstandig zoeken'. (professional rechten)

Twee professionals - beiden met een migratieachtergrond - gaven expliciet aan dat discriminatie een fact of life is en dat de student met migratieachtergrond 'gewoon' harder moet werken om gelijke kansen te hebben. Dit zouden zij ook meegeven in hun begeleidingsgesprekken met studenten. Beiden hebben tijdens het interview verteld 
niet met collega's over dit onderwerp te willen spreken, omdat zij zich onvoldoende begrepen voelen door collega's.

Uit eigen ervaring weet ik dat het niet openlijk gebeurt. Het sollicitatiegesprek zit zo vol vooroordelen. Er werd aan mij niets gevraagd over mijn kennis, maar wel of ik lid was van een studentenvereniging ... Ik heb niet de behoefte om dit aan te kaarten bij collega's, het wordt al snel als lastig of gezeur ervaren. (professional, rechten)

Dit soort onderwerpen zitten niet heel sterk in ons DNA. We zijn zakelijk. Als ik er over zou beginnen verwacht ik zuchtende reacties, zo van 'we moeten al zo veel'. Het is net als politiek een gevoelig onderwerp. (professional, economie)

\subsubsection{Toegang tot de arbeidsmarkt; kwetsbare groepen}

De onderwijsprofessionals zien verschillende groepen die moeite hebben om toegang te krijgen tot stages. Dat zijn: studenten zonder netwerk in het beroepenveld, studenten die weinig assertief zijn en langstudeerders. In deze groepen zitten studenten met en zonder migratieachtergrond, maar het vermoeden ${ }^{16}$ is dat de studenten met migratieachtergrond in deze groepen oververtegenwoordigd zijn.

Onderwijsprofessionals merken op dat een groot deel van de hbo-studenten van de eerste generatie - met en zonder migratieachtergrond - geen functioneel netwerk heeft in het beroepenveld waartoe zij opleiden (zie verder 5.3.3).

Wij hebben een algemene studie, dat trekt veel studenten die nog niet weten wat ze willen. Ook van buiten de stad. Het gros van de ouders heeft niet gestudeerd. Veel studenten zijn bescheiden, hoewel de student met een Nederlandse achtergrond vaak wel iets directer is. Ze moeten allemaal opgevoed worden in 'hoe gedraag je je als je iets niet weet en hoe vraag je hulp?' Stages zoeken gebeurt vooral in eigen netwerk, ik zie geen verschil in toegang, wel gaan de afgestudeerden met een migratieachtergrond iets meer richting eigen bedrijven. (professional, economie)

Kwetsbaar zijn ook de studenten die niet assertief zijn en niet tijdig hulp durven vragen, zien de professionals. Ook dit kenmerk herkennen onderwijsprofessionals bij studenten met alle achtergronden, maar iets vaker bij bepaalde groepen met een niet-westerse achtergrond (zie verder 9.3.4).

Ten slotte hebben de studenten met studievertraging moeite met het vinden van een afstudeerstage, zij missen ondersteuning en contact met docenten doordat zij iets langer het reguliere studieprogramma doorlopen. In de groep langstudeerders zitten

16 Even klein deel van de geïnterviewden meent dat er geen sprake is van oververtegenwoordiging van studenten met migratieachtergrond bij de langstudeerders. De opleidingen hebben hierover geen data beschikbaar. 
naar verhouding veel studenten met (financiële) zorgtaken en een niet-westerse achtergrond.

\subsubsection{Verschillen in stage- en netwerkervaring}

Onderwijsprofessionals zien dat studenten met en zonder migratieachtergrond tijdens hun studie niet altijd in gelijke mate ervaringen en contacten met het werkveld opbouwen. Dat begint soms al bij de meeloopstages, die vaak via het eigen netwerk worden gevonden. De studenten met een Turkse achtergrond vallen in dit kader op omdat zij volgens onderwijsprofessionals, vaker dan andere studenten, een meewerkstage bij kleine bedrijven lopen van mensen uit hun Turkse Nederlandse netwerk.

De begeleiding door stagebedrijven die gevonden worden in de eigen sociale omgeving laat soms nog wel te wensen over, signaleren stagecoördinatoren. Dat laatste geldt volgens hen ook voor een deel van de stagebedrijven die stagiaires 'inzetten' als reguliere werknemers. De stagiaires krijgen weliswaar een vergoeding en draaien volledig mee, vaak op een te laag niveau, maar worden nauwelijks begeleid. Vanwege de vergoeding kiezen juist studenten uit sociaaleconomisch moeilijke omstandigheden voor dit type stagebedrijf. Op verschillende opleidingen zijn de regels om deze reden inmiddels aangescherpt.

De eerste stage is maar een paar weken en mag bij familie. Maar de keuze voor een stage bij familie maakt het daarna wel weer moeilijker om een goede meewerkstage te vinden en daarmee dus ook een afstudeeropdracht. (professional, economie)

Allochtone studenten komen bij allochtone kantoren, dat beeld klopt wel. Maar ook bij de politie en de IND. Maar ik zie ook dat minder goede studenten op minder goede plekken komen, waar ze dan wel een vergoeding betalen. Voor die kantoren zijn de studenten gewoon goedkope werkkrachten op mbo-niveau. Zo'n bedrijf is tevreden, maar de werkzaamheden hebben een te laag niveau voor de student. Loop je stage op een slechte plek waar ze niet genoeg begeleiden of geen inhoudelijk werk bieden, dan heeft dat een negatieve invloed op je arbeidsmarktkansen. Nederlandse studenten komen voor zichzelf op, die gaan daar weg. Allochtone studenten houden vol. Dan wordt de stage uiteindelijk niet goedgekeurd door de opleiding en gaan ze vechten met de opleiding. (coördinator stages, rechten)

Via stages, gastsprekers en (netwerk)activiteiten van de opleiding kunnen studenten hun netwerk uitbouwen en bekend raken met de codes in het werkveld. Echter, doordat deze activiteiten vaak buiten het curriculum vallen, nemen studenten met sociaaleconomisch de minst gunstige uitgangspositie en de grootste ondersteuningsbehoefte slechts beperkt deel aan deze activiteiten. Vanwege (financiële) zorgtaken volgen deze studenten - waaronder naar verhouding veel studenten met een migratieachtergrond in de regel alleen de verplichte onderdelen van de opleiding. 
Het valt op dat studenten met een niet-westerse achtergrond bij een netwerk direct denken aan familie en wederkerigheid, terwijl het gaat om activiteiten bijwonen en zakelijke contacten vanuit je bijbaan of eerdere stages onderhouden. (professional, rechten)

\subsubsection{Verschillen in hulp vragen}

Zelfstandigheid is een kenmerk van studeren op hbo-niveau, deze boodschap klinkt door in vrijwel alle gesprekken met onderwijsprofessionals. Net als 'wanneer de stage niet lukt, dan moet de student het zelf tijdig aangeven'. Inschakelen van hulpbronnen, tijdig en adequaat aangeven als iets niet lukt en vragen stellen zijn belangrijke aspecten van de veel genoemde hbo-zelfstandigheid. En precies op deze aspecten zien onderwijsprofessionals verschillen tussen de studenten.

Eerste generatie studenten en studenten met een migratieachtergrond hechten erg aan een beeld van zichzelf dat ze het zelf kunnen en geen hulp nodig hebben, legt een docente uit. Zij signaleert net als verschillende collega's dat het voor studenten met een niet-westerse achtergrond minder vanzelfsprekend is om voor zichzelf op te komen en tijdig aan de bel trekken op een assertieve manier. Genoemde obstakels zijn bescheidenheid, vaak bij vrouwelijke studenten, en bij de mannen juist trots.

Nee, ik zie niet dat niet-westerse studenten langer zoeken naar een stage. Ik krijg hier meer Nederlandse jongens aan mijn bureau die het niet lukt. (coördinator stages, economie)

Een deel van de professionals waarschuwt in dit kader om studenten met een migratieachtergrond niet als een homogene groep te beschouwen.

Ik heb het idee dat de studenten met een migratieachtergrond juist te vinden zijn bij de uitersten onder de studenten, dus ofwel bij de studenten met een gigantische drive, dus bij de studenten met een focus die echt alles goed doen, ofwel juist bij de zwakkere studenten. (professional, economie)

Zelfvertrouwen is zeker in ons werkveld heel belangrijk, maar ik zie juist bij de niet-westerse studenten heel erg zelfbewuste mensen die met een open en nieuwsgierige blik naar de wereld kijken en zeggen: 'Hier ben ik!' Daar zit de afgelopen 15 jaar echt wel verandering in. (professional economie)

Een professional met een niet-westerse achtergrond adviseert om ook onderscheid te blijven zien tussen studenten met een niet-westerse achtergrond die hier zijn geboren en getogen en de nieuwkomers. Die laatste groep heeft vaker een taalachterstand en heeft vergeleken met andere studenten meer zorgtaken voor de familie, dan hier geboren studenten met een migratieachtergrond.

Geen van de onderwijsprofessionals beschikt over 'harde gegevens' over het taalniveau van de studenten. Een deel van de docenten meent dat het taalniveau van hbo'ers met 
een migratieachtergrond beduidend minder is dan dat van hbo'ers met een Nederlandse achtergrond. Anderen geven aan dit niet te zien of zien zelfs een tegenovergesteld beeld. Dit gebrek aan gedeeld beeld van de taalproblematiek is opvallend, omdat verschillen in taalbeheersing door een deel van de onderwijsprofessionals juist als belangrijke verklaring voor het verschil in arbeidsmarktpositie is aangedragen.

\subsection{De werkgevers aan het woord}

\subsubsection{De werkgevers over (on)gelijke kansen}

In de volgende paragraaf beschrijven we het perspectief van de geïnterviewde werkgevers, directieleden en HR-medewerkers (verder: werkgevers). Wat is hun beeld van de (on)gelijke toegang tot de arbeidsmarkt, mogelijke verklaringen voor de verschillen en hun eigen ervaringen met diverse groepen sollicitanten, stagiaires en starters? Een deel van de werkgevers herkent het beeld dat er kansenongelijkheid bestaat, op de arbeidsmarkt als geheel en in de eigen sector. Zij merken op dat hun werkomgeving, de eigen organisatie of sector, erg homogeen is. Als signaal van kansenongelijkheid noemen ze de negatieve sollicitatie-ervaringen van hun goed gekwalificeerde stagiaires en collega's met niet-westerse achtergrond.

"Het valt ons op dat onze niet-westerse collega's tijdens hun loopbaan vaak zijn afgewezen. We hebben net een gesprek gehad met een geweldige nieuwe collega met een Turkse achtergrond. Wij zijn een klein advocatenkantoor, dus wij waren om die reden niet haar eerste keuze. Maar ze was bij de grote kantoren overal afgewezen omdat ze niet voldoende werkervaring zou hebben. En dan heb je het over een talent dat twee masters op zak heeft, je moet toch ergens een kans krijgen om die werkervaring op te doen?' (professional in de juridische sector)

"Ik kan de onderzoeksvraag goed plaatsen, het is zeker het geval dat studenten met een migratieachtergrond meer moeite hebben, zowel vanuit het hbo als WO. We krijgen bijvoorbeeld last-minute sollicitaties binnen van studenten die nergens anders terecht kunnen, terwijl ze heel goed gekwalificeerd zijn en allang een stageplaats zouden moeten hebben." (professional in de juridische sector)

"Twee keer per jaar loopt er iemand stage bij ons. We worden dan gebeld door de school, en dan gaat het vaak om een kandidaat met migratieachtergrond die nog niets heeft kunnen vinden. Die wordt dan altijd wel aangenomen." (professional in de private sector)

Ook herkennen de meeste werkgevers die wij gesproken hebben dat de overstap van studie naar werk moeilijk kan zijn, zowel voor studenten met een migratieachtergrond als voor studenten met een Nederlandse achtergrond. Dit is dan ook mede een motivatie voor een deel van de organisaties om juist wel stages aan te bieden en zo kansen 
te creëren om de overstap gemakkelijker te maken, zeker in het geval van publieke organisaties zoals gemeenten maar ook bij kleinere ondernemingen.

\subsubsection{Discriminatie bij werving en selectie}

De meerderheid van de geïnterviewde werkgevers denkt dat discriminatie op grond van herkomst plaatsvindt, in hun sector of op de arbeidsmarkt als geheel, maar zegt geen (recente) voorbeelden te hebben uit de eigen organisatie. Enkele geïnterviewde werkgevers menen wel dat er sprake is van onbewuste vooroordelen tijdens besluitvormingsprocessen bij sollicitaties, ook binnen hun eigen organisaties. Een enkele respondent heeft zelf expliciete discriminatie meegemaakt in een vorige functie als recruiter, toen hij het verzoek kreeg om op herkomst te selecteren. Dit ging weliswaar niet specifiek over hbo-studenten of starters, maar geeft volgens de respondent wel de bestaande cultuur in een deel van de bedrijven aan.

"Als je het over kansengelijkheid hebt... Er wordt echt gediscrimineerd, er wordt naar een specifieke afkomst gevraagd. En als ik kijk hoe er dan gereageerd werd, bij de recruiters, dan werd er toch nog over gediscussieerd hoe we hier dan mee om moesten gaan. Dan was dus niet meteen duidelijk dat je dat niet moest doen." (professional bij een gemeente)

Andere geïnterviewde werkgevers hebben geen concrete ervaring met discriminatie, maar vermoeden wel dat een deel van hun branche, in dit geval de advocatuur, niet open staat voor mensen met een migratieachtergrond. Het gaat hier met nadruk om specifieke 'traditionelere' kantoren, benoemen zij. Zo wordt bij internationaal opererende kantoren diversiteit juist aangemoedigd en kan diversiteit bij grotere kantoren ook een onderwerp zijn waarmee organisaties zich positief proberen te onderscheiden.

\subsubsection{Wijze van sollicitatie}

De geïnterviewde werkgevers vinden het moeilijk om verklaringen te geven voor het verschil in toegang tot de arbeidsmarkt. Zij koppelen de verschillen tussen afzonderlijke sollicitanten niet aan het al dan niet hebben van een migratieachtergrond. Ze benoemen wel een aantal factoren die verklaren waarom de ene sollicitant succesvoller is dan de ander, en die deels wat vaker terug blijken te komen bij studenten met een migratieachtergrond. Hieronder geven we een aantal punten per selectiefase weer, waarvan de meeste een rol spelen bij zowel stageplaatsen als reguliere banen.

Werkgevers en HR-medewerkers zijn in het algemeen vaak niet te spreken over de kwaliteit van sollicitaties van hbo'ers voor stages en startersbanen. De geïnterviewde werkgevers geven aan dat zij veel sollicitaties ontvangen die niet aansluiten bij de functie, die niet volledig zijn en die veel slordige fouten bevatten in de tekst of in de opmaak. De slordigheid van de sollicitaties houdt volgens de geïnterviewde werkgevers geen verband met de migratieachtergrond van de sollicitanten. 
Verschillende werkgevers vermoeden dat studenten niet goed weten wat er tijdens een sollicitatiegesprek van hen wordt verwacht. Zij constateren dat studenten zich niet goed voorbereiden, of niet goed worden voorbereid op bijvoorbeeld het tonen van motivatie en het stellen van vragen over het bedrijf en de functie. Hoewel zij dit waarnemen bij studenten met en zonder migratieachtergrond, menen zij te zien dat studenten met een migratieachtergrond zich vaker bescheiden en terughoudend opstellen. Werkgevers zonder migratieachtergrond beoordelen een sollicitant met open houding als positief, vertellen recruiters (Box 5.3)

\section{Box 5.3 Terughoudendheid bij sollicitatiegesprekken}

Verschillende werkgevers constateren dat sollicitanten met een migratieachtergrond zich terughoudender opstellen dan sollicitanten met een Nederlandse achtergrond wanneer zij op gesprek komen voor een stage of een reguliere baan. Deze terughoudendheid heeft betrekking op de algemene presentatie en specifiek op een afwachtende houding tijdens het gesprek en het niet stellen van vragen aan de werkgever. Dit punt is onder andere naar voren gebracht door een HR-medewerker die zelf een migratieachtergrond heeft.

"Het duurt een tijdje totdat je de rituelen snapt. Je moet een tijd lang observeren, kijken hoe het werkt, voordat je eraan deel kan nemen. Dit geldt bij sollicitaties, bij het netwerken, maar geldt ook voor omgangsvormen, waaronder bijvoorbeeld het stellen van vragen." (professional in de private sector)

Een recruiter ziet dat wat een sollicitant uit beleefdheid doet bij een werkgever zonder migratieachtergrond kan overkomen als een gebrek aan assertiviteit. Voor een deel lijkt dit misverstand volgens de respondenten te verklaren door cultureel bepaalde gedragsnormen. Dat neemt niet weg dat een groot deel van de studenten, met en zonder migratieachtergrond, volgens de werkgevers baat zou hebben bij een minder afwachtende houding en ondersteuning van de opleiding op dit punt.

"Assertiviteit is een algemeen punt, niet alleen bij studenten met migratieachtergrond. Daar zit eigenlijk geen verschil tussen. Ook bij studenten van Nederlandse komaf zou de assertiviteit omhoog mogen." (professional in de juridische sector)

De meeste werkgevers bevestigen dat het taalniveau over het algemeen een aandachtspunt is bij hbo-studenten, zeker in de juridische wereld die als 'talig' wordt omschreven. Er is echter onenigheid over de vraag of dit een groter probleem is bij studenten met een migratieachtergrond dan bij studenten zonder migratieachtergrond. 
"De advocatuur is een talige wereld, bedrijven haken af als je een fout maakt. Het klopt dat het taalniveau lager is bij studenten met een migratieachtergrond, dat zie je ook echt bij de advocatuuropleiding. Maar je kunt er wel wat aan doen. Je moet gewoon extra training opzetten, het is wel op te lossen." (professional in de juridische sector)

"Taal is echt geen punt. Als het al een punt is, dan zijn studenten met een migratieachtergrond beter in taal dan studenten zonder een migratieachtergrond. Het is waar dat de advocatuur een talige omgeving is, dus het is belangrijk. Maar dat geldt voor iedereen. En iedereen moet dat dan nog leren, dat gebeurt on the job. Er mag wel over het algemeen meer aandacht voor zijn." (professional in de juridische sector)

Een geïnterviewde HR-medewerker met een migratieachtergrond herkent de discussie. Hij geeft aan dat het niet zo zeer gaat om correcte taal of het maken van fouten, maar om de juiste toon, de goede uitdrukkingen en andere taalcodes. Uit persoonlijke ervaring weet hij dat het voor studenten met een migratieachtergrond moeilijk kan zijn om aan te sluiten bij de taal en het vocabulaire in het werkveld als zij dit niet van huis uit mee hebben gekregen.

\section{Box 5.4 Ongerichte sollicitatiebrieven}

Werkgevers geven aan dat zij veel ongerichte sollicitaties ontvangen, zowel in de vorm van een open sollicitaties als reactie op vacatures. Het gaat om sollicitaties waarbij de tekst zo algemeen is dat het voor veel vacatures geschikt zou kunnen zijn. Ook al durven de respondenten hier geen harde uitspraken over te doen, toch hebben zij de indruk dat de ongerichte sollicitaties vaker afkomstig zijn van sollicitanten met een migratieachtergrond. Werkgevers vermoeden dat sollicitanten met een migratieachtergrond meer sollicitaties versturen om daarmee hun kansen te vergroten.

Ongerichte en gestandaardiseerde sollicitaties maken volgens werkgevers echter weinig kans (zie voorgaande hoofdstuk). Voor selecteurs is het heel belangrijk dat uit de sollicitatie een goed begrip van de aansluiting op de functie naar voren komt en dat sollicitanten hun competenties en toegevoegde waarde voor de organisatie onder het voetlicht weten te brengen.

Waar let ik op? Begrip van de functie. Is die brief echt naar de functie geschreven? Of is het een standaardbrief? Dat is zo zonde. We hebben zo veel vacatures en dan zie je dat mensen twee keer solliciteren. Dat zie ik over de hele breedte, maar zeker ook bij deze doelgroep." (professional bij een gemeente)

Zeker bij een studie als hbo-rechten vinden recruiters het belangrijk dat studenten duidelijk maken wat ze in vaardigheden, ervaring en kennis meebrengen en waarom de 
organisatie daarvan kan profiteren. Een recruiter geeft aan hier niet alleen een probleem, maar vooral ook kansen te zien. Een student die duidelijk kan maken welke studiekeuzes hij of zij heeft gemaakt en waarom, welke persoonlijke ervaring hij meebrengt, en hoe dit allemaal aansluit bij de functie waar hij op solliciteert, kan zich juist positief onderscheiden van andere hbo-sollicitanten.

"Het gaat ook over het verhaal op een goede manier vertellen. Bijvoorbeeld over nevenactiviteiten. Daar wordt veel op gelet bij advocatuur, dus bestuursfuncties etc. Als studenten nog thuis wonen en daarnaast veel hebben gewerkt in bijbanen, dan hebben ze vaak geen nevenfuncties gehad. Om een kans te maken moeten ze vertellen dat ze juist andere vaardigheden hebben opgebouwd, een sterk verhaal neerzetten over wat ze wél hebben gedaan." (professional in de juridische sector)

\subsection{Samenvatting}

In dit hoofdstuk staat beschreven in hoeverre de hbo-studenten (ook wel'de hbo'ers) en de professionals uit het onderwijs en het werkveld het vraagstuk van ongelijke arbeidsmarktkansen herkennen en wat volgens hen de verklarende factoren zijn. De meeste studenten herkennen het vraagstuk van ongelijke toegang, vooral tijdens schriftelijke sollicitaties, waarvan er veel onbeantwoord blijven of worden afgewezen. Kandidaten met een migratieachtergrond worden daar vaker mee geconfronteerd dan kandidaten zonder migratieachtergrond. Terwijl de ene groep studenten met een migratieachtergrond aangeeft de vele mislukte sollicitatiepogingen te hebben ervaren als een bevestiging van ongelijke kansen en zich onzekerder is gaan voelen gedurende de studie, geeft een ander deel van de studenten met migratieachtergrond aan de signalen bewust te negeren, om daarmee vertrouwen te houden in de eigen kansen.

Een klein deel van de hbo'ers met een migratieachtergrond heeft verteld over discriminatie tijdens sollicitatiegesprekken (verplicht afdoen van de hoofddoek en denigrerende opmerkingen). De helft heeft dit niet gemeld bij de opleiding vanwege lage verwachtingen over het effect hiervan ('de opleiding kan niets doen') of uit angst dat zij door het melden vertraging oplopen.

De hbo'ers noemen nog meer factoren die bijdragen aan een ongelijke arbeidsmarktpositie: hbo'ers met een migratieachtergrond krijgen minder vaak financiële ondersteuning van hun ouders, lenen minder en werken om die reden meer naast hun studie. Ze hebben vaker werkervaring (bijbanen) buiten het beroepenveld, wat volgens afgestudeerden uiteindelijk leidt tot een minder relevant cv. Verder zou een deel van de hbo'ers met een migratieachtergrond een bescheiden presentatie hebben die minder aansluit bij verwachtingen van werkgevers met een Nederlandse achtergrond. Ten slotte benoemen hbo'ers met een migratieachtergrond dat zij tijdens hun studie onzekerder zijn geworden door vele mislukte sollicitatiepogingen. Ook de kritiek van docenten op hun taalniveau maakt hen onzeker over hun kansen. De hbo'ers merken op dat een lager vertrouwen in de eigen kansen negatief doorwerkt tijdens sollicitaties. 
Onderwijsprofessionals hebben geen gedeeld beeld van de mate waarin hun studenten met een migratieachtergrond te maken krijgen met ongelijke kansen. Ook zijn de meningen verdeeld over de oorzaken hiervan. Terwijl een deel de verklaring vooral zoekt bij de studenten (o.a. verschil in taalniveau), leggen anderen de oorzaak bij de werkgevers (voorkeuren en discriminatie) en bij de ongelijke startpositie (zorgtaken, bijbanen, onzekere presentatie). Over het onderwerp ongelijke kansen en discriminatie bij stages en werk wordt onderling weinig gesproken. Vrij unaniem denken onderwijsprofessionals dat het netwerk mede verklarend is voor verschillen in toegang: studenten met een Nederlandse achtergrond komen door een sterker netwerk gemakkelijker aan een stage en werk.

De geïnterviewde werkgevers en HR-medewerkers herkennen dat er sprake is van ongelijke toegang op de arbeidsmarkt, maar zien dat in de eigen organisaties op dit moment niet. De publieke en private bedrijven die deelnamen aan dit onderzoek zijn nu juist op zoek naar divers talent. Enkele werkgevers geven aan dat zij in het verleden (in eigen of andere bedrijven) hebben meegemaakt dat een kandidaat zonder migratieachtergrond voorrang kreeg. De werkgevers geven aan weinig duidelijke verschillen te zien tussen groepen met en zonder migratieachtergrond die de ongelijke arbeidsmarktpositie kunnen verklaren. Het enige concrete verschil dat is benoemd door de werkgevers is het gebruik van effectieve sollicitatiemethoden. De indruk bestaat dat kandidaten met een migratieachtergrond inzetten op het versturen van een groot aantal sollicitatiebrieven en dat zij vaker ongerichte of open sollicitaties versturen. Juist deze methode is volgens werkgevers weinig kansrijk. Ook beschouwen de werkgevers een te bescheiden presentatie of 'overcompensatie' in schriftelijke sollicitatiebrieven als weinig kansrijk en menen zij dit juist vaker te zien bij onzekere kandidaten (met een migratieachtergrond).

Een verklaring voor de indruk dat het netwerk van de hbo'ers zonder migratieachtergrond sterker is (genoemd door zowel hbo'ers als hbo-professionals) vinden we op basis van de gesprekken met werkgevers niet. Een analyse van de hbo'ers en hun gevonden stages en werk ${ }^{17}$ laat zien dat alle eerste generatie studenten, ook degenen met een Nederlandse achtergrond, een beperkt netwerk hebben in het beroepenveld van de studies. Het netwerk is wel van invloed als het gaat om het vinden van hulp bij het schrijven van brieven en cv's en het aanleren van 'taalcodes'. Daar zijn degenen met taalvaardige ouders in het Nederlandse in het voordeel.

17 De onderzoekers hebben de wijze waarop alle geïnterviewde hbo'ers hun stages (en werk) hebben gevonden geanalyseerd. Zie schema in Bijlage 4. 


\section{Factoren die (gelijke) kansen op stage en werk versterken}

We vroegen aan alle respondenten die deelnamen aan het kwalitatieve deel van het onderzoek wat er volgens hen nodig is voor een goede overgang naar de arbeidsmarkt. Paragraaf 6.1 opent met de ervaringen van hbo'ers en hun suggesties voor gelijke arbeidsmarktkansen. Daarna beschrijven we in paragraaf 6.2 wat de onderwijsprofessionals hierover hebben verteld en we sluiten af met de voorstellen die zijn gedaan door professionals uit het werkveld van de opleidingen. In dit hoofdstuk hebben we de voorstellen, die specifiek zijn gericht op het vergroten van kansen van sollicitanten met een migratieachtergrond, in een box geplaatst.

\subsection{De hbo'ers aan het woord}

\subsubsection{Docent-student contact}

Als het gaat om het versterken van arbeidsmarktkansen zijn er een aantal algemene punten genoemd waarover alle studenten en alumni het eens zijn. Het belang van positief en persoonlijk contact tussen studenten en docenten is zo'n punt. Geïnterviewde hbo'ers met een positief contact met docenten of begeleiders zijn opvallend gemotiveerd en voelen zich gewaardeerd tijdens hun studie.

Bij mijn begeleider heb ik echt het gevoel dat ze uit haar hart werkt, en dat haar doel is dat $i k$ zal slagen. Bij veel medewerkers heb ik dat gevoel niet. Het is erg belangrijk voor de motivatie. Bij gebrek hieraan door docenten snap ik dat studenten gefrustreerd en gedemotiveerd raken. Mijn begeleider gaf feedback, maar draaide het om in iets positiefs om aan te werken. (studente rechten, Turkse achtergrond)

En dan zit je hier op een hele kleine school en vanaf dat moment werd ik wel steeds blijer. Het zijn kleine klassen, docenten die je kennen, mensen spreken elkaar aan met de voornaam, er was contact, we werden als volwassenen behandeld. Je krijgt meer vertrouwen. Ik heb ontdekt dat ik het voor mezelf moest doen en ik werd bijvoorbeeld lid van de MR. Dit is een omgeving waarin dat kan, waarin dat wordt gewaardeerd. Het is een ideale plek om jezelf te ontwikkelen en het is ook heel vervelend, want in de wereld buiten de opleiding is niks zo, dan staat er niemand voor je klaar. Hoe doe ik het zelf? Daar maak ik me dan wel zorgen om. (student rechten, Poolse achtergrond) 
Individuele aandacht en kleinschalige activiteiten, zoals kleine mentorgroepen, zijn volgens geïnterviewde hbo'ers ook belangrijk om de studenten met financiële zorgen in beeld te krijgen. In het vorige hoofdstuk is door onderwijsprofessionals benoemd dat studenten met een migratieachtergrond opvallen, omdat zij vaker (te) laat hulp vragen en dat dit deels verband lijkt te houden met schaamte en een minder sterk vertrouwen in de geboden hulp. Het hebben van een 'vertrouwensband' met (een of meerdere professionals van) de opleiding is door hbo'ers in dit kader vaker genoemd als voorwaarde om eerder hulp te vragen.

School zou een community moeten zijn, waarin je een vertrouwensband hebt, waar professionals inzicht hebben in behoeften en contact hebben met zorg, schuldhulp en huisvesting. En studiefinanciering voor studenten die moeten studeren zonder hulp van hun ouders, zoals nieuwkomers. Waar haal je de tijd vandaan om dat als student allemaal te regelen? Ik heb zelf studiefondsen gevonden. Sommige studenten stoppen met school omdat ze niet weten dat deze hulpmiddelen bestaan. (afgestudeerde rechten, Congolese achtergrond)

Zodra je wat meer betrokken bent bij de opleiding, heb ik het idee dat je eerder die stage krijgt die je zou willen. Als je veel interactie hebt met je docenten, dan hebben die vaak wel in hun netwerk iemand die ze aan je kunnen koppelen. Ik heb bijvoorbeeld geholpen met de introductie van eerstejaars waardoor je contact krijgt met docenten en daardoor kon ik ook bij mijn eerste stage en werkgever aan de slag... Thuis voelen op de opleiding is denk ik voor die groep anders. Studenten met een migratieachtergrond waren minder betrokken, ik denk vooral omdat ze vaak nog harder naast hun studie moesten werken om hun hoofd boven water te houden. (afgestudeerde rechten, Nederlandse achtergrond)

Afgestudeerden met een migratieachtergrond geven aan dat diversiteit onder professionals in het onderwijs en het werkveld bijdraagt aan het vertrouwen in de eigen arbeidsmarktkansen. "Als je op een website van een bedrijf niemand ziet die op je lijkt, dan is het moeilijker om erop te vertrouwen dat je een gelijke kans krijgt", verwoordde een van de studenten (box 6.1).

\section{Box 6.1 Diversiteit en rolmodellen}

Weten welke kant je op wil na het afstuderen, vinden veel studenten moeilijk. Op dit punt verschillen studenten met en zonder migratieachtergrond weinig van elkaar. Maar als er op school en in het werkveld nauwelijks sprake is van diversiteit, is nadenken over de toekomst nog moeilijker, vertellen hbo'ers met een migratieachtergrond. Verschillende studenten geven aan meer een-op-een hulp nodig te hebben bij de 'wat wil ik vraag'. Op basis daarvan kunnen ze beter worden geholpen bij het zoeken van passende stages.

Zelfreflectie is leuk, maar hoe kan ik weten wat ik wil, als ik niet weet wat er is en geen voorbeelden ken in mijn omgeving? (student rechten, Marokkaanse achtergrond) 
Terugkijkend op hun studieperiode menen afgestudeerden met een migratieachtergrond dat het hen had geholpen wanneer zij meer (individuele) gesprekken met docenten en vertegenwoordigers van bedrijven met een migratieachtergrond hadden gehad. De hbo'ers beschrijven verschillende contexten (zoals docententeam, bedrijvendagen, stageplekken) waar zij zich niet konden herkennen in de professionals.

Studenten benoemen verder dat de opleidingen veel inzetten op persoonlijke ontwikkeling en reflectie, terwijl volgens hen voor de 'basisbehoeften' - stage en inkomen geen hulp is (Box 6.2)

Ik had gewild dat de uren die gereserveerd waren voor gesprekken met loopbaanbegeleiders beter waren gebruikt. Die uren hadden kunnen worden voor sollicitatietrainingen. En er lag best veel focus op reflectieverslagen, best nuttig, maar moet er zo veel focus op liggen? Ja kan beter tijd besteden aan de individuele begeleiding van studenten die geen stage vinden (afgestudeerde economie, Marokkaanse achtergrond)

Wat beter kan? Meer naar individuele mensen kijken. Focus op mensen die geen stage kunnen vinden. Ze laten de mensen los die een stage hebben gevonden, maar die zouden ze ook kunnen betrekken bij degenen die nog niets hebben gevonden. Waarom moet iedereen het individueel doen? Waarom niet samen? Waarom niet flexibeler? (afgestudeerde economie, Marokkaanse achtergrond)

We werden niet ondersteund. Ze hadden je in contact kunnen brengen met bedrijven, of een stage kunnen toewijzen bij de hogeschool zelf. Nee, ook studenten die niks konden vinden. Die waren echt klaar. En tijdens de stage? Heel slecht eigenlijk. Je moest zelf achter de begeleiding aan en smeken dat ze je stukken lazen. Er werd heel erg veel eigen initiatief verwacht (afgestudeerde economie, Nederlandse achtergrond)

\section{Box 6.2 Meer steun bij stage}

De overgrote meerderheid van de studenten met en zonder migratieachtergrond, geeft aan dat zij in de aanloop van het zoeken van een stage meer begeleiding hadden kunnen gebruiken. Om een stage te vinden die beter aansluit op de eigen ambities en om het vertrouwen in arbeidsmarktkansen niet te verliezen. Vooral studenten die - ondanks inspanningen - niets vinden, hebben volgens geïnterviewden meer support nodig van de opleiding. Dit is vaker het geval bij studenten met een migratieachtergrond. 
Op basis van de interviews kunnen we voorzichtig concluderen dat de opleidingen de laatste jaren meer aandacht zijn gaan besteden aan de behoeften van individuele studenten. Studenten van de economische opleidingsrichtingen zijn over het algemeen positiever over de beschikbare begeleiding dan de afgestudeerden van diezelfde richting.

Je wordt na de studie in het diepe gegooid. Studenten kwamen moeilijk aan een baan, omdat bedrijven om meer werkervaring vragen. Dus bijna alle afgestudeerde studenten startten bij een detacheringsbureau. Dat was echt niet fijn, omdat je dan opnieuw weer moet leren en werken. (afgestudeerde economie. Antilliaanse achtergrond)

\subsubsection{Ontmoeting met werkgevers tijdens studie}

De opleidingen organiseren jaarlijks een dag waarop studenten en professionals uit het beroepenveld elkaar kunnen ontmoeten. Alle respondenten (studenten, onderwijs en werkveld) die te maken hebben gehad met deze dagen zijn er opvallend positief over. Het biedt studenten en bedrijven een mogelijkheid om elkaar te ontmoeten en met elkaar in gesprek te gaan. Onderstaande citaten illustreren de positieve ervaringen met dit type bijeenkomsten en laten tevens zien dat een jaarlijkse bijeenkomst wat betreft de studenten niet voldoende is.

Mijn school heeft een stagemarkt georganiseerd. Wij hebben de mogelijkheid gekregen om onze CV en/of sollicitatiebrief bij bedrijven af te geven, zodat we via deze weg een stage konden bemachtigen. Sommige studenten hebben hierdoor zelfs al een stage gevonden. De opleiding heeft studenten goed voorbereid op de arbeidsmarkt door stagemarkten te organiseren en ons op de hoogte te stellen van Meet \& Greets. Dit zouden zij vaker moeten doen. (studente rechten, Marokkaanse achtergrond)

Het goede van de stagebeurs is dat het allemaal bedrijven zijn die heel serieus met stagiairs omgaan, het zijn vaak maatschappelijk betrokken bedrijven. Veel betrokkener dan de bedrijven die hun stages op Stageplaza of een andere marktplaats gooien. (student economie, Nederlandse achtergrond)

Aan het begin van de opleiding hadden we veel Personal Branding, super goed! Dat liet je inzien wie je was, wat je uniek maakt en wat de mogelijkheden zijn na deze opleiding. Dit was een korte kennismaking met enkele opties die mogelijk waren na de opleiding. Helaas was dit alleen in de eerste twee jaar. Mijns inziens kan dit verder uitgebreid worden. Bijvoorbeeld middels testen, wat voor soort werk past er bij je, wat voor soort rol past er bij je, wat voor werkomgeving, wat voor werksfeer, wat voor management style? Middels sollicitatietrainingen, middels kennismakingen met bedrijven en speeddates met deskundigen uit het werkveld kom je daarachter. (afgestudeerde economie, Nederlandse achtergrond) 


\section{Box 6.3 Voorbereiding op bedrijvendagen}

Over het actief bij elkaar brengen van studenten en werkgevers via matching of bedrijvendagen zijn alle betrokken partijen enthousiast. Toch zijn er verschillende voorstellen gedaan om de voorbereiding van studenten op deze dagen te verbeteren, om daarmee gelijke kansen te bieden aan alle groepen. Er is namelijk geconstateerd dat de huidige voorbereiding en opzet van dagen het verschil vergroot tussen studenten die meer of minder zeker zijn van zichzelf en hun kansen. De studenten met een migratieachtergrond geven vaker aan ondersteuning te willen bij de voorbereiding op een gesprek.

Bedrijvendagen? Dat werkt alleen als je de goede vragen kan stellen. Ik ben zelf introvert. Als zo'n event er is, vond ik het moeilijk om mijzelf goed te presenteren. Dan vraag je 'wat voor vacatures hebben jullie' en dan verwijzen ze je naar een website. En dan is het gesprek klaar, daar heb je niets aan. Het gaat om het geven van een goede pitch. En dat vraagt om voorbereiding door de opleiding van de netwerk-events, zodat studenten met een migratieachtergrond zich er ook in herkennen. (afgestudeerde bedrijfskunde, Marokkaanse achtergrond)

Ze hadden wel een speeddate maar deze is te kort voordat stage begint en mag dus wel vaker per jaar gehouden worden. Door de speeddate heb ik wel mijn netwerk kunnen opbouwen: ik heb er een goed contact met een notaris aan over gehouden. (afgestudeerd rechten, Koerdisch Portugese achtergrond)

\subsubsection{Presenteren en voor jezelf opkomen}

Alle opleidingen maken in hun curriculum ruimte voor is voor presentatievaardigheden. Studenten en alumni zijn positief over de aandacht hiervoor in het kader van mentoring, LOB-vakken en extra activiteiten gericht op solliciteren. Veel waardering is er ook voor het leren om jezelf online te presenteren. Studenten en afgestudeerden geven aan baat te hebben bij de tips over het aanmaken van een Linkedln-profiel, het gebruik van foto's, de opmaak van een cv etc. De geïnterviewde studenten en afgestudeerden van Rechten en Economie zijn over het algemeen tevreden over de informatie die zij krijgen over de formele kant van werk en solliciteren.

Wel merken verschillende geïnterviewden op dat dit type activiteiten een verplicht onderdeel van de studie moeten zijn, omdat anders de studenten die deze vorm van onderwijs het meest nodig hebben, niet worden bereikt. In deze context is gewezen op een verschil tussen studenten in relatie tot het opleidingsniveau van de ouders. Studenten met laagopgeleide ouders lijken in de praktijk vaker onzeker te zijn over hun eigen presentatie tijdens een gesprek met werkgevers. 
In het belang van de overgang naar werk willen studenten beter worden voorbereid op de sollicitatiegesprekken en de eerste maanden op het werk. Vragen die meerdere studenten hebben genoemd zijn: in hoeverre moet je je aanpassen of voor jezelf opkomen? Wat kan je wel en niet verwachten bij een sollicitatie? Wat wordt er van je verwacht in een team?

We worden vooral op het formele voorbereid, maar niet op het emotionele en de praktijk van werken. Pak je dingen zelf op? Het is echt niet eenvoudig om in een team te werken. Je moet sterk in je schoenen staan, soms kom je een week lang huilend thuis. Daar word je helemaal niet op voorbereid. (student rechten, Frans-Zwitserse achtergrond)

Er worden door de opleiding vacatures op een blackbord geplaatst waar de werkdruk heel hoog is en de vergoeding laag of niet. We zouden moeten leren onderhandelen over arbeidsvoorwaarden. Dat je dat gesprek kan voeren. (studente rechten, Marokkaanse achtergrond)

We hebben een vak gehad: solliciteren. Je moet een CV schrijven, en een gesprek voeren met acties. Dat duurde alles bij elkaar 3 uur. Er zijn zoveel studenten die zoiets nog nooit hebben gedaan. Mijn moeder kan mij niet helpen. Waar solliciteer je wel, waar niet? En moet je wel tevreden zijn met een eerste aanbod? (student rechten, Poolse achtergrond)

Al eerder is benadrukt dat hbo'ers zich onvoldoende voorbereid voelen op de praktijk. Er zou door docenten een reëler beeld geschetst moeten worden van de mogelijke problemen die studenten en afgestudeerden in het werkveld kunnen tegenkomen. Dat er sprake kan zijn van een 'gesloten' bedrijfscultuur, dat sommige bedrijven daardoor moeilijk toegankelijk zijn en dat niet iedere toekomstwens zo maar is te vervullen. Ook ongelijke toegang en vooral 'wat te doen in zo'n geval', is volgens hbo'ers met een migratieachtergrond weinig besproken.

School moet niet een ideaalbeeld creëren dat alles mogelijk is. Ik weet nog wel dat ik een introductiedag had en dat ze zeiden dat er heel veel mogelijkheden zijn, maar niet specifiek waar je kan doorgroeien. Ze begeleiden daarna ook niet waar je kan zoeken en hoe het er echt aan toe gaat. Ze vertellen niets over de grotere bedrijven, the Big Four. Daar kom je echt niet zo snel binnen, dat werd niet verteld. Ja, tenzij je wit bent en je papa daar werkt. (afgestudeerde rechten, Chinese achtergrond)

Je zou meer moeten leren over wat er speelt in de sector, wat is de cultuur van het bedrijf, zoals nuchter ingesteld zijn bijvoorbeeld (student economie, Turkse achtergrond)

Er worden vragen gesteld tijdens sollicitatiegesprekken die irrelevant zijn of niets te maken hebben met de functie. Hoe ga je daarmee om? Het is goed dat de opleiding meer bewustwording creëert welke vragen er absoluut niet gesteld mogen worden aan de sollicitant. (afgestudeerde Recht, Turkse achtergrond) 


\subsection{De onderwijsprofessionals aan het woord}

\subsubsection{Meer persoonlijk contact met studenten}

Niet alleen studenten, ook een deel van de geïnterviewde onderwijsprofessionals denkt dat de kansengelijkheid van hbo'ers gebaat is bij een sterke docent-student binding. Zij signaleren dat een deel van de docenten in de praktijk weinig contact maakt met studenten en zich vooral richt op het overbrengen van vakkennis. Het uitgangspunt dat de hbo-student zelfstandig moet werken, zou deze docenten in zekere zin vrijpleiten van betrokkenheid bij de student. Terwijl juist studenten die zich nog weinig thuis voelen in de hbo-cultuur gemotiveerd worden door persoonlijk contact en docenten die betrokkenheid tonen (zie box 6.4).

Het gaat er om in de klas iemand aan te kijken, namen te onthouden, je laten inroosteren zodat je vaker een zelfde klas tegenkomt, laten zien 'het kan me wat schelen', dat je interesse toont. Het gaat niet om dat uur apart met de student, maar laat eens wat van jezelf zien, ook in de klas. Docenten moeten ook allemaal SLB kunnen, dat kan alleen als je iedereen erin ontwikkelt en dat is niet zo. Voor velen wordt het gewoon een standaardpraatje. Het gaat niet om docenten bashen, die zitten ook klem. Die worden ingeroosterd voor SLB. Alles wordt heel instrumentalistisch opgevat, in activiteiten en niet in betrokkenheid (professional rechten)..

\section{Box 6.4 Belang van contact en hoge verwachtingen}

Juist studenten die nog moeten wennen aan de cultuur van de hbostudie en stagebedrijven zouden zich door gebrek aan herkenning, persoonlijk contact en 'gezien worden' onzekerder gaan voelen. Verschillende onderwijsprofessionals waarschuwen dat met name de eerste generatie studenten (met een migratieachtergrond) en studenten die van het mbo komen hun vertrouwen en motivatie verliezen als zij weinig contact of positieve feedback krijgen.

De crux is dat studenten binnenkomen met heel veel motivatie, ze hebben al gestapeld, maar in de eerste drie, vier maanden is het hier gebeurd. Ze raken onzeker. Het is ze niet duidelijk wat er van hen wordt verwacht. Dan kom je in een bedrijf en moet je samenwerken met mensen die je weinig zeggen. (professional rechten)

Een medewerker van een economische opleiding ziet dat sommige docenten vooral jongeren die van het mbo komen onvoldoende motiveren.

Er zijn docenten die lage verwachtingen hebben van deze jongeren, want ze komen uit de verkeerde buurt of van de verkeerde vooropleiding. Dat voelen jongeren, met als gevolg dat zij zich daarnaar gaan gedragen. 
En zo versterken de docenten onbewust de al bestaande ongelijkheid in de maatschappij, terwijl het uiten van hoge verwachtingen juist bijdraagt aan de motivatie van studenten, merken deze onderwijsprofessionals.

Vakdocenten economie, zijn in eerste plaats bedrijfskundigen, zij vinden het lastig om persoonlijke aandacht te geven. Het is een hoger onderwijsding dat we het over de inhoud hebben, maar we vergeten dat het ook allemaal kinderen van 17/18 jaar zijn.... Ons systeem werkt voor een bepaalde groep: voor blonde meisjes. Een jongen uit Zuid die van het mbo komt gaat de eerste dag achter in de klas zitten en aan hem wordt door de docent niets gevraagd. En omdat er nooit wat gevraagd wordt, gaat hij nooit wat zeggen. Studenten worden geconditioneerd in het beeld waar ze thuishoren. Door gedrag dat om hen heen wordt vertoond. Bijvoorbeeld: een moslimmeisje slaat niet met de vuist op tafel. (professional economie)

\subsubsection{Maatwerk en extra ondersteuning bij studievertraging}

Mannelijke studenten en studenten met een migratieachtergrond lopen om uiteenlopende redenen vaker studievertraging op. Het gaat hierbij om studenten met verschillende achtergronden. Een aantal begeleiders van langstudeerders signaleert dat deze studenten op meerdere fronten buiten de boot vallen. Dat zij langer over hun studie doen, maakt al dat ze het waarschijnlijk lastiger krijgen op de arbeidsmarkt. De activiteiten die worden aangeboden op het gebied van stagevoorbereiding komen voor hen echter op een verkeerd moment. De studenten die het reguliere programma volgen krijgen bijvoorbeeld een half jaar voordat ze op stage gaan een sollicitatietraining, maar voor een student met achterstand komt die training veel te vroeg omdat hij eerst zijn achterstand moet wegwerken voordat hij op stage mag. Daarbij komt dat de oorzaken van de vertraging, zoals geen binding met de opleiding en persoonlijke omstandigheden, ook bijdragen aan minder actief en assertief zoekgedrag.

Tot slot is de impact van studievertraging op het zelfvertrouwen van studenten vaak zeer groot. Meer en gerichtere aandacht en begeleiding voor deze groep zou volgens deze professionals niet alleen bijdragen aan meer studiesucces maar ook aan gelijke kansen op de arbeidsmarkt.

\subsubsection{Verbeteren aansluiting afstudeerstage bij werkveld}

Veel onderwijsprofessionals noemen, net als de studenten, vooral de invulling van de afstudeerstage zeer lastig vanwege de moeizame aansluiting bij het werkveld. De nadruk op het doen van onderzoek in het hbo en dan met name bij de Proeve van Bekwaamheid ter afsluiting van de opleiding, maakt dat vooral deze stage lastiger is in te vullen. Opleidingen krijgen van bedrijven minder aanbod van dergelijke plekken en voor studenten is het lastiger om goed te verwoorden wat de meerwaarde voor 
een bedrijf is van een dergelijke opdracht. Ook bij dit onderdeel ervaren groepen (met een migratieachtergrond) die al om andere redenen moeilijker een stageplaats of werk vinden, hier meer last van.

Verschillende onderwijsprofessionals pleiten voor een heroverweging van de huidige eisen aan de afstudeerstage. Zij vragen in hoeverre een dergelijke stage bijdraagt aan een goede voorbereiding en gelijke kansen op de arbeidsmarkt.

\subsection{De werkgevers aan het woord}

In deze paragraaf beschrijven we welke factoren volgens de werkgevers centraal staan in de overgang van een hbo-studie naar de arbeidsmarkt. Wat zijn volgens hen de knelpunten, wat gaat goed en hoe denken zij dat er gelijke kansen op stage en werk kunnen ontstaan.

\subsubsection{Arbeidsmarktrelevantie van hbo-opleidingen}

Een belangrijk positief punt van hbo-studenten dat een meerderheid van de geïnterviewde werkgevers onderschrijft, zijn de goede communicatieve en commerciële vaardigheden van hbo'ers. Zeker in vergelijking met wetenschappelijk opgeleide studenten (met name in het geval van rechten) zijn hbo-studenten beter in staat om klantcontact te onderhouden en brengen zij meer praktische vaardigheden mee. Dit is dus een kenmerk waarmee hbo-studenten zich kunnen onderscheiden tijdens sollicitaties.

Een specifiek obstakel in de aansluiting tussen opleiding en bedrijven zijn echter de eisen die vanuit de hogescholen aan de (afstudeer)stage worden gesteld. Het gaat daarbij zowel om de inhoudelijke eisen, dus de competenties die studenten moeten opdoen en de leerdoelen die zij moeten behalen, als om de praktische inrichting van de stage. Voor bedrijven kan het lastig zijn om bij de invulling van de stages aan deze eisen te voldoen.

"De periode ligt vast, ze moeten ook nog eens relevant onderzoek kunnen doen en dan moeten ze nogal hun competenties afvinken. Dat sluit soms niet goed aan bij wat je als bedrijf kunt bieden. Het is een beetje jammer, dan moet je je in bochten wringen om alles af te vinken, terwijl het voor de student beter is om gewoon de bedrijfsroutine te volgen. Dus het zou wel beter zijn als de opleiding daar wat meer flexibiliteit in zou kunnen bouwen." (professional in de private sector)

Dit is niet alleen maar een taak voor hogescholen. Grotere werkgevers beseffen goed dat zij ook zelf belang hebben bij een goede inrichting van het stageproces en een nauwe afstemming daarvan met de opleidingen. Het kan voor hen zelf ook van belang zijn om hier goed op aan te sluiten. Dit besef komt vooral bij de respondenten uit de publieke 
sector naar voren. Zij pleiten voor een nauwere samenwerking en een betere structurele oplossing voor de instroom van stagiaires binnen hun organisatie.

"De stage is wel een heel zelfstandige opdracht. Ik denk dat er ook wel meer samenwerking in gevonden kan worden. Dus meer naar een situatie waarin de hogeschool en de gemeente samenwerken om de studenten nog makkelijker op de juiste plek te krijgen. Dat is ook voor ons van belang, om weer jong talent binnen te krijgen. Zij leren toch weer andere dingen op school, dat is ook echt een aanvulling op het team." (professional bij een gemeente)

\subsubsection{Actievere matching vanuit de hogeschool}

Uit de interviews blijkt dat juist de organisaties die actief bezig zijn met het bieden van kansen aan divers talent ook intensiever contact met de hogescholen hebben.

Terwijl bij de werkgevers in de publieke sector deze contacten tot goede resultaten leiden, mede omdat de werkgevers zelf de stap naar de hogeschool zetten, blijkt er in de samenwerking tussen private werkgevers en de hogescholen nog wel wat te winnen. Die contacten zijn er voor een deel al wel, maar worden volgens de werkgevers nog niet voldoende benut. Als dit wel zou gebeuren, kan de hogeschool zelf voor het netwerk van de studenten zorgen, er meer strategisch gebruik van maken en studenten en bedrijven veel beter matchen.

"In de praktijk zie je werkgevers niet actief inzetten op diversiteit...Daarom is het zo belangrijk dat hogescholen hen ook wel een deel van het werk uit handen nemen door echt contact te leggen. Het belangrijkste is dat het contact echt plaatsvindt, dus dat de eerste drempel beslecht wordt. Daarna komt het goed, maar het eerste contact moet gefaciliteerd worden, heel bewust. Er zijn genoeg werkgevers die hier echt wel in mee willen. Maar ze gaan niet heel veel extra investeren, dus je moet wel naar ze toekomen." (professional in de commerciële sector)

Het gaat daarbij over de bemiddeling tussen student en individuele personen binnen een bedrijf: de warme introductie. Vooral bij kleine werkgevers is zo'n persoonlijk introductie effectief. Als een hogeschool haar netwerken van mkb-ers actief inzet, kan volgens de werkgevers snel een match tot stand worden gebracht.

"Wat werkt is dat er een bemiddelaar is. lemand die opbelt en zegt dat hij een student heeft die je aan werk kunt helpen. Dan kan het eigenlijk altijd wel." (professional in de private sector)

Dit kan ook in het belang van bedrijven zelf zijn. Er zijn immers ook bedrijven, zowel groot als klein, die juist moeite hebben om geschikte kandidaten voor stages of banen te vinden. Door een gebrek aan samenwerking tussen bedrijven en hogeschool, blijven zowel voor de werkgever als voor de studenten kansen onbenut. 


\subsubsection{Intensievere sollicitatiebegeleiding en -oefening}

Er is sprake van een discrepantie tussen de verwachtingen van de werkgevers bij sollicitatiegesprekken en de voorbereiding van de studenten. Vooral werkgevers met een Nederlandse achtergrond verwachten een 'actieve' houding van sollicitanten, zoals zelf vragen stellen en initiatief tonen, terwijl we al eerder vaststelden dat die houding door een deel van de studenten met een migratieachtergrond als onbeleefd wordt gezien. Werkgevers trekken de conclusie dat studenten actiever begeleid zouden moeten worden voorafgaand aan en tijdens de sollicitatiefase. Een betere voorbereiding op de schriftelijke sollicitaties (zie vorig hoofdstuk) en op het voeren van het sollicitatiegesprek, draagt volgens werkgevers bij aan gelijkere arbeidsmarktkansen.

"Scholen zeggen: je moet stagelopen, dus zoek het maar uit. Het is goed om daar ook begeleiding te geven. Ook echt op de basale dingen: hoe gaat nou een sollicitatiegesprek? Ik zag bijvoorbeeld bij kandidaten met een Turkse achtergrond dat het er ook om gaat dat je mensen aankijkt en zelf vragen stelt; dat dit niet onbeleefd is, maar dat het juist goed is. Dat je niet moet wachten, dat je zelf met dingen komt. Dat je zelf op Linkedln namen gaat zoeken, dat je zelf mensen gaat benaderen." (professional in de private sector)

Naast de basis van sollicitatievaardigheden geven werkgevers aan dat het belangrijk is voor studenten om expliciet aan te geven wat zij willen doen, bijvoorbeeld in het kader van hun stage, of wat zij een bedrijf te bieden hebben in het geval van een baan. Omdat de meeste bedrijven klaarblijkelijk verwachten dat studenten met een duidelijk verhaal komen en dit ook goed kunnen overbrengen, is het van belang dat studenten in staat worden gesteld om te oefenen met sollicitatie- en werksituaties. De valkuilen die waarschijnlijk mede te maken hebben met de migratieachtergrond (zoals een terughoudende opstelling, of juist een 'overcompensatie') kunnen daarbij expliciet besproken worden (Box 6.5). Zo kunnen hogescholen een 'zachtere landing' van hun studenten op de arbeidsmarkt bevorderen, door goed op de hoogte te zijn van de specifieke kennis die bedrijven zoeken bij sollicitanten.

"Soms heb je heel specifieke kennis nodig. Juist in de technische sector, de specifieke rechtsgebieden die je moet kennen. Als je dat kunt combineren met vaardigheden zoals klantgerichtheid, technische kennis, dan kun je echt van toegevoegde waarde zijn. Maar dan moet dat ook blijken uit je sollicitatie. Je moet heel gericht kunnen solliciteren. Uit een brief moet blijken: als je mij aanneemt, dan kan ik het volgende toevoegen aan je bedrijf. Je moet heel duidelijk zijn in wat je meerwaarde is." (professional in de private sector)

\section{Box 6.5 Andere framing in sollicitatie}

Als onderdeel van de begeleiding en de tips die studenten meekrijgen vanuit de hogeschool, zou volgens werkgevers ook expliciet aandacht besteed kunnen worden aan de manier waarop studenten hun eigen 
achtergrond - cultureel of anderszins - framen en hierover in sollicitaties communiceren. Uit de interviews met werkgevers blijkt dat het, zeker ook in een commerciële omgeving, juist in het voordeel van sollicitanten kan werken dat zij een breed perspectief meebrengen. Zeker als een bedrijf op internationaal niveau opereert, kan ervaring met andere culturen dan de Nederlandse een pré zijn, mits goed gecommuniceerd.

"Mensen met een biculturele achtergrond hebben in principe iets te bieden. Ik zie wel een vrij diverse groep mensen. Veel mensen met een Aziatische achtergrond, Nederlandse Aziaten, ook mensen uit China, maar ook aardig wat mensen uit Turkije, Marokko, Suriname. Of mensen die lang in het buitenland hebben gewoond met hun ouders.... Het is wel prachtig als iemand daadwerkelijk die ervaring heeft, maar het is meer nog een manier van naar de wereld kijken, een soort nieuwsgierigheid, dingen niet raar vinden." (professional in de private sector)

Deze mogelijkheid tot een andere framing in het sollicitatieproces geldt overigens niet alleen voor het hebben van een migratieachtergrond. Als studenten tijdens hun sollicitatie kunnen aangeven dat zij levenservaring hebben opgedaan door hun sociaal-culturele achtergrond of bepaalde levensgebeurtenissen, dan kan dat volgens de geïnterviewde werkgevers juist interessant zijn voor bedrijven.

\subsubsection{Meer arbeidsmarktkennis bij hogescholen}

Werkgevers uiten unaniem de wens dat de hogescholen (meer) op de hoogte zijn van de werkpraktijk, de wijze waarop studenten een meerwaarde voor een bedrijf kunnen vormen en hoe ze kunnen groeien binnen een bedrijf, van functie naar functie.

"Scholen moeten beter weten hoe de werk- en arbeidsmarktpraktijk eruitziet. Dat je soms via een lagere functie binnen moet komen, en dan verder kunt groeien en doorontwikkelen. Juist bij de kleinere bedrijven." (professional in de private sector)

In de gesprekken met de werkgevers komt regelmatig het beeld naar voren dat de opleidingen zich vooral richten op overheidswerkgevers en hun begeleiding van studenten daar vooral bij laten aansluiten.

Werkgevers kunnen er zelf ook voor zorgen dat de aansluiting met de opleiding verbetert en dat er meer kansengelijkheid ontstaat. Er zijn positieve ervaringen opgedaan met het veranderen van de sollicitatieprocedure: minder op basis van brievenselectie en meer via persoonlijke kennismaking en/of nieuwe manieren om competenties van sollicitanten te meten. Eén van de geïnterviewde werkgevers werkt gericht aan waardevrije selectie en heeft daar positieve ervaringen mee. Daarbij wordt gebruik gemaakt van een assessment game waarbij het persoonlijke profiel van de sollicitanten als totaalsom van drie verschillende computerspellen wordt bepaald. In de ontwikkeling van de game is 
rekening gehouden met culturele bias, het is dan ook expliciet gericht op een neutrale beoordeling.

"Je haalt het profiel eruit door het spel te spelen; dat bepaalt hoe jij je werk doet... Er zit geen goed of fout, maar het gaat om een bepaald profiel. Situaties gekoppeld aan kwaliteiten.... Het mooie daarvan is dat je scores ziet, je ziet nog niets over werkervaring, opleiding etc. We boeken hiermee mooie resultaten." (professional bij een gemeente)

Naast dit soort aanpassingen van het wervingsproces menen werkgevers dat het in belang is van kansengelijkheid wanneer zijzelf meer outreachend te werk te gaan en studenten of starters uitnodigen voor matchingsprogramma's, kennismakingsdagen of andere projecten.

\subsection{Samenvatting}

In In dit hoofdstuk staat beschreven wat er volgens hbo'ers, onderwijsprofessionals en werkgevers nodig is voor een goede overgang naar stage en werk, en wat er specifiek in het belang is voor gelijke kansen van hbo'ers met en zonder een migratieachtergrond.

Studenten en afgestudeerden zijn positief over hun opleiding wanneer zij persoonlijk contact hebben met onderwijsprofessionals en zich gesteund hebben gevoeld bij het vinden van stages. Wanneer opleidingen investeren in (de voorbereiding van) de ontmoeting tussen studenten en werkgevers (via bedrijvendagen, bijhouden van vacatures, introductie van studenten bij bedrijven) ontstaan er volgens hbo'ers betere en gelijkere kansen op stage en werk.

Het vertrouwen in gelijke kansen neemt ook toe wanneer studenten zich kunnen herkennen in professionals in onderwijs- en werkveld. Hbo'ers met een migratiegrond pleiten daarom voor 'rolmodellen' bij de docententeams, maar ook bijvoorbeeld tijdens bedrijvendagen.

Een deel van de geïnterviewde onderwijsprofessionals ziet - net als de hbo'ers - dat de kansen op stage en werk mede afhankelijk zijn van de contacten tussen docenten en studenten. Een beter contact leidt ertoe dat de student met meer vertrouwen het werkveld ingaat en gemakkelijker aanklopt bij eventuele problemen. Dit laatste doen studenten met een migratieachtergrond vaker (te) laat. Verder verwachten onderwijsprofessionals veel van de samenwerking met opleidingen en pleit een deel van hen voor flexibelere regels voor afstudeerstages en langstudeerders. Deze groep heeft lagere kansen op de arbeidsmarkt en kent naar verhouding veel studenten met een migratieachtergrond.

Hbo'ers met een migratieachtergrond geven vrijwel unaniem aan behoefte te hebben aan (betere) voorbereiding op het sollicitatiegesprek en de stagevoorwaarden. Genoemd 
zijn: leren voor jezelf opkomen, onderhandelen over voorwaarden en reageren op discriminerende opmerkingen. Ook de geïnterviewde werkgevers noemen het sollicitatiegesprek een aandachtspunt, hoewel vanuit een ander perspectief. Werkgevers met een Nederlandse achtergrond verwachten dat sollicitanten vragen stellen en initiatief tonen tijdens het gesprek, terwijl een deel van de hbo'ers (met een migratieachtergrond) zich volgens de werkgevers 'te bescheiden' opstelt.

De meeste werkgevers zoeken de oplossing bij de opleidingen en studenten die meer zouden moeten investeren in de voorbereiding op de gesprekken met werkgevers. Verschillende werkgevers merken op dat er aan werkgeverszijde ook wel wat te verbeteren valt aan de cultuursensitiviteit en de inschatting van de competenties van sollicitanten. $^{18}$ Dit laatste kan bijvoorbeeld vergemakkelijkt worden door gebruik te maken van nieuwe (digitale) selectiemethoden.

Professionals in het werkveld zijn positief over een intensieve samenwerking met de hogescholen rond stages en over de opleidingen die goed op de hoogte zijn van de werkpraktijk. Verschillende werkgevers hebben inmiddels positieve ervaringen met 'de warme introductie' en bedrijvendagen. Men verwacht dat beide activiteiten extra relevantie hebben voor studenten met een migratieachtergrond..

18 Ander onderzoek laat zien dat werkgevers met een migratieachtergrond - vanwege hun bekendheid met gedragingen en leef- en denkwereld van sollicitanten met een migratieachtergrond - minder moeite hebben om de competenties van deze sollicitanten in te schatten (De Jong, Nijhoff, Wilbrink, Sjoer, \& De Vries, 2018). 
Deel C: Conclusie en Aanbevelingen 



\section{Conclusies en Aanbevelingen}

Met dit onderzoek is - samen met studenten, afgestudeerden, onderwijsprofessionals en werkgevers - gezocht naar verklaringen en oplossingen voor het verschil in kans op stage en werk van hbo'ers met en zonder migratieachtergrond. Dit hebben we gedaan aan de hand van de volgende onderzoeksvraag:

Welke factoren tijdens en kort na de studietijd in het hoger beroepsonderwijs zijn van invloed op het verschil in kans op werk na afronding van de studie tussen jongeren met een migratieachtergrond en jongeren zonder migratieachtergrond?

We starten dit afsluitende hoofdstuk met een samenvatting van de belangrijkste bevindingen (paragraaf 7.1). Op basis van de uitkomsten van het onderzoek doen we vervolgens aanbevelingen die kansrijk zijn bij het bevorderen van gelijke toegang tot de arbeidsmarkt (paragraaf 7.2)

Voorafgaand aan de conclusies en aanbevelingen geven we graag nog een toelichting. We zijn het onderzoek gestart met een vragenlijst die door bijna 8000 afgestudeerden bij hbo-opleidingen is ingevuld. Vervolgens zijn er verdiepende interviews (75) gehouden. De interviews hebben plaatsgevonden in de context van twee opleidingsrichtingen, te weten Economie en Rechten. Wij verwachten dat dit rapport eveneens relevant is voor andere opleidingsrichtingen, ondanks het gegeven dat iedere opleiding(srichting) een eigen context kent. Het feit dat de arbeidsmarktkansen per opleidingsrichting en regio uiteenlopen, laat onverlet dat het vraagstuk van gelijke kansen op stage en werk het gehele hoger onderwijs treft.

De onderzoeksvraag brengt met zich mee dat veel van de gevonden knelpunten en oplossingsrichtingen in het onderwijsveld liggen. Het bevorderen van gelijke kansen vraagt echter om inspanningen van alle betrokken partijen, te weten hbo'ers, opleidingen en werkgevers. Voor studenten en afgestudeerden biedt het rapport hopelijk (h)erkenning, maar ook inzichten in de mogelijkheden om zelf hun kansen te vergroten. Werkgevers kunnen op hun beurt in dit rapport lezen over de ervaringen van hbo'ers met het zoeken van stage en werk.

Met de hbo'ers is zowel gesproken over hun positieve ervaringen met de studie, stage en werk, als over ervaringen met ongelijke behandeling of discriminatie. Wij danken alle respondenten voor hun tijd en vertrouwen. $\mathrm{Zij}$ hebben ons geholpen om beter zicht te krijgen op het brede spectrum van factoren dat bepalend is voor (gelijke) toegang tot stage en werk. Discriminatie op de stage- en arbeidsmarkt is een van de factoren, blijkt 
uit het kwalitatieve deel van dit onderzoek. Voor een 'harde' meting van de mate waarin hbo'ers te maken krijgen met discriminatie is echter ander aanvullend onderzoek nodig.

\subsection{Conclusies}

In het kwantitatieve deel van het onderzoek is een brede set individuele factoren bekeken, in relatie tot de arbeidsmarktpositie van hbo-afgestudeerden. De analyses van zowel stages tijdens de opleiding alsmede de eerste baan na het afstuderen laten zien dat het nadeel dat jongeren met een niet-westerse en jongeren met westerse migratieachtegrond ervaren vooral zichtbaar is tijdens de pre-entry fase. Met andere woorden, jongeren met een migratieachtergrond meer moeite hebben om een stageplek te vinden en meer moeite hebben om na het afstuderen werk te vinden. Dit nadeel vertaalt zich niet per se in een kwalitatief matigere eerste baan na afstuderen.

De kans op het vinden van werk na het afstuderen wordt door een aantal algemene factoren bepaald, te weten de algemene economische situatie, de gekozen studie en de werkervaring tijdens de studie. Met name studiegerelateerde werkervaring tijdens de studie en een hoge score op de psychologische constructen 'self-efficacy' en 'drive' verhogen de kans op het vinden van werk na het afstuderen.

Uit de vragenlijst komt naar voren dat jongeren met een niet-westerse migratieachtergrond: (a) relatief vaker een studie kiezen met matigere algemene arbeidsmarktperspectieven; (b) minder vaak werkervaring hebben die herkenbaar is voor werkgevers en (c) een lagere score hebben op self-efficacy. Jongeren met een westerse migratieachtergrond en jongeren zonder migratieachtergrond kiezen gemiddeld vaker voor opleidingen met betere arbeidsmarktperspectieven en scoren gemiddeld hoger op selfefficacy dan jongeren met een niet-westerse achtergrond.

De analyses laten daarnaast zien dat de meeste individuele factoren (zoals leeftijd, opleiding ouders) niet of nauwelijks verband houden met de geconstateerde verschillen in toegang tot de arbeidsmarkt van hbo'ers met en zonder migratieachtergrond. Dat discriminatie wel van invloed is op de arbeidsmarktkansen is hierboven al genoemd.

\section{Niet je netwerk, maar hoe je netwerkt}

Uit de interviews maken we op dat veel hbo-studenten en onderwijsprofessionals menen dat ongelijke arbeidsmarktkansen mede een gevolg zijn van de netwerken waarover de groepen zouden beschikken. Een breed gedeelde aanname is dat studenten zonder migratieachtergrond in de directe omgeving (familie, vrienden) betere netwerken hebben, waardoor zij eerder toegang krijgen tot stage en werk. Dit onderzoek laat zien dat deze veronderstelling waarschijnlijk niet klopt. Allereerst hebben de meeste hbo-studenten - met en zonder migratieachtergrond - geen netwerk in het beroepenveld van de opleidingsrichtingen uit dit onderzoek. Ten tweede lijken de werkgevers bij de werving van hbo-afgestudeerden van deze opleidingen nauwelijks 'via via' aan 
stagiaires of nieuwe werknemers te komen. Het uitzetten van vacatures, traineeships, (online) recruiting en bezoeken van werkgeversdagen zijn manieren waarop werkgevers in contact komen met hbo'ers.

Het netwerk dat de hbo'ers zelf actief opbouwen - via werkervaring, traineeships en online-profilering (bijvoorbeeld profiel op Linkedln) - is van invloed op de kans om in beeld te komen bij werkgevers en recruiters. Alles bij elkaar genomen is 'hoe de hbo'er netwerkt' bepalender voor arbeidsmarktkansen, dan het netwerk dat de hbo'er via thuis of de eigen omgeving 'meekrijgt'. Degenen die zich (online) bescheiden presenteren en bescheiden netwerken ondervinden daar nadeel van doordat zij moeilijker in contact komen met werkgevers. Dit lijkt onder meer te gelden voor (vrouwelijke) hbo'ers die vanuit hun cultuur hebben geleerd om zich bescheiden te presenteren.

\section{Werkervaring en financiële positie van hbo'ers}

Hbo'ers met een migratieachtergrond hebben naar verhouding vaker een bijbaan of een startersbaan buiten de sector waarvoor zij worden/zijn opgeleid. Dit type werkervaring draagt (te) weinig bij aan factoren die de arbeidsmarktkansen positief beïnvloeden zoals het $\mathrm{cv}$, de 'vertrouwdheid' ${ }^{19}$ met de sector en de mogelijkheid om binnen de sector door te stromen of (intern) te netwerken. Een bijbaan en een startersbaan kunnen ook op de lange termijn effect hebben op de arbeidsmarktpositie, omdat het salaris mede wordt bepaald aan de hand van eerder opgedane werkervaring.

Een deel van de hbo-studenten met migratieachtergrond komt voor stages terecht bij bedrijven uit het eigen netwerk. Dit kan leiden tot ongelijke kansen omdat werkgevers bij selectie kijken naar ervaring bij 'herkenbare' bedrijven en/of goede competenties van de sollicitant.

Studenten die vanwege hun (financiële) thuissituatie naast de studie werken, laten zich bij hun keuze voor een stage sterk leiden door de hoogte van de vergoeding. Deze keuze leidt vaak niet tot stagebedrijven die een goede stagebegeleiding bieden.

\section{Selectieprocedure werkgevers}

Veel geïnterviewde hbo'ers met een migratieachtergrond vermoeden zelf (wel eens) gediscrimineerd te zijn bij de beoordeling van de sollicitatiebrief. Signalen zijn het grote aantal afwijzingen, niet beantwoorde sollicitatiebrieven en afwijzingen voor vacatures waarvoor medestudenten zonder migratieachtergrond wel zijn uitgenodigd. Zes van de 31 geïnterviewde hbo'ers met een migratieachtergrond hebben ervaringen met expliciete discriminatie tijdens sollicitatiegesprekken, waarvan vier vanwege het dragen van een hoofddoek. Slechts een zeer klein deel van de studenten met ervaringen of vermoedens van discriminatie meldt dit bij de opleiding, omdat zij verwachten dat de opleiding weinig kan of zal doen.

19 Bijvoorbeeld minder kennis van de ongeschreven regels op de werkvloer en de cultuur van een organisatie. 
De interviews laten wel zien dat werkgevers signalen van discriminatie herkennen bij bedrijven in de eigen sector, maar niet binnen de eigen organisatie. Werkgevers zijn over het algemeen positief over de vakkennis van hbo'ers. Zij zien geen verschillen tussen hbo'ers met en zonder migratieachtergrond als het gaat om vakkennis. Taalvaardigheid van hbo'ers wordt minder positief beoordeeld, maar wordt door werkgevers niet gekoppeld aan de achtergrond van de sollicitant. Gevraagd naar de verklaring voor het verschil in toegang tot de arbeidsmarkt noemen de geïnterviewde werkgevers vooral verschillen in manieren van presenteren en solliciteren.

Werkgevers geven aan dat 'open sollicitaties of gestandaardiseerde reacties op vacatures' in het algemeen weinig kans maken op een uitnodiging voor een sollicitatiegesprek en dat zij juist van kandidaten met een migratieachtergrond veel open of ongerichte sollicitaties ontvangen. Werkgevers met een Nederlandse achtergrond hebben een voorkeur voor sollicitanten die tijdens de gesprekken actief zijn en vragen stellen. Dit past niet altijd bij de hbo'ers met een migratieachtergrond die vaker bescheidenheid vanuit hun cultuur meekrijgen.

De werkgevers die op reguliere basis samenwerken met een hogeschool rond stages zijn daar positief over. Verschillende werkgevers hebben inmiddels positieve ervaringen met 'de warme introductie' van studenten door hoge scholen en met speed-dates en bedrijvendagen. Men verwacht dat deze ontmoetingen leiden tot een gelijkere toegang van de verschillende groepen.

\section{De rolvan het hbo}

De interviews tonen over de hele linie een sterke relatie tussen de tevredenheid van studenten over hun studie en het contact met docenten en andere onderwijsprofessionals. Hoe positiever zij het contact ervaren, hoe gemotiveerder de studenten zijn en hoe eerder zij geneigd zijn om hulp te vragen wanneer zij vastlopen. Deze constatering werkt door op de gelijke kansen op stage en werk. Ondanks de grote inzet van veel onderwijsprofessionals bieden de hbo-instellingen op het onderdeel 'voorbereiding op stage en werk' onvoldoende garanties voor gelijke kansen, hoewel de ene opleiding daar wel beter in lijkt te slagen dan de andere. Veel genoemde basisvoorwaarden voor een succesvolle toegang tot werk zijn: a) voldoende uren binnen het curriculum voor een gedegen voorbereiding op solliciteren; b) voldoende ruimte voor docent-student contact en c) voldoende aandacht voor het (oefenen) met het contact leggen met werkgevers.

Bieden de opleidingen de bovengenoemde voorwaarden niet of beperkt, dan werkt dit met name nadelig door op de arbeidsmarktkansen van studenten en afgestudeerden met een migratieachtergrond. De studenten met een migratieachtergrond vragen in de praktijk minder snel hulp, waardoor problemen met het vinden van stage, te laat starten of slechte kwaliteit van begeleiding en/of ongelijke behandeling door stageaanbieders te lang buiten het zicht van de opleiding kunnen blijven. Dat wordt nog eens versterkt doordat de uren voor stagecoördinatie en -begeleiding bij verschillende oplei- 
dingen onvoldoende zijn om zicht te hebben op de kwaliteit van de stageplekken en op de mogelijke discriminatie door de aanbieders van stageplekken. Wat niet helpt bij het signaleren en reageren op signalen van discriminatie is dat onderwijsprofessionals geen gedeeld beeld hebben van de problematiek. Op verschillende opleidingen die wij voor dit onderzoek bezochten was geen duidelijke visie of missie op het terrein van (on) gelijke kansen en discriminatie.

\subsection{Aanbevelingen gericht op bevorderen (gelijke) kansen}

Op basis van de uitkomsten van dit onderzoek hebben we aanbevelingen geformuleerd, die kansrijk zijn bij het bevorderen van gelijke toegang tot de arbeidsmarkt van hbo'ers met en zonder migratieachtergrond. We sluiten af met een aantal algemene aanbevelingen gericht op de overgang naar stage en werk. In de lijn met ons onderzoeksdoel om hbo-instellingen te ondersteunen, zijn de meeste aanbevelingen geadresseerd aan het hbo. Zoals eerder genoemd maakt dit de inspanningen van studenten en werkgevers op dit terrein niet minder belangrijk.

De onderzoeksuitkomsten wijzen op het nut en de noodzaak om met elkaar het gesprek aan te gaan over wat hbo-instellingen kunnen doen om discriminatie en ongelijke kansen op de arbeidsmarkt aan te pakken, zowel qua bewustwording, ondersteuning als het aanpassen van werkprocessen. Hieronder doen wij aanbevelingen die het gesprek hierover en de noodzakelijke vervolgstappen kunnen ondersteunen.

\section{Aanpak, kennis en gesprek over discriminatie}

Om adequaat te kunnen reageren op (signalen van) discriminatie hebben de onderwijsprofessionals duidelijkheid nodig over de handelingsperspectieven die zij kunnen en/of moeten inzetten. Terwijl sommige hbo-instellingen uit dit onderzoek daar al veel ervaring mee hebben, is dat zeker nog niet bij alle hbo-instellingen het geval. De hbo-instellingen zouden onderling kennis kunnen delen en meer gebruik kunnen maken van de inzichten die vanuit o.a. onderzoek, kennisinstituten en antidiscriminatie-voorzieningen beschikbaar zijn.

Een eerste praktische stap is het opstellen van een protocol of richtlijnen, die professionals kunnen volgen wanneer zij een melding of signalen ontvangen van studenten over discriminatie door stage aanbieders. Een gedegen aanpak van het vraagstuk vraagt echter om meer dan het opstellen van richtlijnen. Kennis en bewustwording van het vraagstuk discriminatie en de impact die het heeft op de slachtoffers zijn nodig om adequaat te kunnen reageren. Nu spreken professionals met overtuiging over de noodzaak van inclusie, zonder zicht te hebben op de mate waarin discriminatie de studenten en collega's met een migratieachtergrond treft. Het is daarom van belang dat over de problemen die studenten ervaren met stage-aanbieders wordt gesproken binnen de teams en dat deze problemen op opleidingsniveau worden gemonitord. Onderwijsprofessionals, zeker degenen die contact hebben met studenten over hun 
stages, dienen kennis te hebben over de eisen die stage-aanbieders wel/niet mogen stellen aan stagiaires. Dat vraagt om deskundigheidsbevordering in het hbo van wet- en regelgeving ten aanzien van discriminatie.

Voor studenten is het van belang te weten dat de opleiding signalen van discriminatie serieus neemt, dat zij kunnen rekenen op ondersteuning wanneer zij discriminatie ervaren en dat zij weten of er vertrouwenspersonen zijn bij wie zij terecht kunnen. De meldingsbereidheid van studenten neemt toe als opleidingen een duidelijke visie uitdragen gericht op het tegengaan discriminatie op alle gronden.

\section{Biedt studenten handvatten bij moeilijke gesprekken}

Sollicitatiegesprekken kunnen onprettig verlopen: slechte voorwaarden, oneigenlijke eisen, discriminerende vragen. Studenten die het overkomt, weten vaak niet hoe zij zich kunnen verweren. Zij missen kennis over hun juridische positie en handvatten om het gesprek hierover aan te gaan. Opleidingen kunnen studenten tijdens de voorbereidende lessen meer handelingsperspectieven bieden op moeilijke of discriminerende sollicitatiegesprekken. Daarbij moet duidelijk zijn dat studenten altijd kunnen terugvallen op de opleiding voor bemiddeling en/of melding van discriminatie als dit nodig is. Het empoweren van studenten komt niet in de plaats van de verantwoordelijkheden van de opleidingen om in gesprek te gaan met, dan wel op te treden tegen discriminerende stage aanbieders.

\section{Meer aandacht voor de individuele student}

Studenten met een migratieachtergrond en studenten met (financiele) zorgtaken voor familie hebben, vergeleken met andere studenten, meer behoefte aan docentcontact en hulp bij het vinden van stages. Verschillende studies (Erberder et al., 2015, De Jong et al. 2017, Tinto 2017) tonen aan dat de kans op studiesucces toeneemt wanneer studenten ervaren dat zij positief contact hebben met docenten, zich gekend voelen en ervaren dat docenten hoge verwachtingen van hen hebben. Actieve en persoonsgerichte studiebegeleiding is een cruciale voorwaarde voor studiesucces (Inspectie van Onderwijs, 2019) en voor de arbeidsmarktkansen van studenten. De verwachting is dat studenten zich hierdoor meer verbonden voelen met de opleiding en het eerder melden als zij vastlopen in studie, stage en/of thuissituatie. Het gaat hierbij enerzijds om meer tijd, maar ook om wat je met die tijd doet: de begeleidingsvaardigheden van docenten, het tonen interesse en begrip en het nemen van verantwoordelijkheid voor het (studie) succes van je studenten.

\section{Betere advisering over toegang krijgen tot de arbeidsmarkt}

De toegang tot de arbeidsmarkt wordt in belangrijke mate bepaald door de werkervaring en daarmee samenhangend het netwerk, dat de hbo'er opbouwt voor en tijdens de studie. Afgestudeerden die ervaring hebben opgedaan in het werkveld waarvoor zij worden opgeleid, hebben een sterker cv, meer ervaring met de 'ongeschreven regels' en daarmee een betere uitgangspositie. Opleidingen kunnen hierbij ondersteunen door meer informatie te geven over de kansrijke keuzes van stage, bijbanen en startersbanen. 
Ook is het raadzaam dat hbo-opleidingen voorzichtig zijn met het advies aan studenten om open sollicitaties te sturen naar bedrijven die hen interesseren. De kans op een positieve reactie op een open sollicitatie is klein en bovendien in het voordeel van de sollicitanten die 'herkenbaar' zijn voor de werkgever. Beter is het om gerichte sollicitatiebrief te versturen, met een zeer duidelijke koppeling naar de functie-eisen. Ook online netwerken, intern netwerken (vanuit stage, bijbaan of startersbaan) of self branding verhogen de kansen om in beeld te komen bij werkgevers.

De opleidingen zouden studenten structureel kunnen wijzen op het nut van traineeof startersprogramma's. ${ }^{20}$ Dat betekent dat opleidingen moeten beschikken over een relevant netwerk, wat nog niet het geval is bij alle opleidingen. Trainees versterken hun arbeidsmarktpositie, want zijn de hbo'ers eenmaal binnen dan is het veel eenvoudiger geworden intern door te stromen en te netwerken.

\section{Voorbereiding op contact met bedrijven}

Door ontmoetingen te organiseren tussen studenten en werkgevers (onder andere via speed dates, bedrijvendagen, gastlessen en sollicitatietrainingen van werkgevers) ondersteunen de opleidingen de arbeidsmarktkansen van hun studenten. Voorwaarde is dat deze activiteiten niet facultatief zijn en plaatsvinden binnen lestijd. Op dit moment doen studenten met (financiële) zorgtaken nog weinig mee aan buiten-curriculaire activiteiten (vanwege bijbanen), terwijl zij er juist baat bij kunnen hebben om hun netwerk te vergroten met werkgevers in de sector waarvoor zij worden opgeleid.

De speeddates en bedrijvendagen bieden gelijke kansen aan studenten uit alle groepen, mits de studenten voorafgaand aan de bijeenkomst voorbereid zijn op het gesprek met de werkgevers (eigen presentatie, open vragen stellen etc.). Gebeurt dit niet dan hebben de studenten die zich makkelijk en 'open' presenteren een grotere kans op een stage-aanbod. Dit is in het nadeel van onzekere studenten en/of studenten die geleerd hebben om zich zeer bescheiden op te stellen.

\section{Zelfstandigheid en matching?}

Van hbo'ers wordt verwacht dat zij zelfstandig zoeken naar stages. Over wat onder zelfstandigheid mag worden verstaan en waar het mogelijk staat voor 'alles zelf uitzoeken' wordt onderling weinig gesproken. Door zowel hoge werkdruk als verschillende meningen binnen teams, lijkt dit gesprek nog weinig op gang te komen. Een heroverweging van de mogelijkheid van matching is zinvol. In (delen van het) het mbo en wo vindt matching wel plaats en wordt het zelfs als noodzakelijk gezien om de kwaliteit van de opleiding te borgen. Het is waardevol om te onderzoeken welke best practices uit het mbo en het wo toepasbaar en overdraagbaar kunnen zijn.

\section{Inzet van rolmodellen en afgestudeerden}

Hbo'ers met een migratieachtergrond uit dit onderzoek scoren lager op het vertrouwen in eigen kunnen bij taken (self-efficacy). Studenten met een lage self-efficacy zijn kwets-

20 Een deel van de opleidingen doet dit al, maar vaak nog niet structureel. 
baarder als het gaat om het succesvol doorlopen van de studie (Erberber et al., 2015, Tinto 2017). Er zijn positieve effecten te verwachten van de inzet van rolmodellen, als onderdeel van een breed pakket aan maatregelen gericht op het versterken van selfefficacy. Studenten met een migratieachtergrond hebben baat bij contact met rolmodellen, bijvoorbeeld via diversiteit onder docenten en medewerkers en het uitnodigen van gastsprekers uit het werkveld met een migratieachtergrond. Ten slotte hebben verschillende opleidingen positieve ervaringen opgedaan met ouderejaars studenten die optreden als mentoren voor jongerejaars.

\section{Dubbelcheck op taalfouten in brieven}

Dit is een open deur, maar daarom niet minder waar. Taalfouten in sollicitatiebrieven staan wat betreft werkgevers in de sectoren van ons onderzoek absoluut op nummer 1 als reden voor een afwijzing. Alle brieven zouden gecheckt moeten zijn. Dat betekent dat er voldoende uren nodig zijn voor de begeleiding en voor een taalaanbod voor wie dat nodig heeft. Tegelijkertijd is het opvallend dat geen enkele opleiding duidelijk zicht op heeft op het taalniveau van de studenten met en zonder migratieachtergrond en de mogelijke verschillen daartussen. Interne analyses lijken nodig om meer grip te krijgen op de vraag in welke mate de factor taal mede verklarend is voor verschillen in studie- en arbeidsmarktsucces.

\section{Voorkomen van langstuderen, draagt bij aan gelijkere kansen}

Studenten met een migratieachtergrond vallen relatief vaker uit, wisselen vaker van studie en zijn oververtegenwoordigd onder de groep langstudeerders. Langer studeren leidt vaak tot slechtere kansen op de arbeidsmarkt. Opleidingen die slecht scoren op studiesucces dragen alleen daardoor al bij aan het vergroten van de ongelijkheid van kansen op de arbeidsmarkt. Om deze reden menen wij dat de maatregelen die gericht zijn op tegengaan van uitval en vertraging, onderdeel vormen van het geheel aan maatregelen gericht op het versterken van gelijke kansen op stage en werk.

\section{Invulling van de afstudeerstage}

De aansluiting tussen de eisen aan de afstudeerstage en de vraag in het werkveld kan beter, menen met name geinterviewden uit het juridische werkveld. Terwijl de studenten de opleiding af moeten sluiten met onderzoek en een Proeve van Bekwaamheid, zijn er weinig werkgevers die stagiaires vragen voor dit type werk. Gegeven dit feit kan de vraag worden gesteld in hoeverre een dergelijke stage bijdraagt aan een goede voorbereiding en gelijke kansen op de arbeidsmarkt. Mogelijk wordt juist hier een kans gemist om na het behalen van het diploma bij het 'bedrijf' te blijven werken. De opleidingen zouden het gesprek hierover intern en met het werkveld kunnen aangaan. 


\section{Bibliografie}

Bandura, A. (1997). Self-efficacy: The exercise of control. W H Freeman/Times Books/ Henry Holt \& Co.

De Jong, M., Logger, J., Peschar, O., Slijper, J.Walraven,G. (2017). Onderzoek beeldvorming, diversiteit en studiesucces opleidingen Business Studies en Social Work.

De Jong, M. Nijhoff, K., Wilbrink, D., Sjoer, E. \& De Vries, S. (2018), Syrische vluchtelingen aan het werk: vragen en antwoorden uit de praktijk, Lectoraat Sociale Innovatie Windesheim, Zwolle.

Erberber , E., Stephens, M., Mamedova, S., Ferguson, S., \& Kroeger, T. (2015). Socioeconomically Disadvantaged Students Who Are Academically Successful: Examining Academic Resilience Cross-Nationally. Policy Brief No.

Inspectie van Onderwijs (2019) Staat van het Onderwijs, Pag 80.

Kappe, R. \& De Jong, M. (2018). Gelijke kansen op stage en werk voor alle hoogopgeleide jongeren. Haarlem: Hogeschool Inholland.

KIS. (2016). Mbo en de stagemarkt, wat is de rol van discriminatie? Utrecht: Kennisplatform Integratie \& Samenleving.

ROA. (2016). Schoolverlaters tussen onderwijs en arbeidsmarkt 2015. Maastricht: ROA.

SCP. (2007). Discriminatiemonitor niet-westerse allochtonen op de arbeidsmarkt 2007. Den Haag: SCP.

SCP. (2010). Discriminatiemonitor niet-westerse allochtonen op de arbeidsmarkt 2010. Den Haag: SCP.

SCP. (2014). Jaarrapport integratie 2013. Participatie van migranten op de arbeidsmarkt. Den Haag: SCP.

SCP. (2016). Integratie in zicht? De integratie van migranten in Nederland op acht terreinen nader bekeken. Den Haag: SCP.

Thijssen, L., Coenders, M., \& Lancee, B. (2019). Etnische discriminatie op de Nederlandse arbeidsmarkt. Mens en maatschappij, 94(2), 141-176.

Tinto, V. (2017) Reflections on student persistence." Student Success, vol. 8, no. 2. 



\section{Bijlages}

\section{Bijlage 1: Kans op deelname aan vervolgonderzoek}

\section{Tabel B.1}

Kans op deelname aan vervolgonderzoek

\begin{tabular}{|c|c|c|}
\hline & Odd's ratio & Sig. \\
\hline Zonder migratieachtergrond & Referentie & \\
\hline Westerse migratieachtergrond & 0.982 & 0.781 \\
\hline Niet-westerse migratieachtergrond & 0.707 & 0.000 \\
\hline Meting 2014 & Referentie & \\
\hline Meting 2015 & 1.129 & 0.001 \\
\hline Meting 2016 & 1.162 & 0.000 \\
\hline Meting 2017 & 1.308 & 0.000 \\
\hline Regio West & Referentie & \\
\hline Regio Noord & 1.110 & 0.027 \\
\hline Regio 0ost & 1.038 & 0.258 \\
\hline Regio Zuid & 0.966 & 0.298 \\
\hline Buitenland & 1.610 & 0.000 \\
\hline Man & Referentie & \\
\hline Vrouw & 1.121 & 0.000 \\
\hline Leeftijd & 1.010 & 0.032 \\
\hline Opleidingssector: economie & Referentie & \\
\hline Opleidingssector: landbouw & 1,249 & ,001 \\
\hline Opleidingssector: techniek & 1,244 &, 000 \\
\hline Opleidingssector: gezondheidszorg & 1,168 &, 000 \\
\hline Opleidingssector: gedrag \& maatschappij & 1,330 &, 000 \\
\hline Gemiddeld afstudeercijfer & 1,393 &, 000 \\
\hline
\end{tabular}

Bron: HBO-Monitor 2014-2017 


\section{Bijlage 2: Kans op werkloosheid: HBO-monitor en subsample}

\section{Tabel B.2}

Kans op werkloosheid: HBO-Monitor en sub-sample (odds ratio's)

\begin{tabular}{|c|c|c|}
\hline & HBO-Monitor & Sub-sample \\
\hline Zonder migratieachtergrond & Referentie & \\
\hline Westerse migratieachtergrond & $1,374^{* * *}$ & 1,349 \\
\hline Niet-westerse migratieachtergrond & $2,323^{* * *}$ & $1,966^{* * *}$ \\
\hline Meting 2014 & Referentie & Referentie \\
\hline Meting 2015 & $0,762^{* * *}$ & $0,745^{*}$ \\
\hline Meting 2016 & $0,670^{* * *}$ & $0,687^{* *}$ \\
\hline Meting 2017 & $0,431^{* * *}$ & $0,319^{* * *}$ \\
\hline Regio West & Referentie & Referentie \\
\hline Regio Noord & $1,324^{* * *}$ & $1,921^{* * *}$ \\
\hline Regio 0ost & $1,210^{* * *}$ & 1,264 \\
\hline Regio Zuid & $1,125^{*}$ & 1,020 \\
\hline Buitenland & $2,028^{* * *}$ & $1,741^{*}$ \\
\hline Man & Referentie & Referentie \\
\hline Vrouw & $1.312^{* * *}$ & $1,359^{* *}$ \\
\hline Leeftijd & $1,072^{* * *}$ & $1,061^{* * *}$ \\
\hline Opleidingssector: economie & Referentie & Referentie \\
\hline Opleidingssector: landbouw & 1,063 & 0,905 \\
\hline Opleidingssector: onderwijs & $0,578^{* * *}$ & 0,739 \\
\hline Opleidingssector: techniek & $0,845^{* *}$ & 0,800 \\
\hline Opleidingssector: gezondheidszorg & $0,442^{* * *}$ & $0,471^{* * *}$ \\
\hline Opleidingssector: gedrag \& maatschappij & $0,875^{* *}$ & 0,796 \\
\hline Gemiddeld afstudeercijfer & $0,887^{* * *}$ & $0,882^{* * *}$ \\
\hline
\end{tabular}

Bron: HBO-Monitor 2014-2017 


\section{Bijlage 3: Empirische modellen}

In de analyses worden het model stapsgewijs opgebouwd om de verklaringen voor het bestaande verschil in de analyse te kunnen onderscheiden.

Model o is het basismodel waarin we slechts een tweetal variabelen opnemen, namelijk een dummy voor de groep respondenten met een westerse migratieachtergrond en een dummy voor de groep respondenten met een niet-westerse migratieachtergrond.

In model 1 tot en met model 4 voegen we stapsgewijs achtergrondkenmerken van de respondent toe aan het basismodel. In model 1 is dit het jaar waarin de HBO-Monitor meting heeft plaatsgevonden, alsmede de regio waarin de respondent op het moment van afname van de HBO-Monitor woonachtig is. In model 2 is dit het geslacht en de leeftijd, in model 3 het opleidingsniveau van de ouders en in model 4 indicatoren over de mate van het gebruik van de Nederlandse taal of andere talen in de communicatie met familie en vrienden.

In model 5 (gevolgde vooropleiding voorafgaand aan hbo-bachelor) en in model 6 (gevolgde opleidingssector en afstudeercijfer in hbo) analyseren we in hoeverre verschillende studiekeuzes en onderwijsloopbanen een verklaring kunnen bieden.

In model 7 tot en met model 11 voegen we onze indicatoren met betrekking tot de gevolgde stages tijdens de hbo-bachelor toe: aantal stages en totale stageduur (model 7), type stage in model 8 (oriëntatie stage, werkervaringsstage, onderzoeksstage), of men zich lid voelde van het stagebedrijf en of men de stage-ervaring goed kon delen tijdens en na de lessen (model 9), de etnische samenstelling van het stagebedrijf (model 10) en tot slot of men van het stagebedrijf een aanbod heeft ontvangen om na het afronden van de bachelor bij het stagebedrijf te komen werken (model 11).

Model 12 tot en met model 16 voegen verdere werkervaringsindicatoren toe. We analyseren of verschillen in werkervaring gerelateerd aan de studie (buiten de stages om) (model 12) verschillen van niet aan studie gerelateerde werkervaring (model 13), verschillen in verschillende types vrijwilligerswerk (model 14), bestuurlijke ervaringen (model 15) en het oprichten van een eigen bedrijf tijdens de studie (model 16) nadere verklaringen kunnen bieden. Ook wordt hier naast het hebben van zo'n ervaring, waar van toepassing, ook de etnische samenstelling van dat bedrijf of de vrijwilligersorganisatie meegenomen.

Model 17 voegt verdere activiteiten toe die aan hogescholen aangeboden kunnen worden zoals algemene informatiebijeenkomsten over de arbeidsmarkt, activiteiten gericht op de sollicitatieprocedure of carrièredagen. Daarnaast wordt ervoor gecontroleerd of men tijdens deze activiteiten in contact is gekomen met bedrijven. 
Model 18 en 19 voegen een aantal verdergaande persoonlijkheidskenmerken toe. In model 18 controleren we voor de bereidheidvan studenten om regionaal, nationaal en internationaal te verhuizen. Via de vragenlijst is daarnaast gemeten in hoeverre respondenten intrinsieke motivatie hebben, extrinsiek gemotiveerd zijn, wat de mate van selfefficacy is, wat hun drive is en in hoeverre ze scoren op zelfstandig werken en samenwerken (model 19).

Tot slot worden in model 20 indicatoren toegevoegd die informatie bieden over de kanalen waarmee na het behalen van het diploma werk gezocht is. 


\section{Bijlage 4: Kans op werkloosheid: vervolgonderzoek}

\section{Tabel B.3}

Kans op werkloosheid: Model 20 (odds ratio's)

\begin{tabular}{|c|c|c|}
\hline & Odd's ratio & Sig. \\
\hline Zonder migratieachtergrond & ref. & \\
\hline Westerse migratieachtergrond & 1,158 & 0,654 \\
\hline Niet-westerse migratieachtergrond & 1,954 & 0,022 \\
\hline Meting 2014 & ref. & \\
\hline Meting 2015 & 0,741 & 0,123 \\
\hline Meting 2016 & 0,750 & 0,124 \\
\hline Meting 2017 & 0,335 & 0,000 \\
\hline Regio West & ref. & \\
\hline Regio Noord & 1,873 & 0,009 \\
\hline Regio 0ost & 1,255 & 0,216 \\
\hline Regio Zuid & 0,932 & 0,729 \\
\hline Buitenland & 1,934 & 0,078 \\
\hline Man & ref. & \\
\hline Vrouw & 1,186 & 0,321 \\
\hline Leeftijd & 1,068 & 0,000 \\
\hline Hebben de ouders een opleiding in het hoger onderwijs gevolgd: nee & ref. & \\
\hline Hebben de ouders een opleiding in het hoger onderwijs gevolgd: ja & 1,318 & 0,096 \\
\hline Opleiding ouders onbekend: ja & 0,076 & 0,080 \\
\hline Taal gesproken met familie - niet alleen Nederlands & 0,853 & 0,558 \\
\hline Taal gesproken met familie - onbekend & 3,149 & 0,402 \\
\hline Taal gesproken met vrienden: niet alleen Nederlands & 1,134 & 0,555 \\
\hline Hoogste vooropleiding is MB0: ja & 0,924 & 0,646 \\
\hline Opleidingssector: economie & ref. & \\
\hline Opleidingssector: landbouw & 0,705 & 0,375 \\
\hline Opleidingssector: onderwijs & 1,267 & 0,408 \\
\hline Opleidingssector: techniek & 0,861 & 0,517 \\
\hline Opleidingssector: gezondheidszorg & 0,622 & 0,088 \\
\hline Opleidingssector: gedrag \& maatschappij & 0,955 & 0,841 \\
\hline Gemiddeld afstudeercijfer & 0,974 & 0,694 \\
\hline Aantal stages gevolgd & 1,109 & 0,325 \\
\hline Aantal uren stages gevolgd & 1,000 & 0,654 \\
\hline Orientatiestage gelopen tijdens laatste twee jaar van HBO-opleiding: Ja & 0,632 & 0,247 \\
\hline Werkervaringsstage gelopen tijdens laatste twee jaar van HBO-opleiding: Ja & 0,884 & 0,556 \\
\hline Onderzoeksstage gelopen tijdens laatste twee jaar van HBO-opleiding: Ja & 0,928 & 0,710 \\
\hline Voelde zich lid van de organisatie waar stage gelopen: Ja & 0,960 & 0,303 \\
\hline Kon ervaringen op stage delen met docenten/mentoren: Ja & 0,953 & 0,197 \\
\hline Organisatie waar stage gelopen: Autochtone omgeving & ref. & \\
\hline Organisatie waar stage gelopen: Autochtone gemengde omgeving & 1,288 & 0,179 \\
\hline
\end{tabular}




\begin{tabular}{|c|c|c|}
\hline Organisatie waar stage gelopen: migranten omgeving & 1,262 & 0,544 \\
\hline Aanbod ontvangen van Stage bedrijf Ja & ref. & \\
\hline Aanbod ontvangen van Stage bedrij: Nee & 1,653 & 0,020 \\
\hline Aanbod ontvangen van Stage bedrijf: Ja, maar afgewezen & 1,228 & 0,407 \\
\hline $\begin{array}{l}\text { Extracurriculaire activiteiten tijdens de laatste twee studiejaren - Betaalde werkervaring } \\
\text { gerelateerd aan studie: Ja }\end{array}$ & 0,636 & 0,027 \\
\hline $\begin{array}{l}\text { Extracurriculaire activiteiten tijdens de laatste twee studiejaren - Betaalde werkervaring } \\
\text { niet-gerelateerd aan studie: Ja }\end{array}$ & 0,611 & 0,011 \\
\hline Vrijwilligerswerk bij Studentenvereniging: Ja & 0,786 & 0,753 \\
\hline Vrijwilligerswerk bij Sportvereniging: Ja & 0,670 & 0,287 \\
\hline Vrijwilligerswerk bij Maatschappelijke organisatie: Ja & 1,637 & 0,097 \\
\hline Organisatie waar vrijwilligerswerk gelopen: autochtone omgeving & 1,135 & 0,681 \\
\hline Organisatie waar vrijwilligerswerk gelopen: gemengde omgeving & 1,127 & 0,777 \\
\hline Organisatie waar vrijwilligerswerk gelopen: migranten omgeving & 0,973 & 0,977 \\
\hline Organisatie waar bestuurservaring opgedaan: autochtone omgeving & 0,750 & 0,296 \\
\hline Organisatie waar bestuurservaring opgedaan: gemengde omgeving & 0,485 & 0,376 \\
\hline Organisatie waar bestuurservaring opgedaan: migranten omgeving & 0,000 & 0,999 \\
\hline $\begin{array}{l}\text { Extracurriculaire activiteiten tijdens de laatste twee studiejaren - Oprichten eigen } \\
\text { bedrijf: Ja }\end{array}$ & 1,036 & 0,921 \\
\hline $\begin{array}{l}\text { Extracurriculaire activiteiten tijdens de laatste twee studiejaren - Geen van } \\
\text { bovenstaande opties: Ja }\end{array}$ & 0,960 & 0,869 \\
\hline Cursussen/Activiteiten tijdens studie - onbekend & 0,675 & 0,304 \\
\hline $\begin{array}{l}\text { Cursussen/Activiteiten tijdens studie - Ja, algemene informatiebijeenkomst(en) over } \\
\text { arbeidsmarkt }\end{array}$ & 0,801 & 0,412 \\
\hline $\begin{array}{l}\text { Cursussen/Activiteiten tijdens studie - Ja, activiteit gericht op sollicitatieprocedure } \\
\text { (schrijven van (V, voeren van sollicitatiegesprek etc.) }\end{array}$ & 1,117 & 0,629 \\
\hline $\begin{array}{l}\text { Cursussen/Activiteiten tijdens studie - Ja, deelname aan carrièredagen / Bezoek van } \\
\text { bedrijven }\end{array}$ & 1,052 & 0,885 \\
\hline $\begin{array}{l}\text { Cursussen/Activiteiten tijdens studie - Ja, activiteiten die u leerde om een eigen bedrijf } \\
\text { op te richten }\end{array}$ & 2,416 & 0,018 \\
\hline $\begin{array}{l}\text { In contact met bedrijven tijdens algemene informatiebijeenkomst over arbeidsmarkt: } \\
\mathrm{Ja}\end{array}$ & 1,193 & 0,596 \\
\hline In contact met bedrijven tijdens activiteit gericht op sollicitatieprocedure: Ja & 1,033 & 0,938 \\
\hline In contact met bedrijven tijdens deelname aan carrièredagen Ja & 0,996 & 0,992 \\
\hline In contact met bedrijven tijdens activiteit gericht op op te richten eigen bedrijf: Ja & 0,755 & 0,629 \\
\hline Bereid om te verhuizen voor functie: Nee & ref. & \\
\hline Bereid om te verhuizen voor functie: Regionaal & 0,984 & 0,936 \\
\hline Bereid om te verhuizen voor functie: Landelijk & 1,121 & 0,635 \\
\hline Bereid om te verhuizen voor functie: Overall & 1,509 & 0,056 \\
\hline Bereid om te verhuizen voor functie: onbekend & 0,200 & 0,043 \\
\hline Self Efficacy & 0,825 & 0,031 \\
\hline Intrinsiek & 1,070 & 0,351 \\
\hline Extrinsiek & 1,098 & 0,133 \\
\hline
\end{tabular}




\begin{tabular}{|l|r|r|}
\hline Samenwerken met anderen: standpunten van anderen meenemen & 1,034 & 0,764 \\
\hline Samenwerken met anderen: eigen standpunten meenemen & 0,804 & 0,035 \\
\hline Drive & 0,695 & 0,010 \\
\hline Kanaal gebruikt om werk te vinden - Geen, ik kreeg een baan aangeboden & 1,249 & 0,482 \\
\hline Kanaal gebruikt om werk te vinden - Vrienden/familie & 1,928 & 0,000 \\
\hline Kanaal gebruikt om werk te vinden - Contacten van de onderwijsinstelling & 1,557 & 0,051 \\
\hline Kanaal gebruikt om werk te vinden - Contacten van studie/studentenverenigingen & 1,161 & 0,623 \\
\hline Kanaal gebruikt om werk te vinden - Contacten bij een gelopen stage & 0,958 & 0,824 \\
\hline Kanaal gebruikt om werk te vinden - Contacten van bijbaantjes & 0,925 & 0,740 \\
\hline Kanaal gebruikt om werk te vinden - Werving-, uitzend- en selectiebureaus & 1,921 & 0,001 \\
\hline Kanaal gebruikt om werk te vinden - Vacaturewebsites op internet & 1,260 & 0,291 \\
\hline Kanaal gebruikt om werk te vinden - Advertenties in kranten & 1,041 & 0,883 \\
\hline Kanaal gebruikt om werk te vinden - Advertenties in vakbladen & 1,021 & 0,946 \\
\hline Kanaal gebruikt om werk te vinden - Gericht gezocht op websites van bedrijven & 1,021 & 0,913 \\
\hline Kanaal gebruikt om werk te vinden - Banenbeurs/carrièrebeurs & 0,748 & 0,354 \\
\hline Kanaal gebruikt om werk te vinden - Centrum Werk en Inkomen & 1,865 & 0,073 \\
\hline Kanaal gebruikt om werk te vinden - Anders & 2,131 & 0,003 \\
\hline Kanaal gebruikt om werk te vinden - onbekend & 13,309 & 0,001 \\
\hline Constant & 0,044 & 0,004 \\
\hline Bron: & & \\
\hline
\end{tabular}

Bron: HBO Monitor, vervolgonderzoek (ROA) 


\section{Bijlage 5: Hoe vonden respondenten stage en werk?}

In het onderstaand schema valt af te lezen op welke wijze de respondenten een 'succesvolle' sollicitatie hebben gedaan, die leidde tot een stage of werk.

\section{Tabel B.4}

Hoe hebben respondenten hun stage(s) gevonden

\begin{tabular}{|c|c|c|}
\hline \multirow[t]{2}{*}{ Zoekmethode } & \multicolumn{2}{|c|}{$\begin{array}{l}\text { Succesvolle stage match in percentages per } \\
\text { respondenten groep }\end{array}$} \\
\hline & $\begin{array}{r}\text { met } \\
\text { migratieachtergrond }\end{array}$ & $\begin{array}{r}\text { zonder } \\
\text { migratieachtergrond }\end{array}$ \\
\hline \multicolumn{3}{|l|}{ Zelfstandig } \\
\hline Eigen netwerk (familie, vrienden en buurt) & 17 & 15 \\
\hline $\begin{array}{l}\text { Online netwerk (Linkedln) of online vacature (o.a. } \\
\text { stagemotor, stagemarkt en Linkedln) }\end{array}$ & 22 & 15 \\
\hline Open sollicitatie & 9 (100\% naar overheid) & 20 (50\% overheid) \\
\hline \multicolumn{3}{|l|}{ Via opleiding } \\
\hline Speed date / bedrijvendag van opleiding & 9 & 15 \\
\hline 'Vacaturebord' opleiding & 11 & 13 \\
\hline Bemiddeling door docent & 2 & 2 \\
\hline Via medestudent, trainee, afgestudeerde & 2 & 5 \\
\hline \multicolumn{3}{|l|}{ Via werk en stage (bemiddeling) } \\
\hline Via vorig stagebedrijf & 15 & 10 \\
\hline Bemiddeling extern (stage)bureau & 9 & 5 \\
\hline Gevonden door recruiter & 4 (advocatenkantoor & \\
\hline
\end{tabular}

Bovenstaand schema toont dat een groter deel van de studenten zonder migratieachtergrond succesvol gebruik maakt van de open sollicitatie en bedrijvendagen dan de studenten met migratieachtergrond. Een overeenkomst tussen de open sollicitatie en de bedrijvendagen is dat de kandidaten zich zelfstandig presenteren, zonder tussenkomst van iemand uit hun netwerk, opleiding, stagebedrijf of externe partijen (bemiddelaar/recruiters).

Hebben de kandidaten eenmaal contact met een bedrijf (bijvoorbeeld via een stage of bijbaan), dan lijkt de kansenongelijkheid te verdwijnen. Een iets hoger percentage van de studenten met een migratieachtergrond liep een tweede stage of kreeg werk bij het stagebedrijf dan studenten zonder migratieachtergrond. ${ }^{21}$ Het onderstaande schema laat zien hoe de hbo-afgestudeerden die deelnamen aan dit onderzoek hun eerste baan na het afstuderen vonden. 
Tabel B.5

Hoe vonden HBO-afgestudeerden hun eerste baan?

\begin{tabular}{|l|r|r|}
\hline & $\begin{array}{r}\text { met } \\
\text { zonder }\end{array}$ & $\begin{array}{r}\text { zongrachtergrond } \\
\text { migratieachtergrond }\end{array}$ \\
\hline Baan aangenomen bij stagebedrijf & 20 & 15 \\
\hline Vacature gevonden online / Linkedln & 10 & 30 \\
\hline Benaderd door recruiter & 10 & 0 \\
\hline Detachering & 40 & 30 \\
\hline Via in company training & 10 & 0 \\
\hline Eigen netwerk & 10 & 0 \\
\hline Betaald voor recruiter & 0 & 15 \\
\hline Open sollicitatie & 0 & 0 \\
\hline
\end{tabular}


